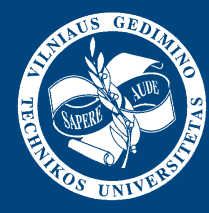

Darius MINIOTAS

\title{
SIGNALAI IR GRANDINĖS
}

Projekto kodas

VP1-2.2-ŠMM-07-K-01-047

Vilnius "Technika" 2012

VGTU Elektronikos fakulteto I pakopos studijų programy esminis atnaujinimas 
VILNIAUS GEDIMINO TECHNIKOS UNIVERSITETAS

Darius MINIOTAS

\section{SIGNALAI IR GRANDINĖS}

Praktinès užduotys ir metodikos nurodymai

Vilnius „Technika“ 2012 
D. Miniotas. Signalai ir grandinès: praktinès užduotys ir metodikos nurodymai. Vilnius: Technika, 2012. 129 p. [4,48 aut. 1.201206 04].

Uždavinyne pateikta žinių apie signalus ir jų apdorojimą tiesinèse stacionario-siose grandinèse, ugdomi gebèjimai analizuoti tokias gran-dines Laplaso ir Furjè transformacijų bei sąsūkos integralo metodais, tam pasitelkiant ir MATLAB ${ }^{\circledR}$ programinę irangą.

Uždavinynas skirtas VGTU Elektronikos fakulteto I pakopos studentams, studijuojantiems „Elektronikos inžinerija“ studiju programoje „ELESB11402 Signalai ir grandinès 1“ bei „ELESB11501 Signalai ir grandinès 2“ dalykus.

Leidinį rekomendavo VGTU Elektronikos fakulteto studijų komitetas

Recenzavo:

doc. dr. Andrius Ušinskas, VGTU Elektroninių sistemų katedra

dr. Dalius Matuzevičius, VGTU Elektroninių sistemų katedra

Leidinys parengtas vykdant projektą „VGTU Elektronikos fakulteto I pakopos studiju programų esminis atnaujinimas". Leidinio rengimą ir leidybą finansavo Vilniaus Gedimino technikos universitetas ir Europos socialinis fondas (sutarties Nr. VP1-2.2-ŠMM-07-K-01-047).

VGTU leidyklos TECHNIKA 1325 -S mokomosios

metodinès literatūros knyga http://leidykla.vgtu.lt

Redaktorè Iruté Raišutienè

Maketuotoja Laura Petrauskiené

eISBN 978-609-457-145-9

doi:10.3846/1325-S

(C) Darius Miniotas, 2012

(C) Vilniaus Gedimino technikos universitetas, 2012 


\section{TURINYS}

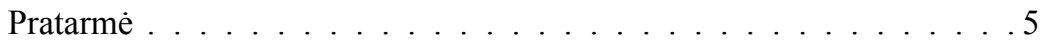

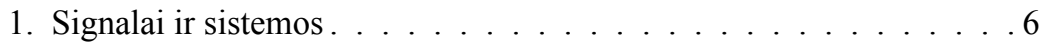

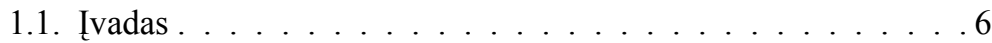

1.2. Signalai ir jų klasifikacija . . . . . . . . . . . . . . 6

1.3. Elementarieji signalai. . . . . . . . . . . . . . . . . . . . . 12

1.4. Sistemos ir jų klasifikacija . . . . . . . . . . . . . . . . . . . . . . . . . . . .

1.5. Uždavinių sprendimo pavyzdžiai . . . . . . . . . . . 23

1.6. Uždaviniai . . . . . . . . . . . . . . . 31

2. Tiesinès stacionariosios sistemos. . . . . . . . . . . . . 39

2.1. Ivadas . . . . . . . . . . . . . . . . . . . 39

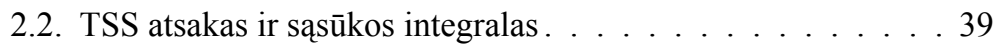

2.3. TSS savybès . . . . . . . . . . . . . . 44

2.4. TSS tikrinès funkcijos . . . . . . . . . . . . . 45

2.5. Sistemų aprašymas diferencialinèmis lygtimis . . . . . . . . 46

2.6. Uždavinių sprendimo pavyzdžiai . . . . . . . . . . . . . . . 49

2.7. Uždaviniai . . . . . . . . . . . . . . . . . . 58

3. Laplaso transformacija ir TSS . . . . . . . . . . . 65

3.1. Ivadas . . . . . . . . . . . . . . . . 65

3.2. Laplaso transformacija . . . . . . . . . . . . . . 65

3.3. Dažnai sutinkamų signalų Laplaso transformacijos . . . . . . 70

3.4. Laplaso transformacijos savybès . . . . . . . . . . . . . . 72

3.5. Atvirkštinè Laplaso transformacija . . . . . . . . . . . . . . 74

3.6. Sistemos funkcija . . . . . . . . . . . . . 76

3.7. Vienpusè Laplaso transformacija . . . . . . . . . . . . . 80

3.8. Uždavinių sprendimo pavyzdžiai. . . . . . . . . . . . . 83

3.9. Uždaviniai . . . . . . . . . . . . . . . . . . 993

4. Spektrinè tolydinių signalų ir sistemų analizè . . . . . . . . . . 101

4.1. Ivadas . . . . . . . . . . . . . . . . . . . 101

4.2. Periodinių signalų vaizdavimas Furjè eilute . . . . . . . . . 101

4.3. Furjè transformacija . . . . . . . . . . . . . 103

4.4. Tolydinès Furjè transformacijos savybès . . . . . . . . 105 
4.5. Dažninès TSS charakteristikos . . . . . . . . . . . . 108

4.6. Uždavinių sprendimo pavyzdžiai. . . . . . . . . . . . . . 109

4.7. Uždaviniai . . . . . . . . . . . . . . . . . . . . 117

Literatūra. . . . . . . . . . . . . . . . . . . . . . . . 129 


\section{PRATARME்}

Signalu ir grandinių (arba sistemų bendruoju atveju) teorijos reikia beveik visose elektros ir elektronikos inžinerijos srityse, taip pat daugelyje kitų inžinerinių ir fundamentinių mokslų. Šios žinios sudaro tolimesnių specializuotų studijų, pavyzdžiui, automatikos ar telekomunikacijų inžinerijos, pagrindą.

Šis uždavinynas skirtas elektronikos inžinerijos studentams, studijuojantiems pirmosios pakopos dalykus „Signalai ir grandinès 1“ bei „Signalai ir grandinès 2“. Uždavinynas sumanytas kaip priedas prie vadovèlių ir mokomujjų knygų, naudojamų studijuojant teorini kursą.

Uždavinyną sudaro keturi skyriai. Pirmajame skyriuje pateikiama signalų ir sistemų klasifikacija kartu su jų matematiniu aprašymu. Antrajame skyriuje apžvelgiami svarbiausi sąryšiai tarp ièjimo ir išèjimo signalų tiesinèse stacionariosiose sistemose, atskleidžiama tokių sistemų impulsinès charakteristikos sąvoka ir sąsūkos operacijos esmè. Trečiajame skyriuje aiškinama, kaip taikyti Laplaso transformaciją nagrinejjant tolydines tiesines stacionariąsias sistemas. Ketvirtasis skyrius skirtas spektrinei tokiu sistemu analizei.

Uždavinynas parengtas taip, kad būtų tinkamas ne tik kaip mokomoji priemonè pratyboms, bet ir praverstų studijuojant savarankiškai. Todèl dauguma uždavinyne pateiktų uždavinių turi atsakymus, kad studentai galètu pasitikrinti gautus rezultatus. Studentų darbui palengvinti kiekviename uždavinyno skyriuje glaustai pateikiama teorinių žinių, reikalingų sprendžiant uždavinius, ir po keletą tipinių uždaviniu sprendimo pavyzdžių. Kai kuriuose iš šių pavyzdžiu parodyta, kaip naudoti MATLAB ${ }^{\circledR}$ paketą sprendžiant uždavinius. Ši informacija turettu ypač praversti išvedant sistemos arba perdavimo funkciją ir braižant dažnines charakteristikas.

Darius Miniotas 


\section{SIGNALAI IR SISTEMOS}

\subsection{Ivadas}

Sąvokų, apibūdinančių signalus ir sistemas, bei su šiomis sąvokomis susijusios teorijos reikia beveik visoms elektros inžinerijos sritims, taip pat daugeliui kitų taikomujų ir fundamentinių mokslu disciplinų. Šiame skyriuje matematiškai aprašomi signalai ir sistemos bei pateikiama jų klasifikacija. Be to, apibrèžiama keletas svarbių elementariųjų signalų, būtinų tolimesnèms studijoms.

\subsection{Signalai ir jų klasifikacija}

Signalu vadinama funkcija, vaizduojanti fizikinị dydị arba kintamąji, kuri perduoda informaciją apie tam tikro reiškinio eigą arba pobūdì. Pavyzdžiui, $R C$ grandinèje signalu gali būti įtampa ant kondensatoriaus plokštelių arba rezistoriumi tekanti srové. Matematiškai signalas vaizduojamas nepriklausomo kintamojo $t$, kuris paprastai išreiškia laiką, funkcija $x(t)$.

\section{Tolydiniai ir diskretinamojo laiko signalai}

Signalas $x(t)$ vadinamas tolydiniu, jei $t$-tolydinis kintamasis. Jei $t$-diskretusis kintamasis (t. y. $x(t)$ apibrèžta tik diskrečiais laiko momentais), tuomet $x(t)$ vadinamas diskretinamojo laiko signalu. Kadangi diskretinamojo laiko signalas apibrěžtas diskrečiais laiko momentais, jis dažnai tapatinamas su skaičiu seka $x(n)$, kurioje $n$ - sveikasis skaičius. Tolydinio signalo pavyzdys pateiktas 1.1 a pav., o diskretinamojo laiko signalo - 1.1 b pav. Šiame uždavinyne diskretinamojo laiko signalai nebus nagrinèjami. 


\section{Analoginiai ir skaitmeniniai signalai}

Jei tolydinis signalas $x(t)$ gali turèti bet kurią verte, priklausančią tolydžiajam intervalui $(a, b)$, kuriame $a$ gali būti $-\infty$, o $b$ gali būti $+\infty$, jis vadinamas analoginiu. Jei diskretinamojo laiko signalas $x(n)$ gali turèti tik baigtini verčiu skaičių, jis vadinamas skaitmeniniu.

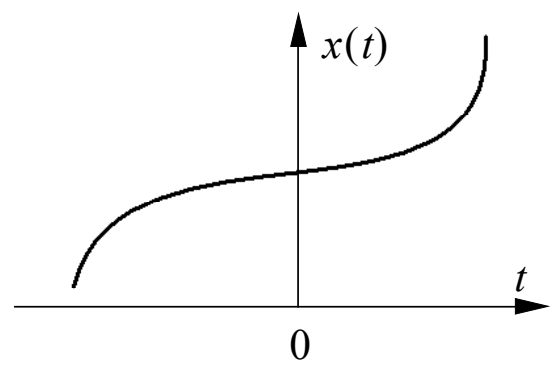

a)

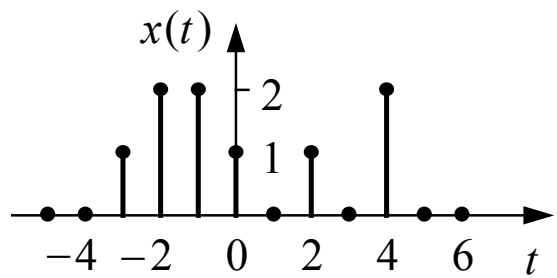

b)

1.1 pav. Tolydinis (a) ir diskretinamojo laiko (b) signalai

\section{Realieji ir kompleksiniai signalai}

Signalas $x(t)$ yra realusis, jei jo verte - realusis skaičius. Kita vertus, jei signalo verte - kompleksinis skaičius, toks signalas vadi- 
namas kompleksiniu. Bendruoju atveju kompleksinis signalas $x(t)$ yra tokios išraiškos funkcija:

$$
x(t)=x_{1}(t)+j x_{2}(t)
$$

čia $x_{1}(t)$ ir $x_{2}(t)$ - realieji signalai, o $j=\sqrt{-1}$.

\section{Determinuotieji ir atsitiktiniai signalai}

Determinuotaisiais signalais vadinami tokie, kurių visos vertès apibrèžtos bet kuriuo laiko momentu. Taigi determinuotaji signalą galima modeliuoti žinoma laiko $t$ funkcija. Atsitiktiniais signalais vadinami tokie, kurių vertès bet kuriuo laiko momentu - atsitiktiniai skaičiai. Tokie signalai apibūdinami statistiškai. Šiame uždavinyne atsitiktiniai signalai nebus nagrinejjami.

\section{Lyginiai ir nelyginiai signalai}

Signalas $x(t)$ vadinamas lyginiu, jei

$$
x(-t)=x(t) .
$$

Signalas $x(t)$ vadinamas nelyginiu, jei

$$
x(-t)=-x(t)
$$

Lyginio signalo pavyzdys pateiktas 1.2 a pav., o nelyginio $1.2 \mathrm{~b}$ pav.

Bet kurị signalą $x(t)$ galima išreikšti dviejų signalų, iš kurių vienas - lyginis, o kitas - nelyginis, suma, t. $\mathrm{y}$. 


$$
x(t)=x_{l}(t)+x_{n}(t)
$$

čia $\quad x_{l}(t)=\frac{1}{2}[x(t)+x(-t)]$ lyginè $x(t)$ dalis,

$$
x_{n}(t)=\frac{1}{2}[x(t)-x(-t)] \text { nelyginè } x(t) \text { dalis. }
$$

Pažymėtina, kad dviejų lyginių arba dviejų nelyginių signalų sandauga yra lyginis signalas, o lyginio ir nelyginio signalų sandauga - nelyginis signalas.
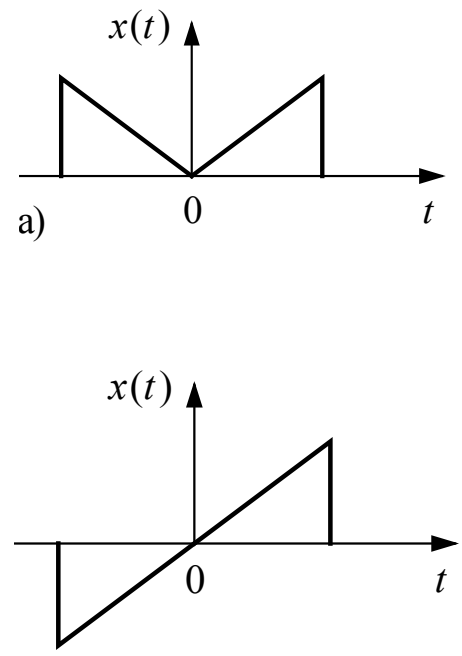

b)

1.2 pav. Lyginis (a) ir nelyginis (b) signalai 


\section{Periodiniai ir neperiodiniai signalai}

Tolydinis signalas $x(t)$ vadinamas periodiniu signalu, kurio periodas $-T$, jei egzistuoja teigiama nenulinè $T$ vertè, kuriai galioja

$$
x(t+T)=x(t) \quad \text { visoms } t .
$$

Tokio signalo pavyzdys pateiktas 1.3 pav. Iš (1.5) matyti, kad

$$
x(t+m T)=x(t)
$$

visoms $t$ vertems ir bet kuriam sveikajam skaičiui $m$. Pagrindiniu $x(t)$ periodu $T_{0}$ laikoma mažiausia teigiama $T$ vertè, kuriai galioja (1.5) lygybė. Pažymètina, kad šis apibrèžimas negalioja pastoviajam signalui $x(t)$ (žinomam kaip nuolatinès srovès signalas). Tokiam signalui pagrindinis periodas neapibrèžtas, nes $x(t)$ - periodinis, esant bet kokiam $T$ (todèl nebūna mažiausios teigiamos vertès). Bet kuris tolydinis signalas, kuris nèra periodinis, vadinamas neperiodiniu (arba aperiodiniu) signalu.

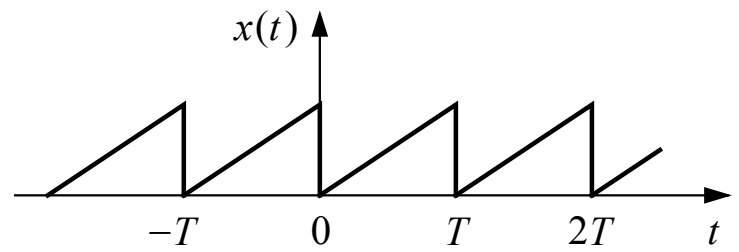

1.3 pav. Periodinis signalas

Pažymètina, kad dviejų tolydinių periodinių signalų suma gali būti ir neperiodinis signalas (1.13 uždavinys). 


\section{Energijos ir galios signalai}

Tarkime, $\operatorname{kad} v(t)$ - itampos kritimas ant rezistoriaus $R$, lemiantis srovę $i(t)$, Vienam omui tenkanti momentinè galia $p(t)$ apibrèžiama taip:

$$
p(t)=\frac{v(t) i(t)}{R}=i^{2}(t) .
$$

Vienam omui tenkanti pilnutinè energija $E$ ir vidutinè galia $P$ atitinkamai lygios:

$$
\begin{gathered}
E=\int_{-\infty}^{\infty} i^{2}(t) d t \quad[\mathrm{~J}], \\
P=\lim _{T \rightarrow \infty} \frac{1}{T} \int_{-T / 2}^{T / 2} i^{2}(t) d t \quad[\mathrm{~W}] .
\end{gathered}
$$

Bet kokiam tolydiniam signalui $x(t)$ jo normuotoji energija apibrežiama taip:

$$
E=\int_{-\infty}^{\infty}|x(\mathrm{t})|^{2} d t .
$$

Bet kokiam tolydiniam signalui $x(t)$ jo normuotoji vidutinè galia apibrěžiama taip:

$$
P=\lim _{T \rightarrow \infty} \frac{1}{T} \int_{-T / 2}^{T / 2}|x(t)|^{2} d t .
$$

Remiantis (1.10) ir (1.11) išraiškomis, apibrèžiamos tokios signalų klasès:

1. $x(t)$ vadinamas energijos signalu tada ir tik tada, kai $0<E<\infty$, todèl $P=0$.

2. $x(t)$ vadinamas galios signalu tada ir tik tada, kai $0<P<\infty$.

O tai reiškia, $\operatorname{kad} E=\infty$. 
3. Nei vienos iš šiu savybiu netenkinantys signalai priskiriami signalų, nepriklausančių nei energijos, nei galios signalams, klasei.

Pažymètina, kad periodinis signalas priklauso galios signalų klasei, jei periodo ribose jo energija yra baigtinè. Tuomet vidutinei šio signalo galiai rasti pakanka skaičiuoti vieną periodą.

\subsection{Elementarieji signalai}

\section{Vienetinè laiptinė funkcija}

Vienetinẻ laiptinè funkcija $u(t)$, dar žinoma kaip Hevisaido funkcija, apibrèžiama taip:

$$
u(t)=\left\{\begin{array}{ll}
1 & t>0 \\
0 & t<0
\end{array} .\right.
$$

Ši funkcija pavaizduota 1.4 a pav. Iš funkcijos grafiko matyti, kad ji turi trūkị laiko momentu $t=0$. Kitaip tariant, funkcijos vertè momentu $t=0$ yra neapibrěžta. Panašiai apibrèžiama ir perstumta vienetinè laiptinè funkcija $u\left(t-t_{0}\right)$ :

$$
u\left(t-t_{0}\right)=\left\{\begin{array}{ll}
1 & t>t_{0} \\
0 & t<t_{0}
\end{array} .\right.
$$

Šios funkcijos grafikas pateiktas $1.4 \mathrm{~b}$ pav. 


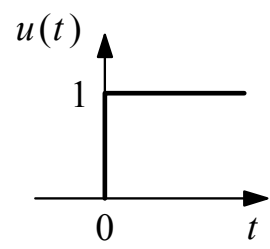

a)

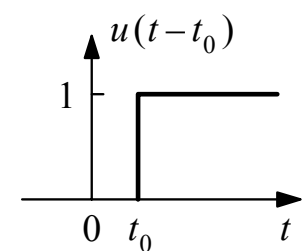

b)

1.4 pav. Vienetinė laiptinè (a) ir perstumta vienetinè laiptinè (b) funkcijos

\section{Vienetinė impulsinė funkcija}

Vienetinè impulsinė funkcija $\delta(t)$, dar žinoma kaip delta (Dirako) funkcija, atlieka svarbų vaidmeni analizuojant sistemas. Ji apibrèžiama taip:

$$
\delta(t)=\left\{\begin{array}{ll}
0 & t \neq 0 \\
\infty & t=0
\end{array} .\right.
$$

Ši funkcija unikali tuo, kad jos plotas be galo mažame laiko intervale lygus 1. Matematiškai ši savybė užrašoma taip:

$$
\int_{-\infty}^{\infty} \delta(t) d t=1
$$

Vienetinę impulsinę funkciją grafiškai priimta vaizduoti, kaip parodyta 1.5 a pav.

Perstumta vienetinė impulsinė funkcija $\delta\left(t-t_{0}\right)$ apibrèžiama taip:

$$
\delta\left(t-t_{0}\right)=\left\{\begin{array}{ll}
0 & t \neq t_{0} \\
\infty & t=t_{0}
\end{array} .\right.
$$


Šios funkcijos grafikas pateiktas $1.5 \mathrm{~b}$ pav.

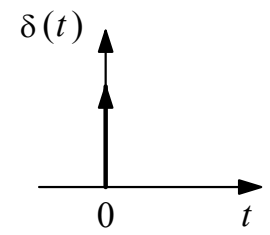

a)

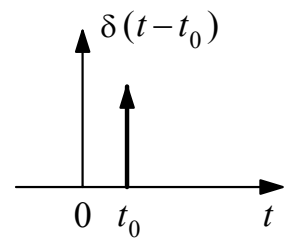

b)

1.5 pav. Vienetinė impulsinè (a) ir perstumta vienetinè impulsinė (b) funkcijos

Vienetinei impulsinei funkcijai būdingos dar šios savybės:

$$
\begin{gathered}
\delta(a t)=\frac{1}{|a|} \delta(t), \\
\delta(-t)=\delta(t), \\
x(t) \delta(t)=x(0) \delta(t),
\end{gathered}
$$

jei $x(t)$ tolydi momentu $t=0$.

$$
x(t) \delta\left(t-t_{0}\right)=x\left(t_{0}\right) \delta\left(t-t_{0}\right)
$$

jei $x(t)$ tolydi momentu $t=t_{0}$.

Remiantis vienetinès impulsinès funkcijos savybėmis, galima irodyti, kad bet kuriam tolydiniam signalui $x(t)$ galioja tokia lygybè:

$$
x(t)=\int_{-\infty}^{\infty} x(\tau) \delta(t-\tau) d \tau .
$$




\section{Kompleksinės eksponentès signalai}

Svarbus kompleksinio signalo pavyzdys yra kompleksinès eksponentės signalas:

$$
x(t)=e^{j \omega_{0} t} .
$$

Naudojant Eulerio formulę, šị signalą galima apibrèžti taip:

$$
x(t)=e^{j \omega_{0} t}=\cos \omega_{0} t+j \sin \omega_{0} t .
$$

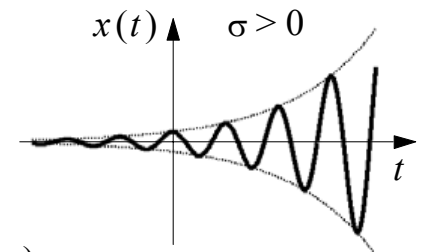

a)

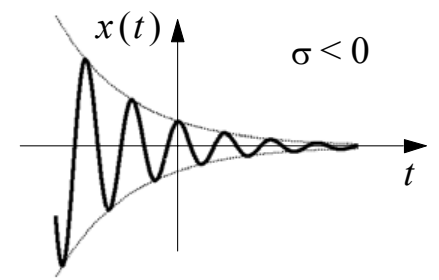

b)

1.6 pav. Eksponentiškai didejjantis (a) ir mažèjantis (b) sinusiniai signalai

Taigi $x(t)$ - tai kompleksinis signalas, turintis realiąją dali $\cos \omega_{0} t$ ir menamają dali sin $\omega_{0} t$. Svarbi kompleksinès eksponentès signalo savybė yra jo periodiškumas. Pagrindinis $x(t)$ periodas $T_{0}$ apibrèžiamas taip (1.11 uždavinys): 


$$
T_{0}=\frac{2 \pi}{\omega_{0}} .
$$

Pažymėtina, kad $x(t)$ būna periodinis, esant bet kuriai $\omega_{0}$ vertei.

Tarkime, kad duotas kompleksinis skaičius $s=\sigma+j \omega$. Apibrèžkime $x(t)$ kaip

$$
x(t)=e^{s t}=e^{(\sigma+j \omega) t}=e^{\sigma t}(\cos \omega t+j \sin \omega t) .
$$

Toks signalas vadinamas bendriniu kompleksinès eksponentès signalu. Jo realioji dalis $e^{\sigma t} \cos \omega t$ ir menamoji dalis $e^{\sigma t} \sin \omega t$ yra eksponentiškai didejjantys $(\sigma>0)$ arba mažèjantys $(\sigma<0)$ sinusiniai signalai (1.6 pav.).

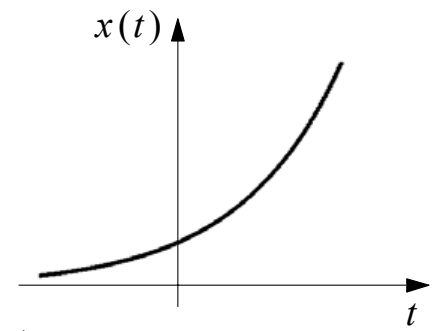

a)

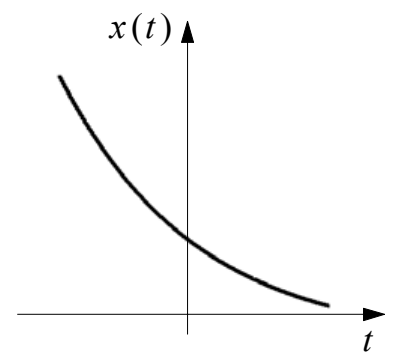

b)

1.7 pav. Realieji eksponentiniai signalai, kai (a) $\sigma>0$ ir (b) $\sigma<0$ 
Jei $s=\sigma$ (realusis skaičius), (1.25) lygybė aprašo realujji eksponentinị signalą

$$
x(t)=e^{\sigma t} .
$$

Kaip matyti iš 1.7 pav., $x(t)$ yra didejanti eksponente, jei $\sigma>0$. Kita vertus, jei $\sigma<0, x(t)$ - mažèjanti eksponentè.

\section{Sinusiniai signalai}

Sinusinị signalą galima užrašyti taip:

$$
x(t)=A \cos \left(\omega_{0} t+\theta\right),
$$

čia: $A$ - amplitudè (realusis skaičius), $\omega_{0}$ - kampinis dažnis radianais per sekundę, $\theta$ - fazès kampas radianais. Sinusinis signalas $x(t)$ yra periodinis, jo pagrindinis periodas:

$$
T_{0}=\frac{2 \pi}{\omega_{0}} .
$$

Šis signalas $x(t)$ pavaizduotas 1.8 pav. Pagrindiniam periodui $T_{0}$ atvirkščias dydis vadinamas pagrindiniu dažniu $f_{0}$ :

$$
f_{0}=\frac{1}{T_{0}} \quad \mathrm{~Hz} .
$$

Remiantis (1.28) ir (1.29) lygybèmis,

$$
\omega_{0}=2 \pi f_{0} .
$$

Šis dydis vadinamas pagrindiniu kampiniu dažniu. Naudojant Eulerio formulę, (1.27) lygybę galima perrašyti taip:

$$
A \cos \left(\omega_{0} t+\theta\right)=A \operatorname{Re}\left\{e^{j\left(\omega_{0} t+\theta\right)}\right\} .
$$


Tuomet

$$
A \operatorname{Im}\left\{e^{j\left(\omega_{0} t+\theta\right)}\right\}=A \sin \left(\omega_{0} t+\theta\right) .
$$

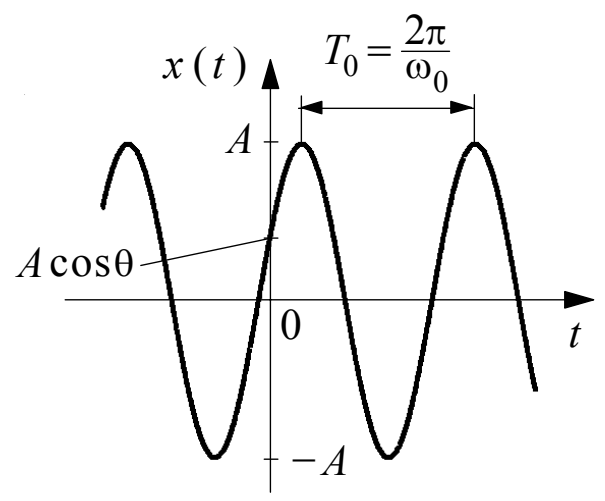

1.8 pav. Sinusinis signalas

\subsection{Sistemos ir jų klasifikacija}

\section{Sistemų vaizdavimas}

Sistema - tai matematinis fizinio proceso modelis, susiejantis tarpusavyje iejjimo (arba žadinimo) ir išèjimo (arba atsako) signalus.

Tarkime, kad $x$ ir $y$ yra atitinkamai sistemos iejjimo ir išèjimo signalai. Tuomet sistemą galima traktuoti kaip $x$ transformavimą $i$ $y$. Ši transformacija matematiškai užrašoma taip:

$$
y=\mathbf{T} x,
$$

čia $\mathbf{T}$ - operatorius, aprašantis tam tikrą gerai apibrèžtą taisyklę, pagal kurią $x$ transformuojamas i $y$. (1.33) sąryšis grafiškai pavaizduotas 1.9 a pav. Bendruoju atveju sistema gali turèti keletą iejjimo ir (arba) išèjimo signalų, kaip parodyta 1.9 b pav. Tačiau šiame už- 
davinyne apsiribosime paprasčiausiomis sistemomis, turinčiomis tik vieną ièjimą ir vieną išèjima.

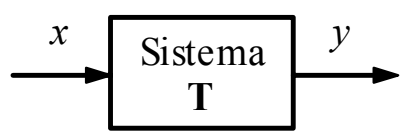

a)

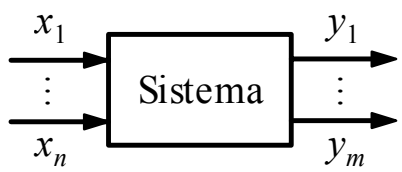

b)

1.9 pav. Sistema su vienu (a) arba keletu (b) iejjimo ir išejimo signalu

\section{Tolydžiojo ir diskretinamojo laiko sistemos}

Jei įejimo ir išèjimo signalai $x$ ir $y$ yra tolydiniai signalai, tokia sistema vadinama tolydžiojo laiko (tolydine) sistema (1.10 a pav.). Jei ièjimo ir išejimo signalai yra diskretinamojo laiko signalai (sekos), tokia sistema vadinama diskretinamojo laiko sistema (1.10 b pav.).

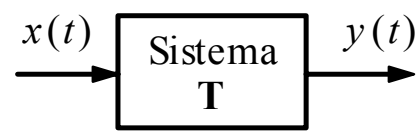

a)

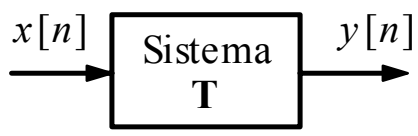

b)

1.10 pav. Tolydžiojo laiko (a) ir diskretinamojo laiko (b) sistemos

\section{Statinès ir dinaminès sistemos}

Sistema laikoma statine, jei jos išèjimo signalas bet kuriuo laiko momentu priklauso tik nuo įèjimo signalo vertès tuo pačiu laiko 
momentu. Priešingu atveju sistema yra dinaminè. Statinès sistemos pavyzdys - rezistorius $R$, kurio iejjimo signalu $x(t)$ laikoma srovè, o išèjimo signalu $y(t)$ - ittampa. Sąryši tarp rezistoriaus iejjimo ir išèjimo signalų nusako Omo dèsnis:

$$
y(t)=R x(t) .
$$

Dinaminès sistemos pavyzdys - kondensatorius $C$, kurio įejimo signalu $x(t)$ laikoma srovè, o išèjimo signalu $y(t)$ - įtampa. Tuomet

$$
y(t)=\frac{1}{C} \int_{-\infty}^{t} x(\tau) d \tau .
$$

\section{Priežastinès ir nepriežastinės sistemos}

Sistema vadinama priežastine, jei jos išèjimo signalas $y(t)$ bet kuriuo laiko momentu $t=t_{0}$ priklauso tik nuo iejjimo signalo $x(t)$ verčių, atitinkančių intervalą $t \leq t_{0}$. Kitaip tariant, priežastinès sistemos išèjimos signalas esamuoju momentu priklauso tik nuo iejjimo signalo verčių esamuoju ir (arba) ankstesniaisiais laiko momentais, bet ne nuo jo verčių ateityje. Taigi esant priežastinei sistemai išèjimo signalas negali atsirasti anksčiau nei i ją paduodamas iejjimo signalas. Priešingu atveju sistema yra nepriežastinè. Nepriežastinès sistemos pavyzdys:

$$
y(t)=x(t+1) .
$$

Pažymètina, kad visos statinès sistemos yra priežastinès. O priešingas teiginys negalioja. 


\section{Tiesinès ir netiesinès sistemos}

Jei (1.33) lygtyje nurodytas operatorius $\mathbf{T}$ tenkina toliau suformuluotas adityvumo ir homogeniškumo sąlygas, jis vadinamas tiesiniu operatoriumi, o tokiu operatoriumi vaizduojama sistema - tiesine sistema.

Adityvumas: jei teisingos lygybès $\mathbf{T} x_{1}=y_{1}$ ir $\mathbf{T} x_{2}=y_{2}$, tai bet kokiems signalams $x_{1}$ ir $x_{2}$ galioja:

$$
\mathbf{T}\left\{x_{1}+x_{2}\right\}=y_{1}+y_{2} .
$$

Homogeniškumas: bet kokiam signalui $x$ ir bet kokiam skaliarui $\alpha$ galioja:

$$
\mathbf{T}\{\alpha x\}=\alpha y .
$$

Bet kuri sistema, netenkinanti kurios nors iš pastarujų dviejų lygčių, laikoma netiesine. (1.36) ir (1.37) lygtis galima sujungti $\mathfrak{i}$ vieną sąlygą:

$$
\mathbf{T}\left\{\alpha_{1} x_{1}+\alpha_{2} x_{2}\right\}=\alpha_{1} y_{1}+\alpha_{2} y_{2},
$$

čia $\alpha_{1}$ ir $\alpha_{2}$ - bet kokie skaliarai. (1.38) lygtis dar žinoma kaip superpozicijos savybè. Tiesiniu sistemu pavyzdžiai - rezistorius [(1.34) lygtis] ir kondensatorius [(1.35) lygtis]. Netiesiniu sistemu pavyzdžiai:

$$
\begin{gathered}
y=x^{2}, \\
y=\cos x .
\end{gathered}
$$


Tiesinių sistemų homogeniškumo savybė lemia, kad nulinis ièjimo signalas sąlygoja nulini išèjimo signalą. Tai yra dar viena svarbi tiesinių sistemų savybè.

\section{Stacionariosios ir nestacionariosios sistemos}

Sistema vadinama stacionariaja, jei jos iejjimo signalo postūmis tam tikru laiku (vèlinimas arba ankstinimas) lemia tokị paṭ̨ išèjimo signalo postūmi. Matematiniu požiūriu sistema yra stacionarioji, jei bet kuriai realiajai $\tau$ vertei galioja:

$$
\mathbf{T}\{x(t-\tau)\}=y(t-\tau) .
$$

Sistema, netenkinanti (1.41) lygties, vadinama nestacionariaja. Norint patikrinti sistemos stacionarumą, galima palyginti perstumtą išèjimo signalą su išèjimo signalu, kuri lemia perstumto ieejimo signalas (1.4 ir 1.5 uždaviniai).

\section{Stabiliosios sistemos}

Sistema yra stabilioji, jei bet kokị apribotaji iejjimo signalą $x$, apibrěžiamą kaip

$$
|x| \leq k_{1},
$$

atitinka apribotasis išèjimo signalas

$$
|y| \leq k_{2},
$$

čia $k_{1}$ ir $k_{2}$ - baigtinès realiosios konstantos. 


\section{Sistemos su grị̌tamuoju ryšiu}

Šios sistemos yra labai svarbios ir priklauso atskirai sistemu klasei. Sistemos su grižtamuoju ryšiu išejimo signalas grąžinamas i ièjimą ir pridedamas prie sistemos iejjimo signalo, kaip pavaizduota 1.11 pav.

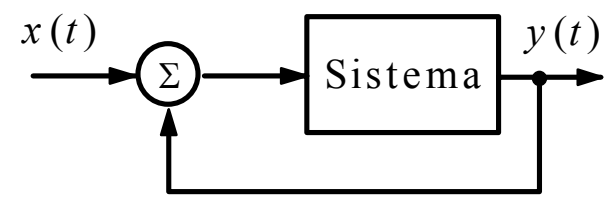

1.11 pav. Sistema su grižtamuoju ryšiu

\subsection{Uždavinių sprendimo pavyzdžiai}

1.1. Nustatykite, kuriai kategorijai priklauso šie signalai: energijos signalų, galios signalų ar nei vienų, nei kitų.

(a) $x(t)=e^{-a t} u(t), \quad a>0$;

(b) $x(t)=A \cos \left(\omega_{0} t+\theta\right)$;

(c) $x(t)=t u(t)$.

\section{Sprendimas}

(a) $E=\int_{-\infty}^{\infty}|x(t)|^{2} d t=\int_{0}^{\infty} e^{-2 a t} d t=\frac{1}{2 a}<\infty$.

Taigi $x(t)$ yra energijos signalas.

(b) Sinusinis signalas $x(t)$ yra periodinis, nes turi perioda $T_{0}=2 \pi / \omega_{0}$. Vidutinè $x(t)$ galia skaičiuojama taip: 


$$
\begin{gathered}
P=\frac{1}{T_{0}} \int_{0}^{T_{0}}[x(t)]^{2} d t=\frac{\omega_{0}}{2 \pi} \int_{0}^{2 \pi / \omega_{0}} A^{2} \cos ^{2}\left(\omega_{0} t+\theta\right) d t \\
=\frac{A^{2} \omega_{0}}{2 \pi} \int_{0}^{2 \pi / \omega_{0}} \frac{1}{2}\left[1+\cos \left(2 \omega_{0} t+2 \theta\right)\right] d t=\frac{A^{2}}{2}<\infty .
\end{gathered}
$$

Taigi $x(t)$ - galios signalas. Dera atminti, kad visi periodiniai signalai yra galios signalai.

$$
\begin{gathered}
\text { (c) } E=\lim _{T \rightarrow \infty} \int_{-T / 2}^{T / 2}|x(t)|^{2} d t=\lim _{T \rightarrow \infty} \int_{0}^{T / 2} t^{2} d t=\lim _{T \rightarrow \infty} \frac{(T / 2)^{3}}{3}=\infty, \\
P=\lim _{T \rightarrow \infty} \frac{1}{T} \int_{-T / 2}^{T / 2}|x(t)|^{2} d t=\lim _{T \rightarrow \infty} \frac{1}{T} \int_{0}^{T / 2} t^{2} d t \\
=\lim _{T \rightarrow \infty} \frac{1}{T} \frac{(T / 2)^{3}}{3}=\infty .
\end{gathered}
$$

Taigi $x(t)$ nèra nei energijos, nei galios signalas.

1.2. Raskite pirmąsias šių signalų išvestines ir nubraižykite jų grafikus:

(a) $x(t)=u(t)-u(t-a), \quad a>0$;

(b) $x(t)=t[u(t)-u(t-a)], \quad a>0$;

(c) $x(t)=\left\{\begin{array}{ll}1, & t>0 \\ -1, & t<0\end{array}\right.$.

\section{Sprendimas}

(a) Kadangi $u^{\prime}(t)=\delta(t)$, tai $u^{\prime}(t-a)=\delta(t-a)$. Tuomet

$$
x^{\prime}(t)=u^{\prime}(t)-u^{\prime}(t-a)=\delta(t)-\delta(t-a) .
$$


Signalai $x(t)$ ir $x^{\prime}(t)$ pavaizduoti 1.12a pav..
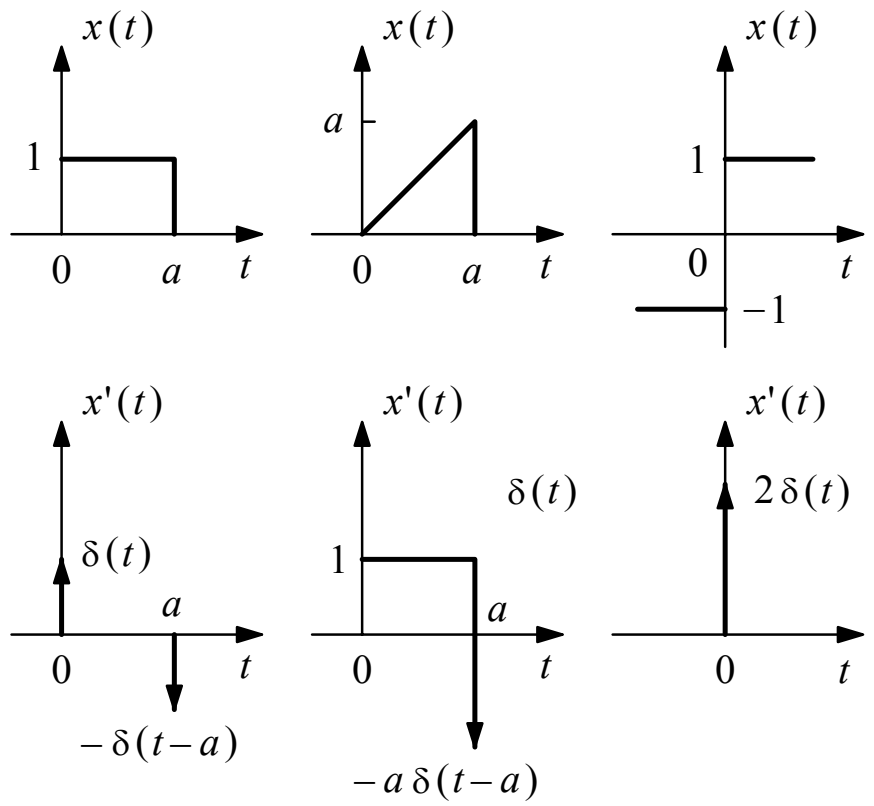

a)

b)

c)

\subsection{2 pav.}

(b) Pasinaudojus dviejų funkcijų sandaugos diferencijavimo savybe ir (a) dalyje gautu rezultatu, galima užrašyti:

$$
x^{\prime}(t)=[u(t)-u(t-a)]+t[\delta(t)-\delta(t-a)] .
$$

Tačiau remiantis (1.19) ir (1.20) lygtimis,

$$
t \delta(t)=(0) \delta(t)=0, \quad t \delta(t-a)=a \delta(t-a) .
$$

Taigi

$$
\left.x^{\prime}(t)=u(t)-u(t-a)-a \delta(t-a)\right]
$$


Signalai $x(t)$ ir $x^{\prime}(t)$ pavaizduoti $1.12 \mathrm{~b}$ pav.

(c) Signalą $x(t)$ galima perrašyti taip:

$$
x(t)=u(t)-u(-t) .
$$

Tuomet

$$
x^{\prime}(t)=u^{\prime}(t)-u^{\prime}(-t)=\delta(t)-[-\delta(t)]=2 \delta(t) .
$$

Signalai $x(t)$ ir $x^{\prime}(t)$ pavaizduoti $1.12 \mathrm{c}$ pav.

1.3. Raskite sąryši tarp 1.13 pav. pavaizduotos $R C$ grandinès iejjimo signalo $x(t)$ ir išèjimo signalo $y(t)$, jei:

(a) $x(t)=v_{S}(t), \quad y(t)=v_{c}(t)$;

(b) $x(t)=v_{S}(t), \quad y(t)=i(t)$.

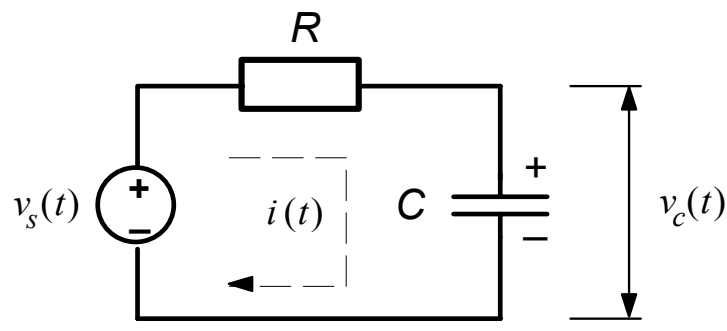

1.13 pav.

\section{Sprendimas}

(a) Pritaikius antrajji Kirchhofo dėsni 1.13 pav. pavaizduotai $R C$ grandinei, galima užrašyti: 


$$
v_{S}(t)=R i(t)+v_{c}(t) .
$$

Srovė $i(t)$ ir įtampa $v_{c}(t)$ susietos sąryšiu:

$$
i(t)=C \frac{d v_{c}(t)}{d t}
$$

Užrašius tapatybes $v_{s}(t)=x(t), v_{c}(t)=y(t)$ ir istačius (1.45) lygti i (1.44),

$$
R C \frac{d y(t)}{d t}+y(t)=x(t)
$$

Tai galima perrašyti taip:

$$
\frac{d y(t)}{d t}+\frac{1}{R C} y(t)=\frac{1}{R C} x(t) .
$$

Taigi šios $R C$ grandinès išèjimo signalo priklausomybę nuo įèjimo signalo aprašo pirmosios eilès tiesinè diferencialinè lygtis su pastoviaisiais koeficientais.

(b) Integruojant (1.45) lygti,

$$
v_{c}(t)=\frac{1}{C} \int_{-\infty}^{t} i(\tau) d \tau .
$$

Istačius (1.47) lygti i (1.44) ir užrašius tapatybes $v_{S}(t)=x(t)$, $i(t)=y(t)$, gaunama tokia išraiška:

$$
R y(t)+\frac{1}{C} \int_{-\infty}^{t} y(\tau) d \tau=x(t)
$$

Tai galima perrašyti taip:

$$
y(t)+\frac{1}{R C} \int_{-\infty}^{t} y(\tau) d \tau=\frac{1}{R} x(t) .
$$


Diferencijuojant abi šios lygties puses laiko atžvilgiu,

$$
\frac{d y(t)}{d t}+\frac{1}{R C} y(t)=\frac{1}{R} \frac{d x(t)}{d t} .
$$

Kaip matome, išèjimo signalo priklausomybę nuo iejjimo signalo aprašo kita pirmosios eilès tiesinè diferencialinė lygtis su pastoviaisiais koeficientais.

1.4. Tarkime, kad 1.14 pav. pavaizduoto kondensatoriaus iejjimo signalas $x(t)=i(t)$, o išèjimo signalas $y(t)=v_{c}(t)$.

(a) Raskite sąryšş tarp ièjimo ir išèjimo signalų.

(b) Nustatykite, ar sistema yra: dinaminè, priežastinè, tiesinè, stacionarioji, stabilioji.

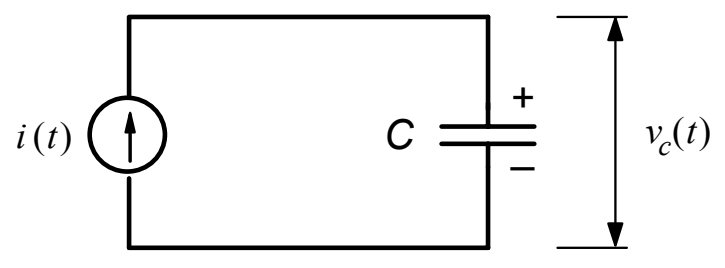

1.14 pav.

\section{Sprendimas}

(a) Laikykime, kad kondensatoriaus talpa $C$ - pastovus dydis. Kondensatoriaus išèjimo signalas $y(t)$ ir iejjimo signalas $x(t)$ susieti (1.47) lygtimi:

$$
y(t)=\mathbf{T}\left\{x(t)=\frac{1}{C} \int_{-\infty}^{t} x(\tau) d \tau .\right.
$$

(b) Iš (1.49) lygties matyti, kad išèjimo signalas $y(t)$ priklauso nuo esamosios ir ankstesniujju iejjimo signalo verčių. Taigi ši sistema yra dinaminè. Kadangi išèjimo signalas $y(t)$ nepriklauso nuo būsimujų iẹjimo signalo verčių, sistema yra priežastinè.

Tarkime, $\operatorname{kad} x(t)=\alpha_{1} x_{1}(t)+\alpha_{2} x_{2}(t)$. Tuomet 


$$
\begin{gathered}
y(t)=\mathbf{T}\{x(t)\}=\frac{1}{C} \int_{-\infty}^{t}\left[\alpha_{1} x_{1}(\tau)+\alpha_{2} x_{2}(\tau)\right] d \tau \\
=\alpha_{1}\left[\frac{1}{C} \int_{-\infty}^{t} x_{1}(\tau) d \tau\right]+\alpha_{2}\left[\frac{1}{C} \int_{-\infty}^{t} x_{2}(\tau) d \tau\right]=\alpha_{1} y_{1}(t)+\alpha_{2} y_{2}(t) .
\end{gathered}
$$

Kadangi superpozicijos savybė (1.38) tenkinama, sistema yra tiesinè.

Tarkime, kad $y_{1}(t)$ yra išèjimo signalas, kurị lemia perstumto iejjimo signalas $x_{1}(t)=x\left(t-t_{0}\right)$. Tuomet

$$
\begin{aligned}
y_{1}(t) & =\mathbf{T}\left\{x\left(t-t_{0}\right)\right\}=\frac{1}{C} \int_{-\infty}^{t} x\left(\tau-t_{0}\right) d \tau \\
& =\frac{1}{C} \int_{-\infty}^{t-t_{0}} x(\lambda) d \lambda=y\left(t-t_{0}\right) .
\end{aligned}
$$

Taigi sistema yra stacionarioji.

Tarkime, $\operatorname{kad} x(t)=k_{1} u(t)$, kai $k_{1} \neq 0$. Tuomet

$$
y(t)=\frac{1}{C} \int_{-\infty}^{t} k_{1} u(\tau) d \tau=\frac{k_{1}}{C} \int_{0}^{t} d \tau=\frac{k_{1}}{C} t u(t) .
$$

Kaip matyti iš šios funkcijos grafiko (1.15 pav.), laikui bègant $y(t)$ didejja tiesiškai be apribojimo. Todèl sistema nèra stabilioji. 


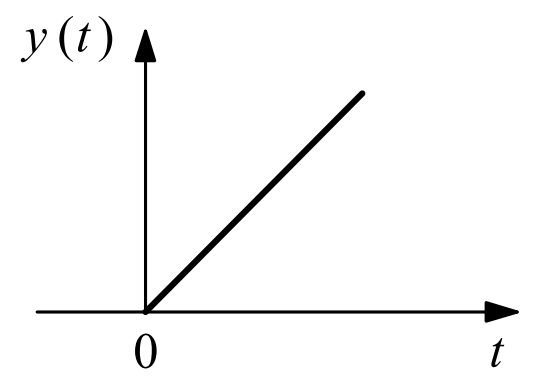

1.15 pav.

1.5. Nustatykite, ar 1.16 pav. pavaizduota sistema yra: (a) dinaminè, (b) priežastinè, (c) tiesinè, (d) stacionarioji, (e) stabilioji.

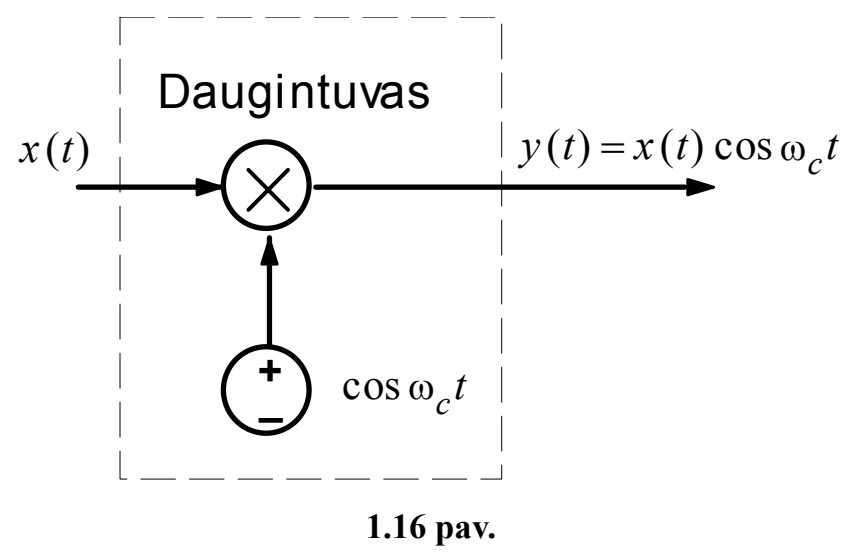

(a) Iš 1.16 pav. matyti, kad:

$$
y(t)=\mathbf{T}\{x(t)\}=x(t) \cos \omega_{c} t .
$$

Kadangi išęjimo signalo $y(t)$ vertè priklauso tik nuo iejjimo signalo $x(t)$ vertẻs esamuoju momentu, sistema nèra dinaminè. 
(b) Kadangi išèjimo signalas $y(t)$ nepriklauso nuo būsimuju iejjimo signalo verčiu, sistema yra priežastinè.

(c) Tarkime, $\operatorname{kad} x(t)=\alpha_{1} x_{1}(t)+\alpha_{2} x_{2}(t)$ Tuomet

$$
\begin{gathered}
y(t)=\mathbf{T}\{x(t)\}=\left[\alpha_{1} x_{1}(t)+\alpha_{2} x_{2}(t)\right] \cos \omega_{c} t \\
=\alpha_{1} x_{1}(t) \cos \omega_{c} t+\alpha_{2} x_{2}(t) \cos \omega_{c} t=\alpha_{1} y_{1}(t)+\alpha_{2} y_{2}(t) .
\end{gathered}
$$

Kadangi superpozicijos savybė (1.38) tenkinama, sistema yra tiesinè.

(d) Tarkime, kad $y_{1}(t)$ yra išèjimo signalas, kurị lemia perstumto iejejimo signalas $x_{1}(t)=x\left(t-t_{0}\right)$. Tuomet

$$
y_{1}(t)=\mathbf{T}\left\{x\left(t-t_{0}\right)\right\}=x\left(t-t_{0}\right) \cos \omega_{c} t .
$$

Tačiau

$$
y\left(t-t_{0}\right)=x\left(t-t_{0}\right) \cos \omega_{c}\left(t-t_{0}\right) \neq y_{1}(t) .
$$

Taigi sistema nèra stacionarioji.

(e) Kadangi $\left|\cos \omega_{c} t\right| \leq 1$, galima užrašyti:

$$
|y(t)|=\left|x(t) \cos \omega_{c} t\right| \leq|x(t)| .
$$

Taigi, esant apribotam ièjimo signalui $x(t)$, išèjimo signalas $y(t)$ irgi yra apribotas. Todèl sistema yra stabilioji.

\subsection{Uždaviniai}

1.6. 1.17 pav. pavaizduotas tolydinis signalas $x(t)$. Nubrèžkite šiu signalu grafikus: (a) $x(t-2)$; (b) $x(2 t)$; (c) $x(t / 2)$; (d) $x(-t)$. Ats. Žr. 1.18 pav. 


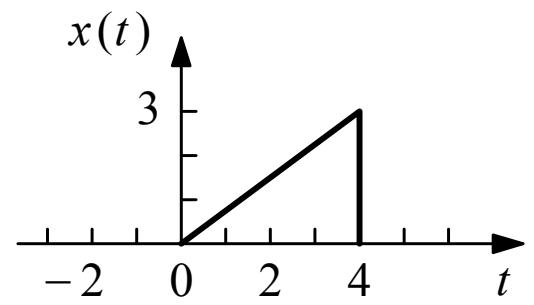

1.17 pav.

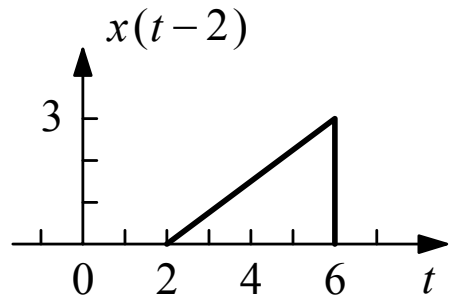

a)

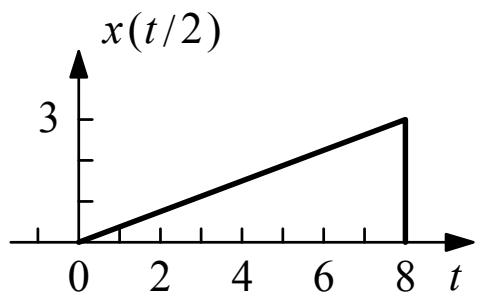

c)

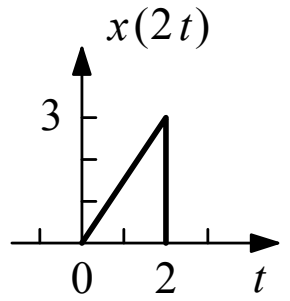

b)

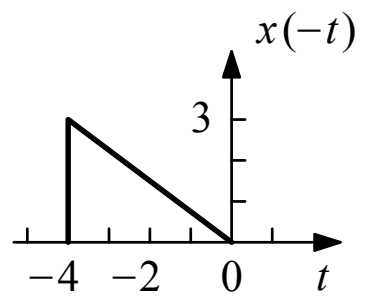

d)

1.18 pav.

1.7. Nubraižykite nelygines ir lygines 1.19 pav. pavaizduoto signalo dedamąsias. Ats. Žr. 1.20 pav. 


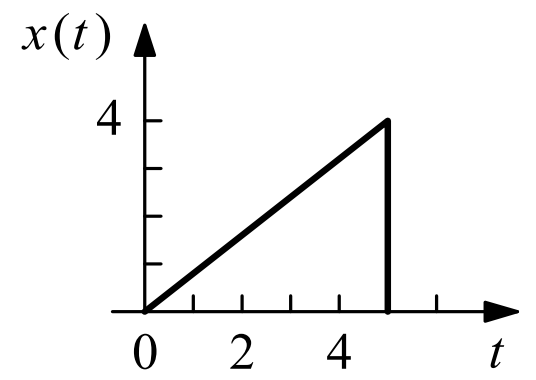

1.19 pav.
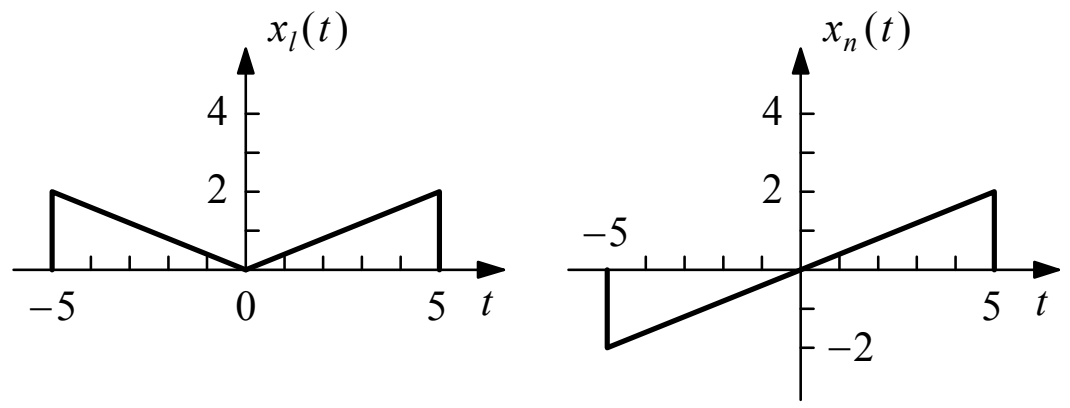

1.20 pav.

1.8. Raskite signalo $x(t)=e^{j t}$ lyginę ir nelyginę dedamąsias. Ats. $x_{l}(t)=\cos t, x_{n}(t)=j \sin t$.

1.9. Irodykite, kad dviejų lyginių arba dviejų nelyginių signalų sandauga yra lyginis signalas, o nelyginio ir lyginio signalų sandauga - nelyginis signalas.

1.10. Irodykite, kad lyginiam signalui $x(t)$ galioja:

$$
\int_{-a}^{a} x(t) d t=2 \int_{0}^{a} x(t) d t,
$$

o nelyginiam signalui - 


$$
\int_{-a}^{a} x(t) d t=0
$$

1.11. Irodykite, kad kompleksinès eksponentès signalas

$$
x(t)=e^{j \omega_{0} t}
$$

yra periodiné funkcija, kurios periodas lygus $2 \pi / \omega_{0}$.

1.12. Irodykite, kad sinusinis signalas

$$
x(t)=\cos \left(\omega_{0} t+\theta\right)
$$

yra periodinè funkcija, kurios periodas lygus $2 \pi / \omega_{0}$.

1.13. Tarkime, $\operatorname{kad} x_{1}(t)$ ir $x_{2}(t)$ yra periodiniai signalai, kuriu periodai atitinkamai lygūs $T_{1}$ ir $T_{2}$. Kokiomis sąlygomis šių signalų suma $x(t)=x_{1}(t)+x_{2}(t)$ irgi yra periodinis signalas? Jei $x(t)$ - periodinis, koks yra jo periodas?

1.14. Nustatykite, ar šie signalai yra periodiniai, ir jei taip, raskite jų periodą.
(a) $x(t)=\cos \left(t+\frac{\pi}{4}\right)$
(b) $x(t)=\sin \frac{2 \pi}{3} t$;
(c) $x(t)=\cos \frac{\pi}{3} t+\sin \frac{\pi}{4} t$
(d) $x(t)=\cos t+\sin \sqrt{2} t$;
(e) $x(t)=\sin ^{2} t$
(f) $x(t)=e^{j[(\pi / 2) t-1]}$. 
Ats. (a) periodinis, $T_{0}=2 \pi$; (b) periodinis, $T_{0}=3$;

(c) periodinis, $T_{0}=24$; (d) neperiodinis;

(e) periodinis, $T_{0}=\pi$; $\quad$ (f) periodinis, $T_{0}=4$.

1.15. Irodykite, kad signalui, kuriam galioja $x(t+T)=x(t)$, teisingos ir šios dvi lygybès:

$$
\begin{aligned}
& \int_{\alpha}^{\beta} x(t) d t=\int_{\alpha+T}^{\beta+T} x(t) d t \\
& \int_{0}^{T} x(t) d t=\int_{0}^{a+T} x(t) d t .
\end{aligned}
$$

Čia $\alpha, \beta$ ir $a-$ bet kokie realieji skaičiai.

1.16. Irodykite, kad

$$
u(-t)=\left\{\begin{array}{ll}
0, & t>0 \\
1, & t<0
\end{array}\right. \text {. }
$$

1.17. 1.21 pav. pavaizduotas tolydinis signalas $x(t)$. Nubrèžkite šių signalų grafikus:

(a) $x(t) u(1-t)$;

(b) $x(t)[u(t)-u(t-1)]$;

(c) $x(t) \delta\left(t-\frac{3}{2}\right)$. 


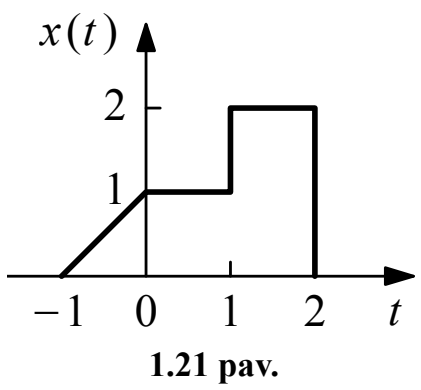

1.18. Vienetinio šuolio funkciją $u(t)$ galima apibrèžti kaip apibendrintą funkciją, naudojant toki sąryšį:

$$
\int_{-\infty}^{\infty} \phi(t) u(t) d t=\int_{0}^{\infty} \phi(t) d t,
$$

čia $\phi(t)$ - pagalbinė funkcija, integruojama intervale $0<t<\infty$. Naudodami ší apibrèžimą, ịrodykite, kad

$$
u(-t)= \begin{cases}1, & t>0 \\ 0, & t<0 .\end{cases}
$$

1.19. Irodykite, kad

(a) $\delta(a t)=\frac{1}{|a|} \delta(t)$

(b) $\delta(-t)=\delta(t)$.

1.20. Irodykite, kad

$$
x(t) \delta\left(t-t_{0}\right)=x\left(t_{0}\right) \delta\left(t-t_{0}\right)
$$

jei $x(t)$ yra tolydi taške $t=t_{0}$. 
1.21. Irodykite, kad

$x(t) \delta(t)=x(0) \delta(t)$,

jei $x(t)$ yra tolydi taške $t=0$.

1.22. Irodykite, kad

(a) $t \delta(t)=0$;

(b) $\sin t \delta(t)=0$;

(c) $\cos t \delta(t-\pi)=-\delta(t-\pi)$.

1.23. Irodykite, kad

(a) $\delta(t)=u^{\prime}(t)=\frac{d u(t)}{d(t)}$.

1.24. Irodykite, $\operatorname{kad} \delta(t)$ išvestinei galioja šios savybès:

(a) $\int_{-\infty}^{\infty} \phi(t) \delta^{\prime}(\mathrm{t}) d t=-\phi^{\prime}(0)$,

čia $\phi^{\prime}(0)=\left.\frac{d \phi(t)}{d t}\right|_{t=0} ;$

(b) $t \delta^{\prime}(t)=-\delta(t)$.

1.25. Apskaičiuokite šiuos integralus:
(a) $\int_{-1}^{1}\left(3 t^{2}+1\right) \delta(t) d t$;
(b) $\int_{1}^{2}\left(3 t^{2}+1\right) \delta(t) d t$; 

(c) $\int_{-\infty}^{\infty}\left(t^{2}+\cos \pi t\right) \delta(t-1) d t$;
(d) $\int_{-1}^{1} e^{-t} \delta(2 t-2) d t$;
(e) $\int_{-1}^{1} e^{-t} \delta^{\prime}(t) d t$.
Ats. (a) $1 ; \quad$ (b) $0 ; \quad$ (c) $0 ; \quad$ (d) $\frac{1}{2 e}$; (e) 1 .

1.26. Turime sistemą, kurios iejjimo ir išèjimo signalai susieti tokiu sąryšiu:

$$
y=\mathbf{T}\{x\}=x^{2} .
$$

Irodykite, kad tokia sistema yra netiesinè.

1.27. (a) Irodykite, kad tolydinès tiesinès sistemos priežastingumo savybè patvirtina tokị teiginị: bet kokiam ièjimo signalui $x(t)$, kuriam bet kuriuo laiko momentu galioja $x(t)=0$, kai $t \leq t_{0}$, išèjimo signalas $y(t)$ irgi lygus nuliui, kai $t \leq t_{0}$.

(b) Pateikite pavyzdị netiesinės sistemos, kuri būtų priežastinè, tačiau netenkintų minètos sąlygos.

(c) Pateikite pavyzdị netiesinès sistemos, kuri tenkintų minètą sąlygą, tačiau nebūtų priežastinè.

1.28. Tarkime, kad $\mathbf{T}$ išreiškia tolydinę tiesinę stacionariąją sistema. Irodykite, kad tokiai sistemai galioja:

$$
\mathbf{T}\left\{e^{s t}\right\}=\lambda e^{s t},
$$

čia $s$ - kompleksinis kintamasis, $\lambda$ - kompleksinè konstanta. 


\section{TIESINĖS STACIONARIOSIOS SISTEMOS}

\subsection{Ivadas}

Dvi pačios svarbiausios sistemų savybės yra jų tiesiškumas ir stacionarumas. Šiame skyriuje aptarsime, kaip randamas šiomis savybėmis pasižyminčiu sistemų atsakas i žžnomos formos i̇ëjimo signalą. Kaip matysime, TSS atsako priklausomybę nuo jos iejjime veikiančio signalo apibūdina sąsūkos operacija. Šios operacijos svarbą lemia tai, kad, žinant TSS atsaką i vienetinę impulsinę funkciją, galima rasti tokios sistemos atsaką i bet kokị iejjimo signalą. Šiame skyriuje taip pat aptarsime, kaip naudoti diferencialines lygtis sąryšiams tarp TSS įejjimo ir išèjimo signalų aprašyti.

\subsection{TSS atsakas ir sąsūkos integralas}

\section{Impulsinė charakteristika}

Impulsinè tolydinès TSS (vaizduojamos operatoriumi T) charakteristika $h(t)$ apibrěžiama kaip sistemos atsakas ị vienetinę impulsinę funkciją:

$$
h(t)=\mathbf{T}\{\delta(t)\} .
$$

\section{Atsakas ị bet kokị iẹjimo signalą}

Remiantis (1.21) lygtimi, iẻjimo signalą $x(t)$ galima užrašyti taip: 


$$
x(t)=\int_{-\infty}^{\infty} x(\tau) \delta(t-\tau) d \tau .
$$

Kadangi sistema tiesinè, jos atsaką $y(t)$ i bet koki iejjimo signalą galima aprašyti taip:

$$
\begin{gathered}
y(t)=\mathbf{T}\{x(t)\}=\mathbf{T}\left\{\int_{-\infty}^{\infty} x(\tau) \delta(t-\tau) d \tau\right\} \\
\int_{-\infty}^{\infty} x(\tau) \mathbf{T}\{\delta(t-\tau)\} d \tau .
\end{gathered}
$$

Kadangi sistema stacionarioji, galima užrašyti:

$$
h(t-\tau)=\mathbf{T}\{\delta(t-\tau)\} .
$$

Istačius (2.4) lygti i (2.3),

$$
y(t)=\int_{-\infty}^{\infty} x(\tau) h(t-\tau) d \tau
$$

Kaip rodo (2.5) lygtis, tolydinę TSS visiškai apibūdina jos impulsinè charakteristika $h(t)$.

\section{Sąsūkos integralas}

(2.5) lygtis apibrèžia dviejų tolydinių signalų $x(t)$ ir $h(t)$ sąsūką, žymimą žvaigždutès simboliu:

$$
y(t)=x(t) * h(t)=\int_{-\infty}^{\infty} x(\tau) h(t-\tau) d \tau .
$$


(2.6) lygtị priimta vadinti sąsūkos integralu. Taigi gavome labai svarbų rezultatą: bet kokios tolydinès TSS išèjimo signalas - tai iejjimo signalo $x(t)$ ir sistemos impulsinès charakteristikos $h(t)$ sąsūka. Ši impulsinès charakteristikos $h(t)$ apibrèžimą ir (2.6) lygtimi aprašomą sąryšị vaizduoja 2.1 pav.

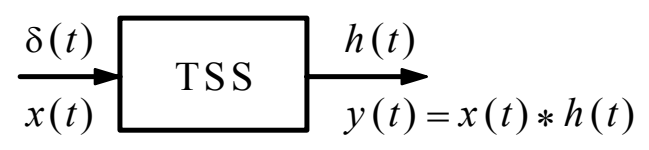

2.1 pav. Tolydinè tiesinè stacionarioji sistema

\section{Sąsūkos integralo savybės}

Sąūūos integralui būdingos tokios savybès:

- perstatomumas

$$
x(t) * h(t)=h(t) * x(t),
$$

- jungiamumas

$$
\left\{x(t) * h_{1}(t)\right\} * h_{2}(t)=x(t) *\left\{h_{1}(t) * h_{2}(t)\right\},
$$

- skirstomumas

$$
x(t) *\left\{h_{1}(t)+h_{2}(t)\right\}=x(t) * h_{1}(t)+x(t) * h_{2}(t) .
$$

\section{Sąsūkos integralo operacija}

Pritaikius perstatomumo savybę 2.6 lygčiai,

$$
y(t)=h(t) * x(t)=\int_{-\infty}^{\infty} h(\tau) x(t-\tau) d \tau
$$


Kartais ši integralą būna lengviau apskaičiuoti nei tą, kuris aprašomas 2.6 lygtimi. Iš pastarosios lygties matyti, kad sąsūkos integralo operaciją sudaro keturi etapai:

1. Impulsinè charakteristika $h(\tau)$ apverčiama tam tikru laiku (t. y. apgręžiama koordinačiu pradžios atžvilgiu), taip gaunant $h(-\tau)$

Šią perstūmus intervalu $t$, gaunama $h(t-\tau)=h[-(\tau-t)]$, kuri yra $\tau$ funkcija su parametru $t$.

2. Signalas $x(\tau)$ ir $h(t-\tau)$ dauginami visoms $\tau$ vertėms, esant fiksuotai $t$ vertei.

3. Sandauga $x(\tau) h(t-\tau)$ integruojama visame $\tau$ verčiu diapazone, taip gaunant vieną išèjimo signalo $y(t)$ vertę.

4. Norint gauti visas išèjimo signalo $y(t)$ vertes, pirmieji trys etapai kartojami, $t$ kintant nuo $-\infty$ iki $\infty$.

Aprašytają sąsūkos integralo operaciją iliustruojantys pavyzdžiai pateikti 2.1, 2.9 ir 2.10 uždaviniuose.

\section{Šuolinis atsakas}

Tolydinès TSS šuolinis atsakas $s(t)$ - tai sistemos atsakas i ièjimo signalą $u(t)$ :

$$
s(t)=\mathbf{T}\{u(t)\}
$$

Atliekant daugelị taikymų šuolinis atsakas $s(t)$ irgi būna naudingas sistemai apibūdinti. Šuolinį atsaką nesunku rasti iš (2.10) lygties:

$$
s(t)=h(t) * u(t)=\int_{-\infty}^{\infty} h(\tau) u(t-\tau) d \tau=\int_{-\infty}^{t} h(\tau) d \tau .
$$

Taigi šuolini atsaką $s(t)$ galima rasti integruojant impulsinę charakteristiką $h(t)$. Diferencijuojant (2.12) lygtị laiko atžvilgiu, 


$$
h(t)=s^{\prime}(t)=\frac{d s(t)}{d t} .
$$

Tokiu būdu impulsinę charakteristiką $h(t)$ galima rasti diferencijuojant šuolinị atsaką.

\subsection{TSS savybès \\ Statinès ir dinaminès sistemos}

Kadangi statinès sistemos išęjimo signalas $y(t)$ priklauso tik nuo ièjimo signalo $x(t)$ vertès esamuoju momentu, tai TSS atveju šis sąryšis gali būti tik toks:

$$
y(t)=K x(t),
$$

čia $K$ - konstanta. Taigi impulsinè charakteristika $h(t)$ atitinkamai lygi:

$$
h(t)=K \delta(t) .
$$

Todèl, jei $h\left(t_{0}\right) \neq 0$, kai $t_{0} \neq 0$, tolydinè TSS yra dinaminè.

\section{Priežastingumas}

Kaip jau buvo aptarta 1.4 poskyryje, priežastinè sistema nereaguoja ị kokị nors ịvyki savo iẹjime tol, kol tas įvykis iš tikruju neįvyksta. Todèl priežastinei tolydinei TSS galioja:

$$
h(t)=0, \quad t<0 .
$$


(2.10) lygčiai pritaikius priežastingumo sąlygą (2.16), priežastinès tolydinès TSS išèjimo signalas išreiškiamas taip:

$$
y(t)=\int_{0}^{\infty} h(\tau) x(t-\tau) d \tau .
$$

O pritaikius priežastingumo sąlygą (2.6) lygčiai, gaunama:

$$
y(t)=\int_{-\infty}^{t} x(\tau) h(t-\tau) d \tau .
$$

Kaip matyti iš (2.18) lygties, išèjimo signalui $y(t)$ rasti reikalingos tik tos ièjimo signalo $x(t)$ vertès, kurioms galioja nelygybè: $\tau \leq t$.

Remiantis priežastingumo sąlyga (2.16), bet koks signalas $x(t)$ vadinamas priežastiniu, jei

$$
x(t)=0, \quad t<0 .
$$

O jei

$$
x(t)=0, \quad t>0,
$$

signalas $x(t)$ vadinamas antipriežastiniu. Remiantis (2.17), (2.18) ir (2.19a) lygtimis, priežastinès tolydinès TSS išẻjimo signalas $y(t)$ aprašomas taip:

$$
y(t)=\int_{0}^{t} h(\tau) x(t-\tau) d \tau=\int_{0}^{t} x(\tau) h(t-\tau) d \tau .
$$




\section{Stabilumas}

Tuo, kad TSS yra stabilioji, nesunkiai galima isitikinti panagrinëjus jos impulsinę charakteristiką. Tarkime, kad tolydinès TSS ¡èjimo signalas $x(t)$ yra apribotas

$$
|x(t)| \leq k_{1} \quad \text { visiems } t .
$$

Tuomet, pasinaudojus (2.10) lygtimi, galima užrašyti:

$$
\begin{aligned}
|y(t)| & =\left|\int_{-\infty}^{\infty} h(\tau) x(t-\tau) d \tau\right| \leq \int_{-\infty}^{\infty}|h(\tau) x(t-\tau)| d \tau \\
& =\int_{-\infty}^{\infty}|h(\tau)||x(t-\tau)| d \tau \leq k_{1} \int_{-\infty}^{\infty}|h(\tau)| d \tau .
\end{aligned}
$$

Taigi, jei impulsinè charakteristika absoliučiai integruojama:

$$
\int_{-\infty}^{\infty}|h(\tau)| d \tau=K<\infty
$$

tai $|y(t)| \leq k_{1} K=k_{2}$, kas įrodo sistemos stabilumą.

\subsection{TSS tikrinès funkcijos}

Kaip buvo aptarta pirmajame skyriuje, tikrinès TSS funkcijos yra kompleksinès eksponentès $e^{\text {st }}$ :

$$
\mathbf{T}\left\{e^{s t}\right\}=\lambda e^{s t},
$$

čia $\lambda-$ tikrinè $\mathbf{T}$ vertè, susijusi su $e^{s t}$. I (2.10) lygti irašius $x(t)=e^{s t}$, 


$$
\begin{gathered}
y(t)=\mathbf{T}\left\{e^{s t}\right\}=\int_{-\infty}^{\infty} h(\tau) e^{s(t-\tau)} d \tau=\left[\int_{-\infty}^{\infty} h(\tau) e^{-s \tau} d \tau\right] e^{s t} \\
=H(s) e^{s t}=\lambda e^{s t}
\end{gathered}
$$

čia

$$
\lambda=H(s)=\int_{-\infty}^{\infty} h(\tau) e^{-s \tau} d \tau .
$$

Taigi TSS tikrinę vertę, susijusią su tikrine funkcija $e^{s t}$, aprašo $H(s)$ - kompleksinè konstanta, kurios vertę lemia kompleksinio kintamojo $s$ vertè. Iš (2.23) lygties taip pat išeina, kad $y(0)=H(s)$.

Gautieji rezultatai sudaro Laplaso ir Furjè transformaciju apibrèžimų, pateiktų trečiajame ir ketvirtajame šio uždavinyno skyriuose, pagrindą.

\subsection{Sistemų aprašymas diferencialinėmis lygtimis}

\section{Tiesinès diferencialinès lygtys su pastoviaisiais koeficientais}

Bendroji $n$-osios eilès tiesinè diferencialinè lygtis su pastoviaisiais koeficientais yra tokia:

$$
\sum_{k=0}^{N} a_{k} \frac{d^{k} y(t)}{d t^{k}}=\sum_{k=0}^{M} b_{k} \frac{d^{k} x(t)}{d t^{k}},
$$

čia koeficientai $a_{k}$ ir $b_{k}$ - realieji skaičiai. o-oji eilè nusako aukščiausią $y(t)$ išvestinę (2.25) lygtyje. Tokioms diferencialinėms lygtims tenka pagrindinis vaidmuo aprašant ịvairiausių elektrinių, mechaninių, cheminių ir biologinių sistemų sąryšius tarp iejjimo ir išèjimo signalų. Pavyzdžiui, 1.3 uždavinyje nagrinètoje $R C$ grandinèje ièjimo signalas $x(t)=v_{s}(t)$ ir išèjimo signalas $y(t)=v_{c}(t)$ 
tarpusavyje susieti šia pirmosios eilès diferencialine lygtimi (1.46) su pastoviaisiais koeficientais:

$$
\frac{d y(t)}{d t}+\frac{1}{R C} y(t)=\frac{1}{R C} x(t) .
$$

Bendrasis (2.25) lygties sprendinys duotam iejjimo signalui $x(t)$ užrašomas taip:

$$
y(t)=y_{d}(t)+y_{b}(t),
$$

čia $y_{d}(t)$ - dalinis sprendinys, tenkinantis (2.25) lygti, o $y_{b}(t)-$ bendrasis sprendinys, tenkinantis homogeninę diferencialinę lygtị:

$$
\sum_{k=0}^{N} a_{k} \frac{d^{k} y(t)}{d t^{k}}=0 .
$$

Tikslią $y_{b}(t)$ išraišką lemia $N$ pagalbinių sąlygų. Pažymėtina, kad (2.25) lygtis iki galo nenusako išèjimo signalo $y(t)$ priklausomybès nuo įejimo signalo $x(t)$, jei nenurodytos pagalbinès sąlygos. Bendruoju atveju pagalbinių sąlygų sistemą sudaro funkcijų

$$
y(t), \frac{d y(t)}{d t}, \ldots, \frac{d^{N-1} y(t)}{d t^{N-1}}
$$

vertès nurodytu laiko momentu.

\section{Tiesiškumas}

(2.25) lygtimi aprašoma sistema bus tiesinė tik tuomet, kai visos pagalbinès sąlygos bus lygios nuliui (žr. 2.19 uždavini). Jei pagalbinès sąlygos nelygios nuliui, sistemos reakciją $y(t)$ galima užrašyti taip:

$$
y(t)=y_{n s}(t)+y_{n p}(t),
$$


čia $y_{n s}(t)$ - sistemos reakcija, esant nuliniam iejjimo signalui, o $y_{n p}(t)$ - sistemos reakcija, esant nulinėms pagalbinėms sąlygoms. (2.28) lygtis grafiškai pavaizduota 2.2 pav.

Pažymètina, kad $y_{n s}(t) \neq y_{b}(t)$, o $y_{n p}(t) \neq y_{d}(t)$, kadangi bendruoju atveju i $y_{n s}(t)$ sudeti ieina $y_{b}(t)$, o $y_{n p}(t)$ susideda tiek iš $y_{b}(t)$, tiek ir iš $y_{d}(t)$ (žr. 2.5 uždavini $)$.

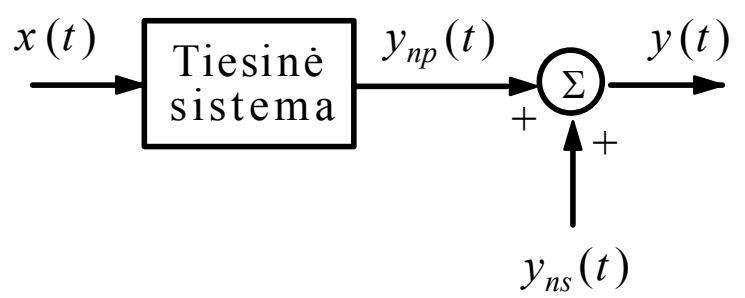

2.2 pav. Sistemos reakcija, esant nuliniam ièjimo signalui ir nulinèms pagalbinèms sąlygoms

\section{Priežastingumas}

Tam, kad (2.25) lygtimi aprašoma tiesinė sistema būtų priežastinè, privalu daryti prielaidą apie pradinę ramybès būseną, $\mathrm{t}$. y. jei $x(t)=0$, esant $t \leq t_{0}$, tai laikoma, $\operatorname{kad} y(t)=0$, esant $t \leq t_{0}$ (žr. 1.27 uždavini). Taigi, kai $t>t_{0}$, sistemos reakcija galima apskaičiuoti iš (2.25) lygties, esant tokioms pradinèms sąlygoms:

$$
y\left(t_{0}\right)=\frac{d y\left(t_{0}\right)}{d t}=\cdots=\frac{d^{N-1} y\left(t_{0}\right)}{d t^{N-1}}=0,
$$

čia

$$
\frac{d^{k} y\left(t_{0}\right)}{d t^{k}}=\left.\frac{d^{k} y(t)}{d t^{k}}\right|_{t=t_{0}}
$$


Akivaizdu, kad esant pradinei ramybès būsenai $y_{n s}(t)=0$.

\section{Stacionarumas}

Esant tiesinei priežastinei sistemai pradinė pusiausvyros būsena kartu reiškia ir stacionarumą (2.20 uždavinys).

\section{Impulsinė charakteristika}

Tolydinès TSS, aprašomos (2.25) lygtimi, impulsinè charakteristika $h(t)$ tenkina diferencialinę lygti

$$
\sum_{k=0}^{N} a_{k} \frac{d^{k} h(t)}{d t^{k}}=\sum_{k=0}^{M} b_{k} \frac{d^{k} \delta(t)}{d t^{k}},
$$

esant pradinei ramybės būsenai. Pavyzdžiai, kaip randama impulsinė charakteristika, - 2.21-2.23 uždaviniai. Trečiajame ir ketvirtajame skyriuose impulsinès charakteristikos ieškosime, taikydami transformacijų metodus.

\subsection{Uždavinių sprendimo pavyzdžiai}

2.1. Tolydinès tiesinès stacionariosios sistemos iejimo signalas $x(t)$ ir impulsinè charakteristika $h(t)$ aprašomi taip:

$$
x(t)=u(t) \quad h(t)=e^{-\alpha t} u(t), \quad \alpha>0 .
$$

(a) Apskaičiuokite išèjimo signalą $y(t)$, naudodami (2.6) lygti.

(b) Apskaičiuokite išèjimo signalą $y(t)$, naudodami (2.10) lygti. 


\section{Sprendimas}

(a) Remiantis (2.6) lygtimi,

$$
y(t)=x(t) * h(t)=\int_{-\infty}^{\infty} x(\tau) h(t-\tau) d \tau .
$$

Funkcijos $x(\tau)$ ir $h(t-\tau)$ pavaizduotos 2.3 a pav., kai $t<0$ ir $t>0$. Kaip matyti iš šio paveikslo, kai $t<0, x(\tau)$ ir $h(t-\tau)$ nepersidengia. O kai $t>0$, funkcijos persidengia intervale nuo $\tau=0 \mathrm{iki}$ $\tau=t$. Todèl, kai $t<0, y(t)=0$. Kai $t>0$, sistemos atsakas lygus:

$$
\begin{gathered}
y(t)=\int_{0}^{t} e^{-\alpha(t-\tau)} d \tau=e^{-\alpha t} \int_{0}^{t} e^{\alpha \tau} d \tau \\
=e^{-\alpha t} \frac{1}{\alpha}\left(e^{\alpha t}-1\right)=\frac{1}{\alpha}\left(1-e^{-\alpha t}\right) .
\end{gathered}
$$

Taigi išëjimo signalą $y(t)$ galima užrašyti taip:

$$
y(t)=\frac{1}{\alpha}\left(1-e^{-\alpha t}\right) u(t) .
$$

(b) Remiantis (2.10) lygtimi,

$$
y(t)=h(t) * x(t)=\int_{-\infty}^{\infty} h(\tau) x(t-\tau) d \tau .
$$



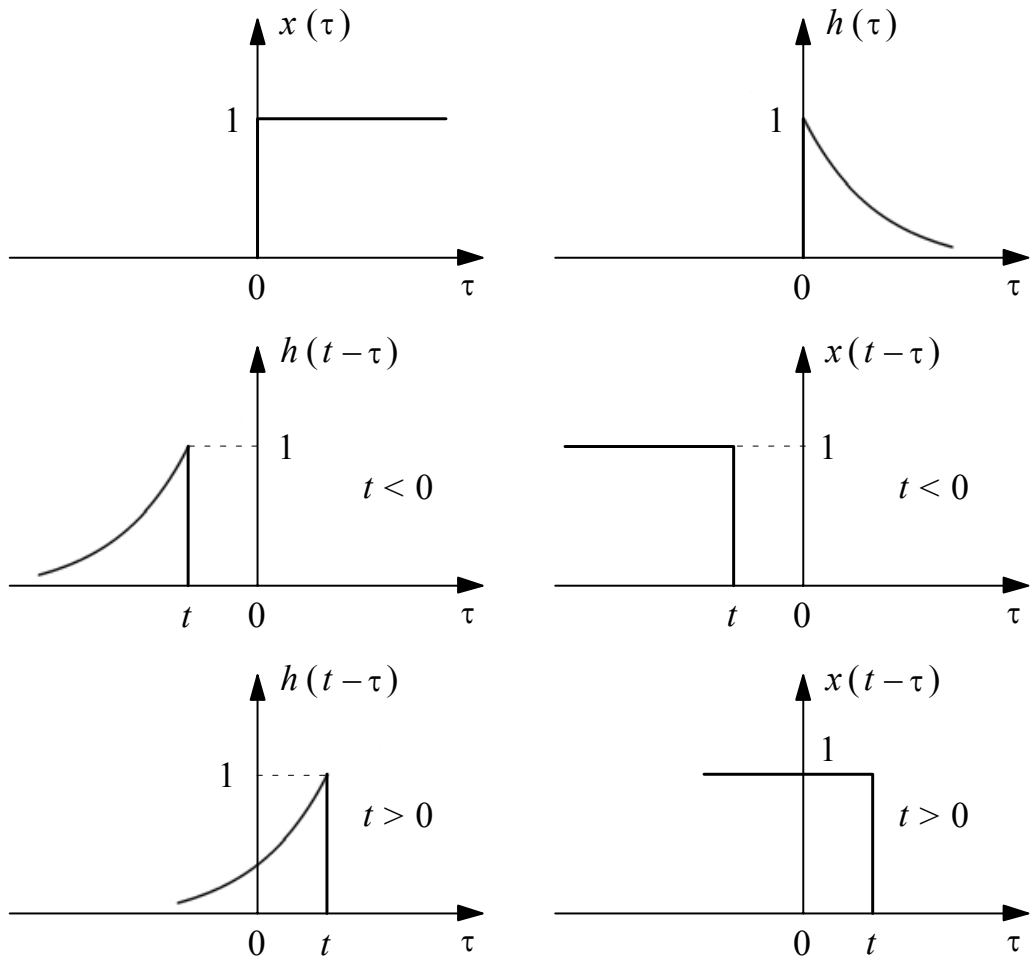

a)

b)

\section{3 pav.}

Funkcijos $h(\tau)$ ir $x(t-\tau)$ pavaizduotos 2.3 b pav., kai $t<0$ ir $t>0$. Kaip matyti iš šio paveikslo, kai $t<0, h(\tau)$ ir $x(t-\tau)$ nepersidengia. O kai $t>0$, funkcijos persidengia intervale nuo $\tau=0$ iki $\tau=t$. Todèl, kai $t<0, y(t)=0$. Kai $t>0$, sistemos atsakas lygus:

$$
y(t)=\int_{0}^{t} e^{-\alpha \tau} d \tau=\frac{1}{\alpha}\left(1-e^{-\alpha t}\right) .
$$


Taigi išejimo signalą $y(t)$ galima užrašyti taip:

$$
y(t)=\frac{1}{\alpha}\left(1-e^{-\alpha t}\right) u(t) .
$$

Kaip matome, ši lygtis identiška (2.30) lygčiai.

2.2. Duota tolydinè tiesinè stacionarioji sistema, kurios atsakas į vienetinị šuoli aprašomas taip:

$$
s(t)=e^{-t} u(t) .
$$

Raskite šios sistemos atsaką i 2.4 pav. pavaizduotą ièjimo signalą $x(t)$.

\section{Sprendimas}

Kaip matyti iš 2.4 pav., iejjimo signalą $x(t)$ galima išreikšti taip:

$$
x(t)=u(t-1)-u(t-3) .
$$

Kadangi sistema yra tiesinè ir stacionarioji, jos išèjimo signalą galima užrašyti taip:

$$
\begin{gathered}
y(t)=s(t-1)-s(t-3) \\
=e^{-(t-1)} u(t-1)-e^{-(t-3)} u(t-3) .
\end{gathered}
$$

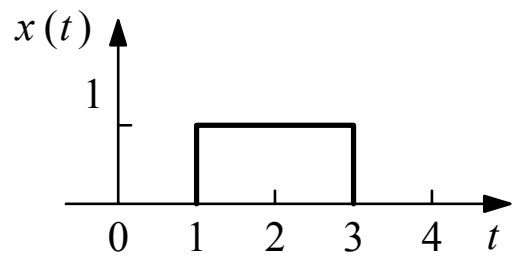

2.4 pav. 
2.3. Duota tolydinè tiesinè stacionarioji sistema, kurios iejjimo ir išëjimo signalai susiję taip:

$$
y(t)=\int_{-\infty}^{t} e^{-(t-\tau)} x(\tau) d \tau .
$$

(a) Raskite šios sistemos impulsinę charakteristiką $h(t)$.

(b) Irodykite, kad kompleksinè eksponente $e^{s t}$ yra tikrinè sistemos funkcija.

(c) Raskite sistemos tikrinę vertę, atitinkančią $e^{s t}$, naudodami prieš tai rastą impulsinę charakteristiką $h(t)$.

\section{Sprendimas}

(a) Remiantis (2.32) lygtimi ir (2.1) apibrèžimu,

$$
h(t)=\int_{-\infty}^{t} e^{-(t-\tau)} \delta(\tau) d \tau=\left.e^{-(t-\tau)}\right|_{\tau=0}=e^{-t} \quad t>0 .
$$

Taigi

$$
h(t)=e^{-t} u(t) .
$$

(b) Tarkime, $\operatorname{kad} x(t)=e^{s t}$. Tuomet

$$
\begin{gathered}
y(t)=\int_{-\infty}^{t} e^{-(t-\tau)} e^{s \tau} d \tau=e^{-t} \int_{-\infty}^{t} e^{(s+1) \tau} d \tau \\
=\frac{1}{s+1} e^{s t}=\lambda e^{s t}, \quad \text { jei } \operatorname{Re} s>-1 .
\end{gathered}
$$

Taigi, remiantis (2.22) apibrēžimu, $e^{s t}$ yra sistemos tikrinè funkcija, kurios tikrinè vertè

$$
\lambda=\frac{1}{s+1} .
$$


(c) Remiantis (2.24) ir (2.33) lygtimis, su $e^{s t}$ susijusi tikrinè verte aprašoma taip:

$$
\begin{aligned}
\lambda & =H(s)=\int_{-\infty}^{\infty} h(\tau) e^{-s \tau} d \tau=\int_{-\infty}^{\infty} e^{-\tau} u(\tau) e^{-s \tau} d \tau \\
& =\int_{0}^{\infty} e^{-(s+1) \tau} d \tau=\frac{1}{s+1}, \quad \text { jei } \operatorname{Re} s>-1 .
\end{aligned}
$$

Gautas rezultatas atitinka (2.35) lygti.

2.4. Tolydinę sistemą, pavaizduotą 2.5 pav., sudaro integratorius ir skaliarinis daugintuvas. Užrašykite diferencialinę lygti, susiejančią išèjimo signalą $y(t)$ su ieejimo signalu $x(t)$.

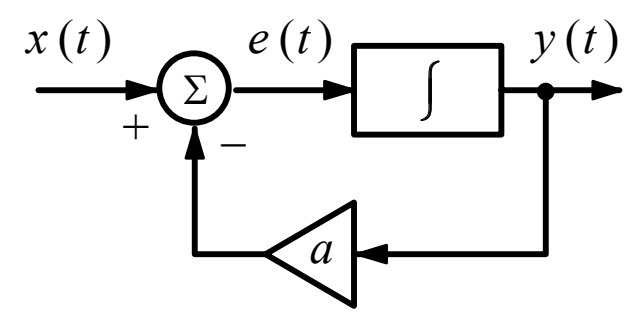

2.5 pav.

\section{Sprendimas}

Tarkime, kad $e(t)-2.5$ pav. pavaizduoto integratoriaus iejjimo signalas. Tuomet sąryšis tarp integratorius iejjimo ir išèjimo signalu užrašomas taip:

$$
y(t)=\int_{-\infty}^{t} e(\tau) d \tau .
$$


Diferencijuojant abi (2.36) lygties puses $t$ atžvilgiu, gaunama

$$
\frac{d y(t)}{d t}=e(t)
$$

Remiantis 2.5 pav., integratoriaus įejjimo signalą galima užrašyti taip:

$$
e(t)=x(t)-a y(t)
$$

Istačius (2.38) lygti i (2.37), gaunama:

$$
\frac{d y(t)}{d t}=x(t)-a y(t) .
$$

Pastarąją lygybę galima perrašyti taip:

$$
\frac{d y(t)}{d t}+x(t)=a y(t)
$$

Gautoji išraiška ir yra pirmosios eilès tiesinè diferencialinè lygtis, kurią reikejjo išvesti.

2.5. Duota tolydinè sistema, kurios įejjimo signalas $x(t)$ ir išèjimo signalas $y(t)$ susiję taip:

$$
\frac{d y(t)}{d t}+a y(t)=x(t)
$$

čia $a$ - konstanta.

(a) Raskite $y(t)$, naudodami pagalbinę sąlygą $y(0)=y_{0}$ ir

$$
x(t)=K e^{-b t} u(t) .
$$

(b) Išreikškite $y(t)$ sistemos reakcijų, esant nuliniam ièjimo signalui ir nulinėms pagalbinèms sąlygoms, suma. 


\section{Sprendimas}

(a) Tarkime, kad

$$
y(t)=y_{d}(t)+y_{b}(t)
$$

čia $y_{d}(t)$ - dalinis sprendinys, tenkinantis (2.40) lygti, o $y_{b}(t)-$ bendrasis sprendinys, tenkinantis:

$$
\frac{d y_{b}(t)}{d t}+a y_{b}(t)=0
$$

Darome prielaidą, kad:

$$
y_{d}(t)=A e^{-b t}, \quad t>0 .
$$

Istatę (2.43) lygti i (2.40), gauname:

$$
-b A e^{-b t}+a A e^{-b t}=K e^{-b t},
$$

Iš pastarosios išraiškos matyti, kad $A=K /(a-b), \mathrm{o}$

$$
y_{d}(t)=\frac{K}{a-b} e^{-b t}, \quad t>0 .
$$

Norėdami rasti $y_{b}(t)$, darome prielaida, kad:

$$
y_{b}(t)=B e^{s t} .
$$

Istačius šią lygtị i (2.42), gaunama:

$$
s B e^{s t}+a B e^{s t}=(s+a) B e^{s t}=0 .
$$

Iš šios lygybès išeina, $\operatorname{kad} s=-a, \mathrm{o}$

$$
y_{b}(t)=B e^{-a t}
$$

Sujungus i vieną $y_{d}(t)$ ir $y_{b}(t)$ išraiškas, gaunama:

$$
y(t)=B e^{-a t}+\frac{K}{a-b} e^{-b t}, t>0 .
$$


Remiantis (2.45) lygtimi ir pagalbine salyga $y(0)=y_{0}$, galima užrašyti:

$$
B=y_{0}-\frac{K}{a-b} .
$$

Taigi (2.45) lygti galima perrašyti taip:

$$
y(t)=\left(y_{0}-\frac{K}{a-b}\right) e^{-a t}+\frac{K}{a-b} e^{-b t}, \quad t>0 .
$$

Kai $t<0, x(t)=0$, ir (2.40) lygtis virsta (2.42). Taigi

$$
y(t)=B e^{-a t}, \quad t<0 .
$$

Pasinaudojus pagalbine sąlyga $y(0)=y_{0}$, galima užrašyti:

$$
y(t)=y_{0} e^{-a t}, \quad t<0 .
$$

(b) Sujungiant (2.46) ir (2.47) lygtis, $y(t)$ galima išreikšti $y_{n s}$ (reakcija, esant nuliniam iejimo signalui) ir $y_{n p}$ (reakcija, esant nulinėms pagalbinèms sąlygoms) suma:

$$
\begin{gathered}
y(t)=y_{0} e^{-a t}+\frac{K}{a-b}\left(e^{-b t}-e^{-a t}\right) u(t) \\
=y_{n s}(t)+y_{n p}(t),
\end{gathered}
$$

čia

$$
\begin{gathered}
y_{n s}(t)=y_{0} e^{-a t}, \\
y_{n p}(t)=\frac{K}{a-b}\left(e^{-b t}-e^{-a t}\right) u(t) .
\end{gathered}
$$




\subsection{Uždaviniai}

2.6. Irodykite, kad:

(a) $x(t) * h(t)=x(t)$

(b) $\left\{x(t) * h_{1}(t)\right\} * h_{2}(t)=x(t) *\left\{h_{1}(t) * h_{2}(t)\right\}$.

2.7. Irodykite, kad:

(a) $x(t) * \delta(t)=h(t) * x(t)$;

(b) $x(t) * \delta\left(t-t_{0}\right)=x\left(t-t_{0}\right)$;

(c) $x(t) * u(t)=\int_{-\infty}^{t} x(\tau) d \tau$;

(d) $x(t) * u\left(t-t_{0}\right)=\int_{-\infty}^{-\infty} x(\tau) d \tau$.

2.8. Tarkime, kad $y(t)=x(t) * h(t)$. Irodykite, kad:

$$
x\left(t-t_{1}\right) * h\left(t-t_{2}\right)=y\left(t-t_{1}-t_{2}\right)
$$

2.9. Apskaičiuokite tolydinès tiesinès stacionariosios sistemos išèjimo signalą $y(t)$, jei sistemos impulsinè charakteristika $h(t)$ ir iejjimo signalas $x(t)$ aprašomi taip:

$$
\begin{array}{ll}
h(t)=e^{-\alpha t} u(t) \quad x(t)=e^{\alpha t} u(-t) \quad \alpha>0 \\
\text { Ats. } y(t)=\frac{1}{2 \alpha} e^{-\alpha|t|} \quad \alpha>0 .
\end{array}
$$

2.10. Apskaičiuokite $y(t)=x(t) * h(t)$, naudodami 2.6 pav. pateiktus grafikus. Skaičiavimą atlikite: (a) analitiniu metodu, (b) grafiniu metodu. 

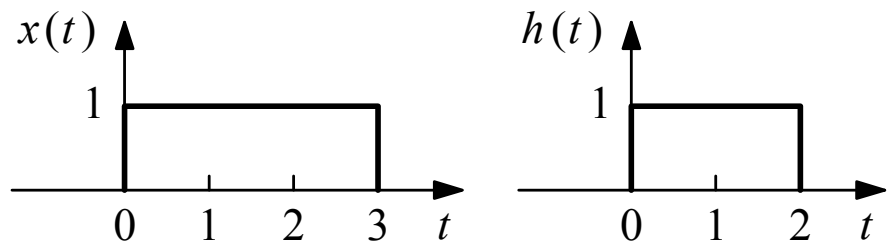

2.6 pav.

Ats. $y(t)=t u(t)-(t-2) u(t-2)-(t-3) u(t-3)+(t-5) u(t-5)$.

2.11. Jei $x_{1}(t)$ ir $x_{2}(t)$ yra periodiniai signalai, turintys tą pati periodą $T_{0}, x_{1}(t)$ ir $x_{2}(t)$ sąsūka nekonverguoja. Šiuo atveju apibrèžiama $x_{1}(t)$ ir $x_{2}(t)$ periodinè sąsūka:

$$
f(t)=x_{1}(t) \otimes x_{2}(t)=\int_{0}^{T_{0}} x_{1}(\tau) x_{2}(t-\tau) d \tau .
$$

(a) Irodykite, kad $f(t)$ - periodinè funkcija, kurios periodas lygus $T_{0}$.

(b) Irodykite, kad bet kokiam $a$ galioja:

$$
f(t)=\int_{a}^{a+T_{0}} x_{1}(\tau) x_{2}(t-\tau) d \tau .
$$

(c) Apskaičiuokite 2.7 pav. pavaizduoto signalo $x(t)$ periodinę sąsūką su savimi. 


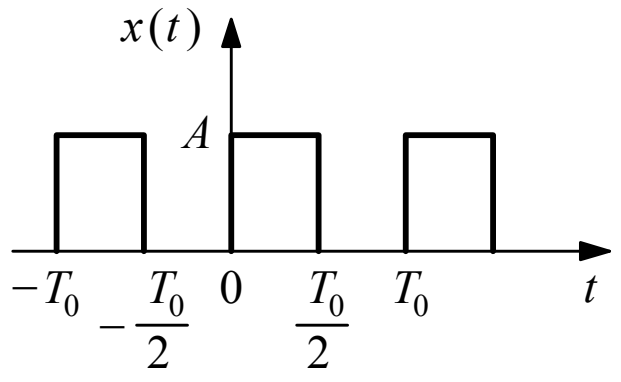

2.7 pav.

Ats. (c) $f(t)=\left\{\begin{array}{cc}A^{2} t & 0<t \leq T_{0} / 2 \\ -A^{2}\left(t-T_{0}\right) & T_{0} / 2<t \leq T_{0}\end{array}\right.$

ir $f\left(t+T_{0}\right)=f(t)$

2.12. Duota tolydinè tiesinè stacionarioji sistema, kurios iejjimo signalas $x(t)$ ir išèjimo signalas $y(t)$ pavaizduoti atitinkamai 2.8 a ir b pav. Nubraižykite šios sistemos išejjimo signalą, esant tokiems įėjimo signalams: (a) $x(t-2)$, (b) $\frac{1}{2} x(t)$.

Ats. (a) Žr. 2.9 a pav.; $\quad$ (b) Žr. 2.9 b pav.

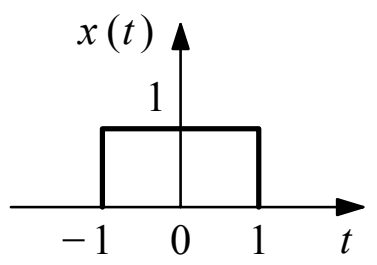

a)

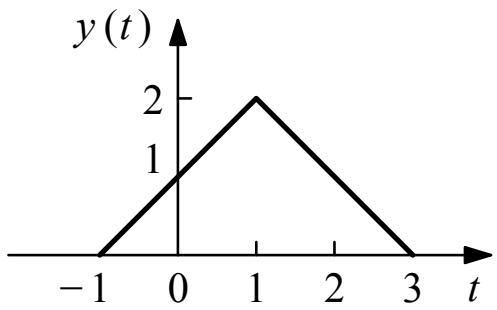

b)

2.8 pav. 


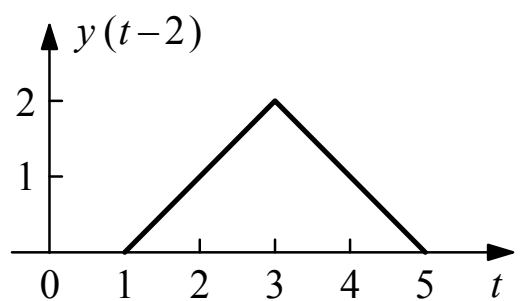

a)

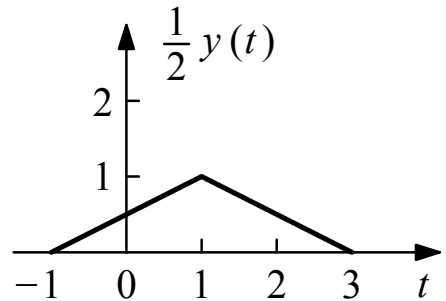

b)

\section{9 pav.}

2.13. Duota tolydinè tiesinè stacionarioji sistema, aprašoma taip:

$$
y(t)=\mathbf{T}\{x(t)\}=\frac{1}{T} \int_{t-T / 2}^{t+T / 2} x(\tau) d \tau .
$$

(a) Raskite sistemos impulsinę charakteristiką $h(t)$.

(b) Ar ši sistema - priežastinè?

Ats. (a) $h(t)=\left\{\begin{array}{cc}1 / T & -T / 2<t \leq T / 2, \\ 0 & t<-T / 2 \text { ir } t \geq T / 2\end{array}\right.$; (b) Ne.

2.14. Tarkime, kad $y(t)$ yra tolydinès tiesinès stacionariosios sistemos atsakas i iejjimo signalą $x(t)$. Raskite sistemos atsaką i ièjimo signalą $x^{\prime}(t)$, kuris yra pirmoji $x(t)$ išvestinè.

$$
\text { Ats. } y^{\prime}(t)=h(t) * x^{\prime}(t) \text {. }
$$

2.15. Sistema, pavaizduota 2.10 a pav., yra pakopinis dvieju sistemų junginys. Šių sistemų impulsinès charakteristikos yra atitinkamai $h_{1}(t)$ ir $h_{2}(t)$ : 


$$
h_{1}(t)=e^{-2 t} u(t) \text { ir } h_{2}(t)=2 e^{-t} u(t)
$$

(a) Raskite visos sistemos, pavaizduotos 2.10 b pav., impulsinę charakteristiką $h(t)$.

(b) Nustatykite, ar tokia sistema stabilioji.

Ats. (a) $h(t)=2\left(e^{-t}-e^{-2 t}\right) u(t)$; (b) Taip.

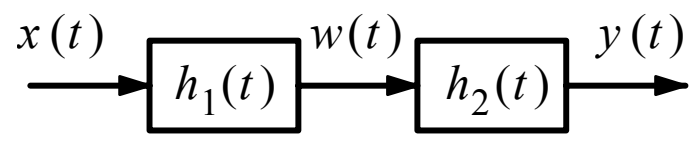

a)

b)

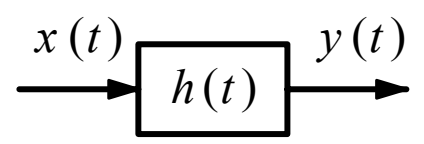

\subsection{0 pav.}

2.16. Duota tolydinė tiesinè stacionarioji sistema, aprašoma taip:

$$
y(t)=\frac{1}{T} \int_{t-T / 2}^{t+T / 2} x(\tau) d \tau .
$$

(a) Raskite sistemos tikrinę vertę, atitinkančią tikrinę funkciją $e^{s t}$

(b) Pakartokite skaičiavimą, naudodami sistemos impulsinę charakteristiką $h(t)$. 
Ats. $\lambda=\frac{1}{s T}\left(e^{s T / 2}-e^{-s T / 2}\right)$.

2.17. Duota stabilioji tolydinè tiesine stacionarioji sistema, kurios impulsinè charakteristika $h(t)$ yra realioji ir lyginè. Irodykite, $\mathrm{kad} \cos \omega t$ ir $\sin \omega t$ yra šios sistemos tikrinės funkcijos, turinčios tą pačią realiąją tikrinę vertę.

2.18. Tolydinę sistemą, pavaizduotą 2.11 pav., sudaro du integratoriai ir du skaliariniai daugintuvai. Užrašykite diferencialinę lygti, susiejančią išèjimo signalą $y(t)$ su iejjimo signalu $x(t)$.

$$
\text { Ats. } \frac{d^{2} y(t)}{d t^{2}}+a_{1} \frac{d y(t)}{d t}+a_{2} y(t)=x(t) .
$$

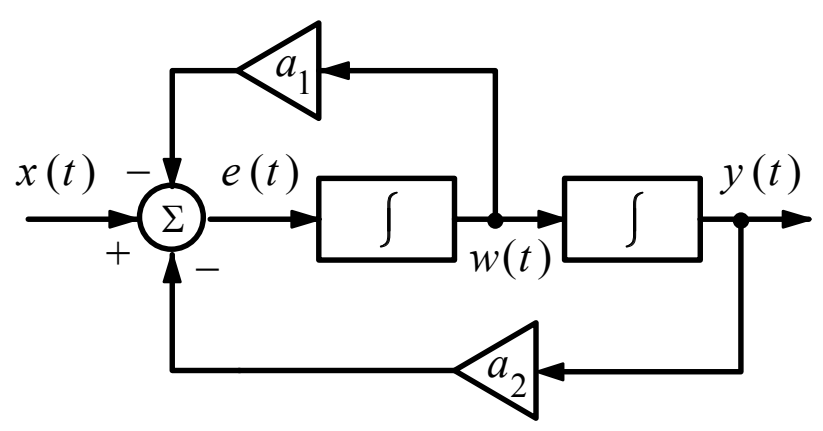

2.11 pav.

2.19. Žr. sistemą, aprašytą 2.5 uždavinyje.

(a) Irodykite, kad sistema nèra tiesinè, jei $y(0)=y_{0} \neq 0$.

(b) Irodykite, kad sistema yra tiesinè, jei $y(0)=0$.

2.20. Žr. sistemą, aprašytą 2.5 uždavinyje. Irodykite, kad pradiné pusiausvyros būsena $y(0)=0$ taip pat reiškia, jog sistema yra stacionarioji. 
2.21 Žr. sistemą, aprašytą 2.5 uždavinyje. Raskite sistemos impulsinę charakteristiką $h(t)$.

$$
\text { Ats. } h(t)=e^{-a t} u(t) .
$$

2.22. Žr. sistemą, aprašytą 2.5 uždavinyje. Jei $y(0)=0$,

(a) raskite sistemos šuolini atsaką $s(t)$, nenaudodami impulsinès charakteristikos $h(t)$;

(b) raskite sistemos šuolini atsaką $s(t)$, naudodami 2.21 uždavinyje rastą impulsinę charakteristiką $h(t)$;

(c) raskite impulsinę charakteristiką $h(t)$ iš $s(t)$.

$$
\text { Ats. } s(t)=\frac{1}{a}\left(1-e^{-a t}\right) u(t) ; \quad h(t)=e^{-a t} u(t) .
$$

2.23. Duota sistema, aprašoma taip:

$$
y^{\prime}(t)+2 y(t)=x(t)+x^{\prime}(t) .
$$

Raskite sistemos impulsinę charakteristiką $h(t)$.

$$
\text { Ats. } h(t)=-e^{-2 t} u(t)+\delta(t) .
$$




\section{LAPLASO TRANSFORMACIJA IR TSS}

\subsection{Ivadas}

Vienas iš svarbiausių dalykų, aptartų antrajame skyriuje, yra tai, kad TSS atsaką i iejjimo signalą galima rasti skaičiuojant šio signalo sąsūką su sistemos impulsine charakteristika. Šiame skyriuje pateikiamas alternatyvus būdas signalams ir TSS vaizduoti. Tolydiniams signalams vaizduoti kompleksinio kintamojo $s$ plokštumoje bus pasitelkta Laplaso transformacija, o tolydiniams TSS sistemos funkcija. Taikant Laplaso transformacijos metodą, galima daug ką sužinoti apie TSS savybes. Šios žinios labai praverčia sprendžiant uždavinius, susijusius su tokiomis sistemomis.

\subsection{Laplaso transformacija}

Kaip buvo aptarta 2.4 poskyryje, tolydinès TSS, apibūdinamos impulsine charakteristika $h(t)$, atsakas $y(t)$ i̇ kompleksinès eksponentẻs pavidalo ièjimo signalą $e^{s t}$ yra toks:

$$
y(t)=\mathbf{T}\left\{e^{s t}\right\}=H(s) e^{s t},
$$

čia

$$
H(s)=\int_{-\infty}^{\infty} h(t) e^{-s t} d t .
$$




\section{Apibrèžimas}

3.2 lygtyje esanti funkcija $H(s)$ vadinama $h(t)$ (dvipuse) Laplaso transformacija. Bendruoju atveju tolydinio signalo $x(t)$ Laplaso transformacija $X(s)$ apibrěžiama taip:

$$
X(s)=\int_{-\infty}^{\infty} x(t) e^{-s t} d t .
$$

Kintamasis $s$ paprastai yra kompleksinis ir užrašomas taip:

$$
s=\sigma+j \omega .
$$

(3.3) lygtis gali būti laikoma operatoriumi, transformuojančiu signalą $x(t)$ i funkciją $X(s)$. Sakoma, kad ši funkcija ir signalas sudaro Laplaso transformacijos porą, žymimą tokiu simboliu:

$$
x(t) \leftrightarrow X(s) .
$$

\section{Konvergavimo sritis}

Kompleksinio kintamojo $s$ verčių diapazonas, kuriame konverguoja Laplaso transformacija, vadinamas konvergavimo sritimi (KS). Laplaso transformacijai ir su ja susijusiai konvergavimo sričiai iliustruoti panagrinèkime tokị pavyzdị.

\section{1 pavyzdys}

Tarkime, kad duotas signalas

$$
x(t)=e^{-a t} u(t), \quad a-\text { realusis sk. }
$$

Remiantis (3.3) lygtimi, $x(t)$ Laplaso transformacija yra: 


$$
\begin{gathered}
X(s)=\int_{-\infty}^{\infty} e^{-a t} u(t) e^{-s t} d t=\int_{0}^{\infty} e^{-(s+a) t} d t \\
=-\left.\frac{1}{s+a} e^{-(s+a) t}\right|_{0} ^{\infty}=\frac{1}{s+a} \quad \operatorname{Re}(s)>-a,
\end{gathered}
$$

nes $\quad \lim e^{-(s+a) t}=0 \quad$ tik tuomet, kai $\operatorname{Re}(s+a)>0 \quad$ arba $\operatorname{Re}(s) \stackrel{t \rightarrow \infty}{>}-a$.

Kaip matyti iš (3.7) lygties, konvergavimo sritị nusako nelygybẻ $\operatorname{Re}(s)>-a$. Ji atitinka užbrūkšniuotą kompleksinès plokštumos plotą i dešinę nuo tiesès $\operatorname{Re}(s)=-a$ (žr. 3.1 pav.).

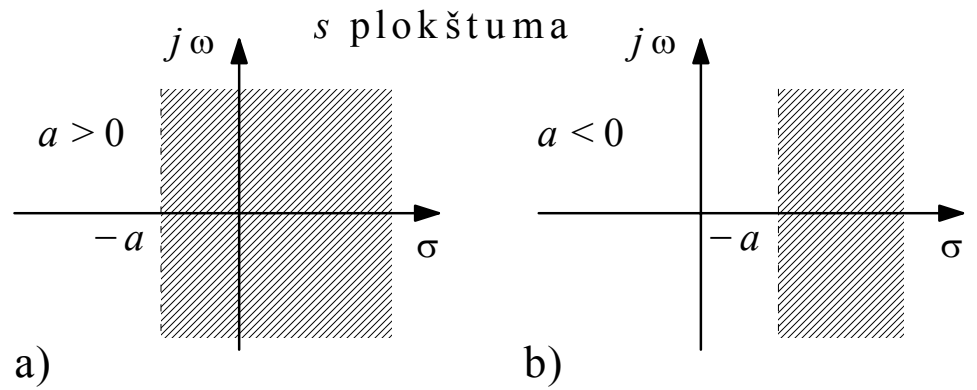

3.1 pav. Konvergavimo sritis

Uždaviniuose, kuriuose taikoma Laplaso transformacija, kompleksinè plokštuma paprastai vadinama s plokštuma.

\section{$X(s)$ poliai ir nuliai}

Paprastai $X(s)$ būna racionalioji $s$ funkcija, t. y. 


$$
X(s)=\frac{a_{0} s^{m}+a_{1} s^{m-1}+\cdots+a_{m}}{b_{0} s^{n}+b_{1} s^{n-1}+\cdots+b_{n}}=\frac{a_{0}}{b_{0}} \frac{\left(s-z_{1}\right) \cdots\left(s-z_{m}\right)}{\left(s-p_{1}\right) \cdots\left(s-p_{n}\right)}
$$

Koeficientai $a_{k}$ ir $b_{k}$ yra realiosios konstantos, $m$ ir $n$ - teigiami sveikieji skaičiai. $X(s)$ vadinama taisyklingaja racionaliąja funkcija, jei $n>m$, arba netaisyklingaja racionaliaja funkcija, jei $n \leq m$. Skaitiklio polinomo šaknys $z_{k}$ vadinamos $X(s)$ nuliais, nes šioms $s$ vertèms $X(s)=0$. O vardiklio polinomo šaknys $p_{k}$ vadinamos $X(s)$ poliais, nes šioms $s$ vertems $X(s)$ yra begalybé. Taigi $X(s)$ poliai yra už konvergavimo srities ribų, nes pagal apibrèžimą $X(s)$ poliuose nekonverguoja. Kita vertus, nuliai gali būti tiek konvergavimo srities ribose, tiek ir už jų. Jei nepaisysime daugiklio $a_{0} / b_{0}, X(s)$ galima visiškai apibūdinti jos nuliais ir poliais.

Kiekvieno poliaus padètị $s$ plokštumoje priimta žymèti „×“, o nulio - „॰“ Tai iliustruoja 3.2 pav., kuriame pavaizduota tokia $X(s)$ :

$$
X(s)=\frac{2 s+4}{s^{2}+4 s+3}=2 \frac{s+2}{(s+1)(s+3)} \quad \operatorname{Re}(s)>-1 .
$$

Kaip matome, $X(s)$ turi vieną nuli taške $s=-2$ ir du polius taškuose $s=-1$ ir $s=-3$, esant daugikliui 2 .

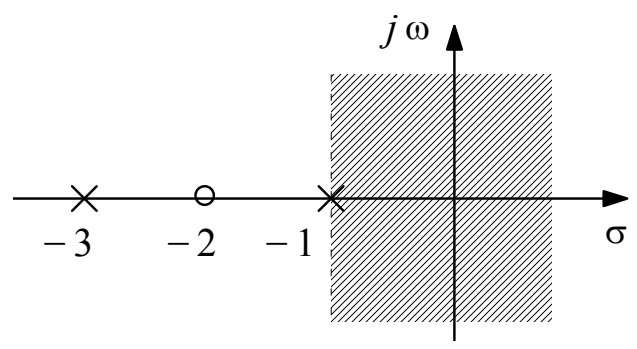

3.2 pav. $X(s)=(2 s+4) /\left(s^{2}+4 s+3\right)$ vaizdavimas $s$ plokštumoje 


\section{Konvergavimo srities savybės}

Kaip matyti iš 3.1 pavyzdžio, $X(s)$ konvergavimo sritis priklauso nuo $x(t)$ pobūdžio. Jei $X(s)$ yra racionalioji $s$ funkcija, jai būdingos penkios toliau aprašytos savybès.

1. Konvergavimo srityje nebūna polių.

2. Jei $x(t)$ yra baigtinès trukmés signalas, t. y. $x(t)=0$ visur, išskyrus baigtini intervalą $t_{1} \leq t \leq t_{2}\left(-\infty<t_{1}, t_{2}<\infty\right)$, tai konvergavimo sritis apima visą $s$ plokštumą, išskyrus galbūt $s=0$ arba $s=\infty$.

3. Jei $x(t)$ yra dešiniapusis signalas, t. y. $x(t)=0$, kai $t<t_{1}<\infty$, tai konvergavimo sritis yra:

$$
\operatorname{Re}(s)>\sigma_{\text {max }},
$$

čia $\sigma_{\max }$ lygus bet kurio iš $X(s)$ poliu didžiausiai realiajai daliai. Taigi konvergavimo sritis apima pusplokštumę i dešinę nuo vertikalios tiesès $\operatorname{Re}(s)=\sigma_{\max } s$ plokštumoje (ir kartu į dešinę nuo visų $X(s)$ poliu).

4. Jei $x(t)$ yra kairiapusis signalas, t. y. $x(t)=0$, kai $t>t_{2}>-\infty$, tai konvergavimo sritis yra:

$$
\operatorname{Re}(s)<\sigma_{\text {min }},
$$

čia $\sigma_{\min }$ lygus bet kurio iš $X(s)$ poliu mažiausiai realiajai daliai. Taigi konvergavimo sritis apima pusplokštumę i kairę nuo vertikalios tiesès $\operatorname{Re}(s)=\sigma_{\max } s$ plokštumoje (ir kartu ị kairę nuo visu $X(s)$ poliu $)$.

5. Jei $x(t)$ yra dvipusis signalas, t. y. neribotos trukmès signalas, kuris nèra nei dešiniapusis, nei kairiapusis, tai konvergavimo sritis yra:

$$
\sigma_{1}<\operatorname{Re}(s)<\sigma_{2},
$$

čia $\sigma_{1}$ ir $\sigma_{2}-$ dviejų $X(s)$ polių realiosios dalys. Šiuo atveju konvergavimo sritis yra vertikali juosta $s$ plokštumoje, esanti tarp vertikalių $\operatorname{Re}(s)=\sigma_{1}$ ir $\operatorname{Re}(s)=\sigma_{2}$. 


\subsection{Dažnai sutinkamų signalų Laplaso transformacijos}

\section{Vienetinio impulso funkcija $\delta(t)$}

Pasinaudojus (3.3) lygtimi, galima užrašyti:

$$
\int_{-\infty}^{\infty} \delta(t) e^{-s t} d t=1 \quad \text { visoms } s
$$

Vienetinio šuolio funkcija $u(t)$

$$
\int_{-\infty}^{\infty} u(t) e^{-s t} d t=\int_{0}^{\infty} e^{-s t} d t=-\left.\frac{1}{s} e^{-s t}\right|_{0} ^{\infty}=\frac{1}{s} \quad \operatorname{Re}(s)>0
$$

Kitų signalų Laplaso transformacijų poros

Kai kurių dažnai sutinkamų signalų Laplaso transformacijos pateiktos 3.1 lentelèje. Naudojant šią lentelę, nebūtina kiekvieną kartą skaičiuoti Laplaso transformacijos integralo. 
3.1 lentelè. Laplaso transformacijos poros

\begin{tabular}{|c|c|c|}
\hline$x(t)$ & $X(s)$ & Konvergavimo sritis \\
\hline$\delta(t)$ & 1 & visa $s$ plokštuma \\
\hline$u(t)$ & $\frac{1}{s}$ & $\operatorname{Re}(s)>0$ \\
\hline$-u(-t)$ & $\frac{1}{s}$ & $\operatorname{Re}(s)<0$ \\
\hline$t u(t)$ & $\frac{1}{s^{2}}$ & $\operatorname{Re}(s)>0$ \\
\hline$e^{-a t} u(t)$ & $\frac{1}{s+a}$ & $\operatorname{Re}(s)>-\operatorname{Re}(a)$ \\
\hline$-e^{-a t} u(-t)$ & $\frac{1}{s+a}$ & $\operatorname{Re}(s)<-\operatorname{Re}(a)$ \\
\hline$t e^{-a t} u(t)$ & $\frac{1}{(s+a)^{2}}$ & $\operatorname{Re}(s)>-\operatorname{Re}(a)$ \\
\hline$-t e^{-a t} u(-t)$ & $\frac{1}{(s+a)^{2}}$ & $\operatorname{Re}(s)<-\operatorname{Re}(a)$ \\
\hline $\cos \omega_{0} t u(t)$ & $\frac{s}{s^{2}+\omega_{0}^{2}}$ & $\operatorname{Re}(s)>0$ \\
\hline $\sin \omega_{0} t u(t)$ & $\frac{\omega_{0}}{s^{2}+\omega_{0}^{2}}$ & $\operatorname{Re}(s)>0$ \\
\hline$e^{-a t} \cos \omega_{0} t u(t)$ & $\frac{s+a}{(s+a)^{2}+\omega_{0}^{2}}$ & $\operatorname{Re}(s)>-\operatorname{Re}(a)$ \\
\hline$e^{-a t} \sin \omega_{0} t u(t)$ & $\frac{\omega_{0}}{(s+a)^{2}+\omega_{0}^{2}}$ & $\operatorname{Re}(s)>-\operatorname{Re}(a)$ \\
\hline
\end{tabular}




\subsection{Laplaso transformacijos savybès}

\section{Tiesiškumas}

Jei

$$
\begin{aligned}
& x_{1}(t) \leftrightarrow X_{1}(s) \quad \mathrm{KS}=R_{1}, \\
& x_{2}(t) \leftrightarrow X_{2}(s) \quad \mathrm{KS}=R_{2},
\end{aligned}
$$

tai

$$
a_{1} x_{1}(t)+a_{2} x_{2}(t) \leftrightarrow a_{1} X_{1}(s)+a_{2} X_{2}(s) \quad R^{\prime} \supset R_{1} \cap R_{2} .(3.11)
$$

Aibių teorijoje naudojamas žymėjimas $A \supset B$ reiškia, kad aibè $A$ turi savyje aibę $B$. O $A \cap B$ žymi aibiu $A$ ir $B$ sankirta. Taigi (3.11) lygybė rodo, kad gautosios Laplaso transformacijos konvergavimo sritis yra bent jau to paties dydžio, kaip toji, kuri priklauso tiek $R_{1}$, tiek $R_{2}$.

\section{Postūmis tam tikru laiku}

Jei

$$
x(t) \leftrightarrow X(s) \quad \mathrm{KS}=R,
$$

tai

$$
x\left(t-t_{0}\right) \leftrightarrow e^{-s t_{0}} X(s) \quad R^{\prime}=R .
$$

(3.12) lygtis rodo, kad postūmio tam tikru laiku operacija konvergavimo srities nekeičia. 


\section{Kitos Laplaso transformacijos savybės}

Kitos Laplaso transformacijos savybės aprašytos 3.2 lentelëje kartu su prieš tai aptartomis teisiškumo ir postūmio tam tikru laiku savybèmis.

3.2 lentelè. Laplaso transformacijos savybès

\begin{tabular}{|c|c|c|c|}
\hline Savybè & Signalas & Transformacija & Konv. sritis \\
\hline & $x(t)$ & $X(s)$ & $R$ \\
\hline & $x_{1}(t)$ & $X_{1}(s)$ & $R_{1}$ \\
\hline & $x_{2}(t)$ & $X_{2}(s)$ & $R_{2}$ \\
\hline \multirow{2}{*}{ Tiesiškumas } & $a_{1} x_{1}(t)$ & $a_{1} X_{1}(s)$ & \multirow{2}{*}{$R^{\prime} \supset R_{1} \cap R_{2}$} \\
\hline & $+a_{2} x_{2}(t)$ & $+a_{2} X_{2}(s)$ & \\
\hline $\begin{array}{l}\text { Postūmis tam } \\
\text { tikru laiku }\end{array}$ & $x\left(t-t_{0}\right)$ & $e^{-\$} 0 X(s)$ & $R^{\prime}=R$ \\
\hline $\begin{array}{l}\text { Postūmis } s \\
\text { plokštumoje }\end{array}$ & $e^{s_{0} t} x(t)$ & $X\left(s-s_{0}\right)$ & $R^{\prime}=R+\operatorname{Re}\left(s_{0}\right)$ \\
\hline $\begin{array}{l}\text { Laiko ašies } \\
\text { mastelio kei- } \\
\text { timas }\end{array}$ & $x(a t)$ & $\frac{1}{|a|} X(s)$ & $R^{\prime}=a R$ \\
\hline $\begin{array}{l}\text { Laiko ašies } \\
\text { apvertimas }\end{array}$ & $x(-t)$ & $X(-s)$ & $R^{\prime}=-R$ \\
\hline $\begin{array}{l}\text { Diferencijavi- } \\
\text { mas } t \text { atžvilgiu }\end{array}$ & $\frac{d x(t)}{d t}$ & $s X(s)$ & $R^{\prime} \supset R$ \\
\hline $\begin{array}{l}\text { Diferencijavi- } \\
\text { mas } s \text { atžvilgiu }\end{array}$ & $-t x(t)$ & $\frac{d X(s)}{d s}$ & $R^{\prime}=R$ \\
\hline Integravimas & $\int_{-\infty} x(\tau) d \tau$ & $\frac{1}{s} X(s)$ & $R^{\prime} \supset R \cap\{\operatorname{Re}(s)>0\}$ \\
\hline Sąūka & $x_{1}(t) * x_{2}(t)$ & $X_{1}(s) X_{2}(s)$ & $R^{\prime} \supset R_{1} \cap R_{2}$ \\
\hline
\end{tabular}




\subsection{Atvirkštinė Laplaso transformacija}

Norint rasti signalą $x(t)$ iš jo Laplaso transformacijos $X(s)$, praverčia atvirkštinė Laplaso transformacija.

\section{Apvertimo formulè}

Egzistuoja tam tikra procedūra, tinkanti visoms transformuotu funkcijų klasėms, pagal kurią skaičiuojamas toks linijinis integralas kompleksineje $s$ plokštumoje:

$$
x(t)=\frac{1}{2 \pi j} \int_{c-j \infty}^{c+j \infty} X(s) e^{s t} d s .
$$

Šioje formulëje realusis skaičius $c$ turi būti parinktas toks, kad, esant $X(s)$ konvergavimo sričiai $\sigma_{1}<\operatorname{Re}(s)<\sigma_{2}, c$ pakliūtų $\mathfrak{i}$ intervalą $\sigma_{1}<c<\sigma_{2}$.

\section{Lentelių su Laplaso transformacijų poromis naudojimas}

Taikant kitą $X(s)$ apvertimo metodą, ši mėginama išreikšti tokia suma:

$$
X(s)=X_{1}(s)+\cdots X_{n}(s),
$$

čia $X_{1}(s), \ldots, X_{n}(s)$ - funkcijos, kurioms žinomos atvirkštinès transformacijos $x_{1}(t), \ldots, x_{n}(t)$. Remiantis tiesiškumo savybe (3.11),

$$
x(t)=x_{1}(t)+\cdots x_{n}(t) .
$$




\section{Skaidos metodo taikymas}

Jei $X(s)$ - racionalioji funkcija, t. y. tokia, kurios išraiška yra:

$$
X(s)=\frac{N(s)}{D(s)}=k \frac{\left(s-z_{1}\right) \cdots\left(s-z_{m}\right)}{\left(s-p_{1}\right) \cdots\left(s-p_{n}\right)},
$$

tai jai apversti galima taikyti paprastą, skaidos teorema pagrisstą metoda.

(a) Kai $X(s)$ yra taisyklinga racionalioji funkcija $(m \geq n)$, galima išskirti du atvejus.

1. Jei visi $X(s)$ poliai (kitaip tariant, visi $D(s)$ nuliai) yra paprastieji (t. y. skirtingi), tai $X(s)$ galima užrašyti taip:

$$
X(s)=\frac{c_{1}}{s-p_{1}}+\cdots+\frac{c_{n}}{s-p_{n}},
$$

čia koeficientai $c_{k}$ skaičiuojami pagal formulę:

$$
c_{k}=\left.\left(s-p_{k}\right) X(s)\right|_{s=p_{k}} .
$$

2. Jei $D(s)$ turi kartotinių šaknų, t. y. jei jo sudètyje yra $\left(s-p_{i}\right)^{r}$ išraiškos daugikliu, sakoma, $\mathrm{kad} p_{i}$ yra kartotinis $X(s)$ polius, turintis kartotinumą $r$. Tuomet $X(s)$ skaidinys bus sudarytas iš tokių narių:

$$
\frac{\lambda_{1}}{s-p_{i}}+\frac{\lambda_{2}}{\left(s-p_{i}\right)^{2}} \cdots+\frac{\lambda_{r}}{\left(s-p_{i}\right)^{r}},
$$

čia

$$
\lambda_{r-k}=\left.\frac{1}{k !} \frac{d^{k}}{d s^{k}}\left[\left(s-p_{i}\right)^{r} X(s)\right]\right|_{s=p_{i} .}
$$

(b) Kai $X(s)$ yra netaisyklinga racionalioji funkcija $(m \geq n)$, taikant dalybos su liekana metodą, $X(s)$ galima užrašyti taip: 


$$
X(s)=\frac{N(s)}{D(s)}=Q(s)+\frac{R(s)}{D(s)},
$$

čia $N(s)$ ir $D(s)$ yra atitinkamai $X(s)$ skaitiklio ir vardiklio polinomai, dalmuo $Q(s)$ yra $m-n$ laipsnio polinomas, o liekana $R(s)$ yra polinomas, kurio laipsnis griežtai mažesnis už $n$. Tuomet $X(s)$ atvirkštinę Laplaso transformaciją galima apskaičiuoti, radus $Q(s)$ ir $R(s) / D(s)$ atvirkštines Laplaso transformacijas. Kadangi $R(s) / D(s)$ yra taisyklingas, šio santykio atvirkštinę Laplaso transformaciją galima apskaičiuoti prieš tai ji išskaidžius pagal jau aptartą metodą. O $Q(s)$ atvirkštinę Laplaso transformaciją galima rasti naudojant transformacijų porą

$$
\frac{d^{k} \delta(t)}{d t^{k}} \leftrightarrow s^{k} \quad k=1,2,3, \ldots
$$

\subsection{Sistemos funkcija}

\section{Apibrèžimas}

2.2 poskyryje buvo parodyta, kad tolydinès TSS išęimo signalas $y(t)$ lygus iejjimo signalo $x(t)$ ir impulsinès charakteristikos sąsūkai, t. y.

$$
y(t)=x(t) * h(t)
$$

Pritaikius sąsūkos savybę (žr. 3.2 lentelę), gaunama:

$$
Y(s)=X(s) H(s),
$$

čia $Y(s), X(s)$ ir $H(s)$ yra atitinkamai $y(t), x(t)$ ir $h(t)$ Laplaso transformacijos. (3.24) lygti galima perrašyti taip: 


$$
H(s)=\frac{Y(s)}{X(s)} .
$$

$h(t)$ Laplaso transformacija $H(s)$ vadinama sistemos (arba perdavimo) funkcija. Ši funkcija, kaip ir impulsinè charakteristika $h(t)$, visiškai apibūdina sistemą.

\section{TSS apibūdinimas}

Dauguma tolydinių TSS savybių glaudžiai susijusios su $H(s)$ charakteristikomis $s$ plokštumoje, ypač su poliu išsidèstymu ir konvergavimo sritimi.

Esant priežastinei tolydinei TSS

$$
h(t)=0, \quad t<0 .
$$

Kadangi $h(t)$ yra dešiniapusis signalas, $H(s)$ konvergavimo sritis turi tenkinti sąlygą

$$
\operatorname{Re}(s)>\sigma_{\text {max }},
$$

t. y. konvergavimo sritis apima $s$ plokštumos dalị, esančią dešiniau visu sistemos polių.

Kaip aptarta 2.3 poskyryje, tolydinè TSS būna stabilioji tada ir tik tada, kai

$$
\int_{-\infty}^{\infty}|h(t)| d t<\infty .
$$

Norint tenkinti ši reikalavimą, $H(s)$ konvergavimo sritis turi apimti $j \omega$ aši (t. y. $s=j \omega$ ).

Taigi norint, kad sistema būtų priežastinè ir stabilioji, visi $H(s)$ poliai turi būti išsidèstę kairiojoje $s$ pusplokštumèje, t. y. visų poliu realiosios dalys turi būti neigiamos. 


\section{Tiesinėmis diferencialinėmis lygtimis aprašomų TSS sistemos funkcija}

2.5 poskyryje nagrinèjome TSS, kuriu ièjimo signalas $x(t)$ ir išèjimo signalas $y(t)$ tenkina bendrąją tiesinę diferencialinę lygti su pastoviaisiais koeficientais:

$$
\sum_{k=0}^{N} a_{k} \frac{d^{k} y(t)}{d t^{k}}=\sum_{k=0}^{M} b_{k} \frac{d^{k} x(t)}{d t^{k}}
$$

Pritaikius Laplaso transformaciją ir pasinaudojus jos diferencijavimo savybe, gaunama:

$$
\sum_{k=0}^{N} a_{k} s^{k} Y(s)=\sum_{k=0}^{M} b_{k} s^{k} X(s) .
$$

Tai galima perrašyti taip:

Taigi

$$
Y(s) \sum_{k=0}^{N} a_{k} s^{k}=X(s) \sum_{k=0}^{M} b_{k} s^{k} .
$$

$$
H(s)=\frac{Y(s)}{X(s)}=\frac{\sum_{k=0}^{M} b_{k} s^{k}}{\sum_{k=0}^{N} a_{k} s^{k}} .
$$

Kaip matome, $H(s)$ visuomet būna racionalioji. Pažymètina, kad (3.28) lygtis nenurodo $H(s)$ konvergavimo srities. Ši randama atsižvelgiant i papildomus reikalavimus sistemai, pvz., priežastingumą ar stabilumą. 


\section{Sistemų sujungimas}

Kai dvi TSS sujungiamos i pakopą (3.3 a pav.), bendroji impulsinè charakteristika $h(t)$ ieškoma taip:

$$
h(t)=h_{1}(t) * h_{2}(t) .
$$

O pakopos bendrajai sistemos funkcijai rasti pakanka paprastos daugybos operacijos:

$$
H(s)=H_{1}(s) H_{2}(s) .
$$

Ši sąryšị iliustruoja 3.3 b pav.

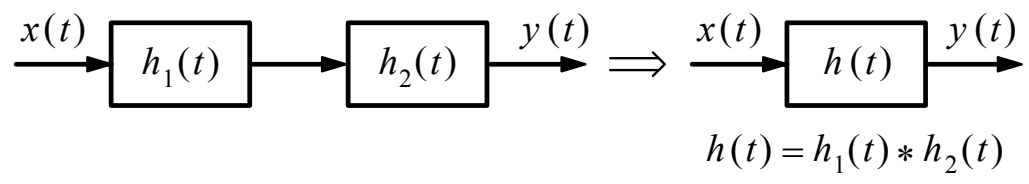

a)

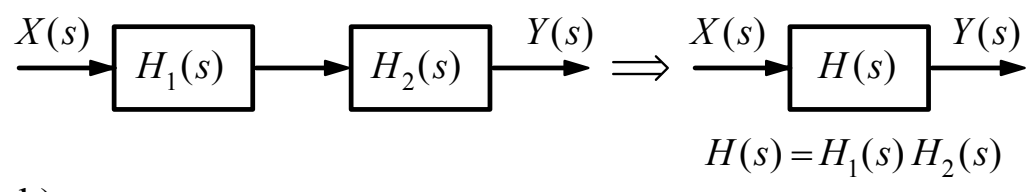

b)

3.3 pav. Pakopinis dviejų sistemų sujungimas: (a) vaizdavimas laiko atžvilgiu; (b) vaizdavimas $s$ srityje

Kai dvi TSS sujungiamos lygiagrečiai (3.4 a pav.), bendroji impulsine charakteristika $h(t)$ ieškoma taip:

$$
h(t)=h_{1}(t)+h_{2}(t) .
$$


Taigi

$$
H(s)=H_{1}(s)+H_{2}(s) .
$$

Ši sąryšị iliustruoja 3.4 b pav.

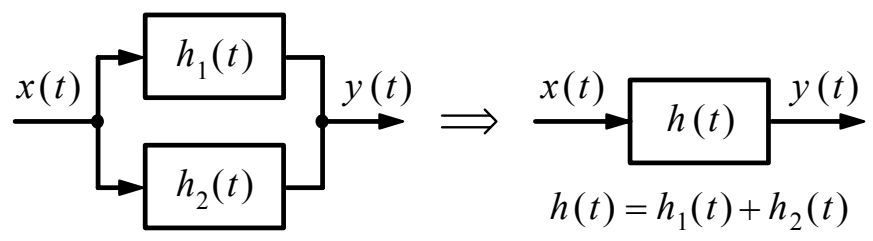

a)

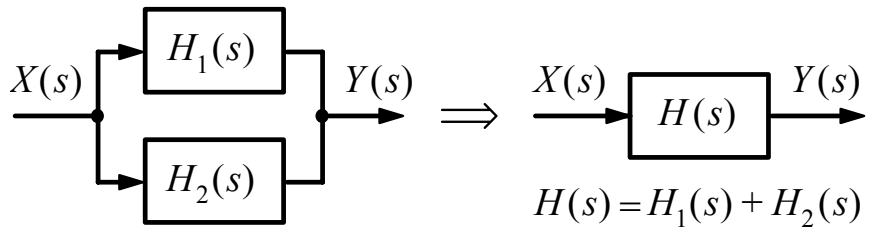

b)

3.4 pav. Lygiagretusis dviejų sistemų sujungimas: (a) vaizdavimas laiko atžvilgiu; (b) vaizdavimas $s$ srityje

\subsection{Vienpusė Laplaso transformacija}

\section{Apibrèžimas}

Vienpuse signalo $x(t)$ Laplaso transformacija $X_{I}(s)$ apibrèžiama taip:

$$
X_{I}(s)=\int_{0}^{\infty} x(t) e^{-s t} d t .
$$


Taigi vienpuse Laplaso transformacija nepaiso $x(t)$, kai $t<0$. Kadangi pagal (3.31) lygti $x(t)$ yra dešiniapusis signalas, $X_{I}(s)$ konvergavimo sritis visuomet tenkina sąlygą $\operatorname{Re}(s)>\sigma_{\max }$.

\section{Savybès}

Dauguma vienpusės Laplaso transformacijos savybių yra tokios pačios, kaip ankstesniuose poskyriuose aptartos dvipusès Laplaso transformacijos. Vienpusė Laplaso transformacija praverčia skaičiuojant priežastinès sistemos atsaką i signalą, kuomet sistema aprašoma tiesine diferencialine lygtimi su pastoviaisiais koeficientais, esant nenulinèms pradinèms sąlygoms. Šiuo atveju galima pasinaudoti tomis savybėmis, kuriomis vienpuse Laplaso transformacija skiriasi nuo dvipusés, t. y. diferencijavimu ir integravimu laiko atžvilgiu. Trumpai aptarsime šias savybes.

Diferencijavimą laiko atžvilgiu aprašo tokia išraiška:

$$
\frac{d x(t)}{d t} \leftrightarrow s X_{I}(s)-x\left(0^{-}\right),
$$

jei tik galioja $\lim _{t \rightarrow \infty} x(t) e^{-s t}=0$. Kartojant šią savybe, gaunama:

$$
\begin{gathered}
\frac{d^{2} x(t)}{d t^{2}} \leftrightarrow s^{2} X_{I}(s)-s x\left(0^{-}\right)-x^{\prime}\left(0^{-}\right), \\
\frac{d^{n} x(t)}{d t^{n}} \leftrightarrow s^{n} X_{I}(s)-s^{n-1} x\left(0^{-}\right)-\cdots-x^{(n-1)}\left(0^{-}\right),
\end{gathered}
$$

čia

$$
x^{(r)}\left(0^{-}\right)=\left.\frac{d^{r} x(t)}{d t^{r}}\right|_{t=0^{-}} .
$$


Integravimą laiko atžvilgiu aprašo tokios išraiškos:

$$
\begin{gathered}
\int_{0^{-}}^{t} x(\tau) d \tau \leftrightarrow \frac{1}{s} X_{I}(s), \\
\int_{-\infty}^{t} x(\tau) d \tau \leftrightarrow \frac{1}{s} X_{I}(s)+\frac{1}{s} \int_{-\infty}^{0^{-}} x(\tau) d \tau .
\end{gathered}
$$

\section{Sistemos funkcija}

Esant vienpusei Laplaso transformacijai sistemos funkcija $H(s)$ apibrěžta tik tuomet, kai visos pradinès sąlygos yra nulinės.

\section{Transformuotosios grandinès}

Elektros grandine apdorojamų signalų sprendinius galima rasti ir nesudarinejjant integralinių-diferencialinių lygčių, o grandinès atliekamas operacijas ir signalus pavaizdavus jų Laplaso transformacijų atitikmenimis. Iš tokių atitikmenų sudaryta grandinè vadinama transformuotaja grandine. Norint analizuoti tokią grandinę, reikia turetti Laplaso transformacijos modelius atskiriems grandinès elementams. Šie modeliai aprašyti toliau ir pavaizduoti 3.5 pav. Jie pravers analizuojant grandines 3.6 ir 3.30-3.32 uždaviniuose.

Signalo šaltiniai modeliuojami taip:

$$
v(t) \leftrightarrow V(s) \quad i(t) \leftrightarrow I(s),
$$

čia $v(t)$ ir $i(t)$ yra atitinkamai ittampos ir srovès šaltinių signalai.

Varžinis elementas $R$ modeliuojamas taip:

$$
v(t)=R i(t) \leftrightarrow V(s)=R I(s) .
$$


Induktyvusis elementas $L$ modeliuojamas taip:

$$
v(t)=L \frac{d i(t)}{d t} \leftrightarrow V(s)=s L I(s)-\operatorname{Li}\left(0^{-}\right) .
$$

Kitas 3.5 pav. pavaizduoto induktyviojo elemento $L$ modelis gaunamas perrašius (3.38) lygtị šitaip:

$$
i(t) \leftrightarrow I(s)=\frac{1}{s L} V(s)+\frac{1}{s} i\left(0^{-}\right) .
$$

Talpinis elementas $C$ modeliuojamas taip:

$$
i(t)=C \frac{d v(t)}{d t} \leftrightarrow I(s)=s C V(s)-C v\left(0^{-}\right) .
$$

Kitas 3.5 pav. pavaizduoto talpinio elemento $C$ modelis gaunamas perrašius (3.40) lygti šitaip:

$$
v(t) \leftrightarrow V(s)=\frac{1}{s C} I(s)+\frac{1}{s} v\left(0^{-}\right) .
$$

\subsection{Uždavinių sprendimo pavyzdžiai}

3.1. Raskite šių signalų Laplaso transformacijas:
(a) $x(t)=-e^{-a t} u(-t)$;
(b) $x(t)=e^{a t} u(-t)$.

\section{Sprendimas}

(a) Remiantis (3.3) lygtimi,

$$
\begin{aligned}
& X(s)=-\int_{-\infty}^{\infty} e^{-a t} u(-t) e^{-s t} d t=-\int_{-\infty}^{0^{-}} e^{-(s+a) t} d t \\
& =\left.\frac{1}{s+a} e^{-(s+a) t}\right|_{-\infty} ^{0^{-}}=\frac{1}{s+a} \quad \operatorname{Re}(s)<-a .
\end{aligned}
$$


Taigi

$$
-e^{-a t} u(-t) \leftrightarrow \frac{1}{s+a} \quad \operatorname{Re}(s)<-a .
$$

Grandinès

elementas

Modelis

Laiko
srityje

ltampos

šaltinis

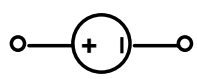

$$
v(t)
$$

Srovès

šaltinis

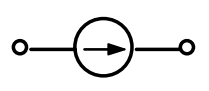

Varžinis

elementas
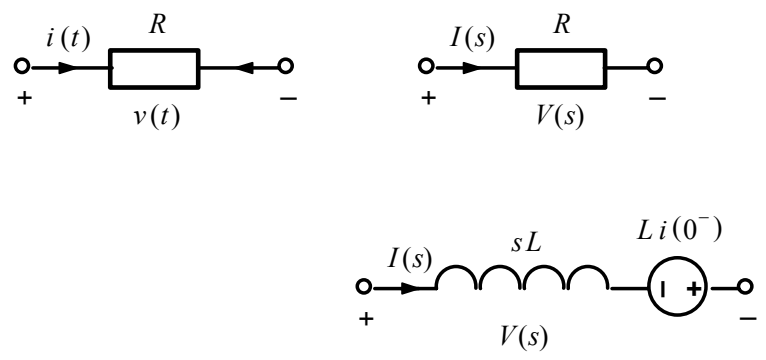

Induktyvusis elementas
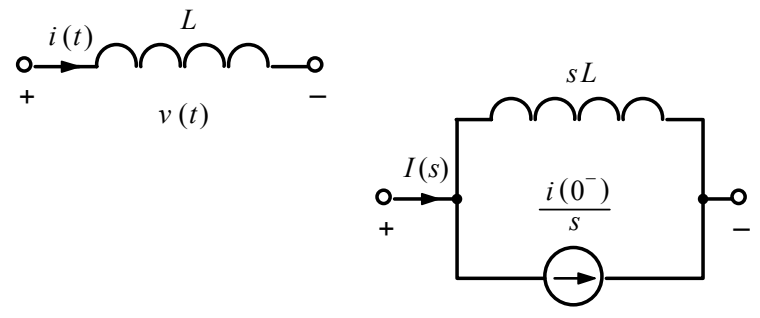

$V(s)$

3.5 pav. Transformuotosios grandinės elementų vaizdavimas 
Grandinès

elementas

Modelis

Laiko

srityje

$\stackrel{s}{\text { srityje }}$

Talpinis elementas
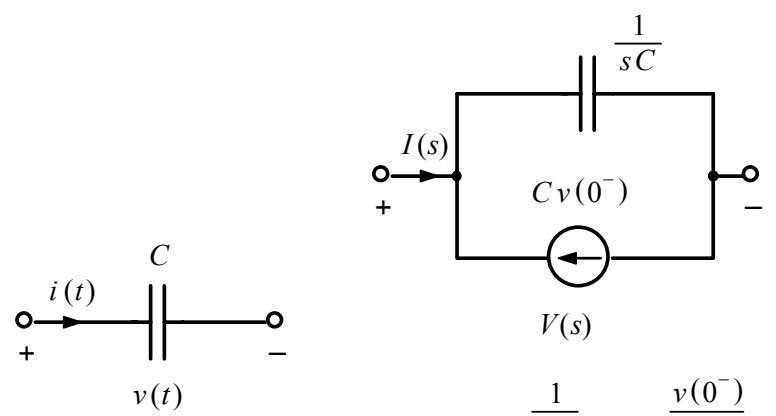

$V(s)$

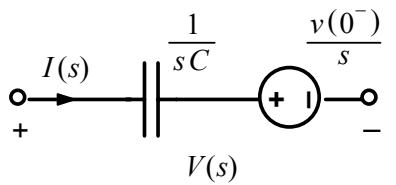

3.5 pav. (tęs.) Transformuotosios grandinès elementų vaizdavimas

(b) Remiantis (3.3) lygtimi,

$$
\begin{gathered}
X(s)=\int_{-\infty}^{\infty} e^{a t} u(-t) e^{-s t} d t=\int_{-\infty}^{0^{-}} e^{-(s-a) t} d t \\
=-\left.\frac{1}{s-a} e^{-(s-a) t}\right|_{-\infty} ^{0^{-}}=-\frac{1}{s-a} \quad \operatorname{Re}(s)<a .
\end{gathered}
$$

Taigi

$$
e^{-a t} u(-t) \leftrightarrow-\frac{1}{s-a} \quad \operatorname{Re}(s)<a
$$


3.2. Pasinaudodami Laplaso transformacijos savybèmis, iš $u(t)$ Laplaso transformacijos išveskite šiu signalų Laplaso transformacijas:
(a) $\delta(t)$
(b) $\delta^{\prime}(t)$;
(c) $\cos \omega_{0} t u(t)$.

\section{Sprendimas}

(a) Remiantis (3.10) lygtimi,

$$
u(t) \leftrightarrow \frac{1}{s}, \quad \operatorname{Re}(s)>0 .
$$

Kaip buvo aptarta 1.3 poskyryje,

$$
\delta(t)=\frac{d u(t)}{d t} .
$$

Pasinaudojus diferencijavimo laiko atžvilgiu savybe,

$$
\delta(t) \leftrightarrow s \frac{1}{s}=1 \quad \text { visoms } s .
$$

(b) Dar kartą pritaikius diferencijavimo laiko atžvilgiu savybę prieš tai gautam rezultatui,

$$
\delta^{\prime}(t) \leftrightarrow s \quad \text { visoms } s .
$$

(c) Pasinaudojus Eulerio formule, galima užrašyti:

$\cos \omega_{0} t u(t)=\frac{1}{2}\left(e^{j \omega_{0} t}+e^{-j \omega_{0} t}\right) u(t)=\frac{1}{2} e^{j \omega_{0} t} u(t)+\frac{1}{2} e^{-j \omega_{0} t} u(t)$.

Pritaikius tiesiškumo ir postūmio $s$ plokštumoje savybes,

$$
\cos \omega_{0} t u(t) \leftrightarrow \frac{1}{2} \frac{1}{s-j \omega_{0}}+\frac{1}{2} \frac{1}{s+j \omega_{0}}=\frac{s}{s^{2}+\omega_{0}^{2}} \quad \operatorname{Re}(s)>0 .
$$


3.3. Raskite tokios $X(s)$ atvirkštinę Laplaso transformaciją:

$$
X(s)=\frac{1}{s+1}, \quad \operatorname{Re}(s)>-1 .
$$

\section{Sprendimas}

Pasinaudojus 3.1 lentele,

$$
x(t)=e^{-t} u(t) .
$$

3.4. Raskite tokios $X(s)$ atvirkštinę Laplaso transformaciją:

$$
\text { (a) } X(s)=\frac{2 s+4}{s^{2}+4 s+3}, \operatorname{Re}(s)>-1 \text {. }
$$

\section{Sprendimas}

Pritaikius skaidos teoremą, galima užrašyti:

$$
X(s)=\frac{2 s+4}{s^{2}+4 s+3}=2 \frac{s+2}{(s+1)(s+3)}=\frac{c_{1}}{s+1}+\frac{c_{2}}{s+3} .
$$

Pasinaudojus (3.18) lygtimi,

$$
\begin{aligned}
& c_{1}=\left.(s+1) X(s)\right|_{s=-1}=\left.2 \frac{s+2}{s+3}\right|_{s=-1}=1, \\
& c_{2}=\left.(s+3) X(s)\right|_{s=-3}=\left.2 \frac{s+2}{s+1}\right|_{s=-3}=1 .
\end{aligned}
$$

Taigi

$$
X(s)=\frac{1}{s+1}+\frac{1}{s+3} .
$$


$X(s)$ konvergavimo sritis yra $\operatorname{Re}(s)>-1$. Todèl $x(t)$ yra dešiniapusis signalas, ir pasinaudojus 3.1 lentele,

$$
x(t)=e^{-t} u(t)+e^{-3 t} u(t)=\left(e^{-t}+e^{-3 t}\right) u(t) .
$$

Sprendimui patikrinti galima pasinaudoti MATLAB funkcija ilaplace(x), leidžiančia rasti laiko funkciją tiesiogiai iš $X(s)$. Tam galima naudoti tokią komandą:

syms $\mathrm{s} t ; \mathrm{Xs}=\left(3^{*} \mathrm{~s}+2\right) /\left(\mathrm{s}^{\wedge} 2+3^{*} \mathrm{~s}+2\right) ; \mathrm{xt}=\mathrm{ilaplace}(\mathrm{Xs}) ; \operatorname{pretty}(\mathrm{xt})$

Ivykdžius šią komandą, MATLAB komandiniame lange pasirodo toks reiškinys:

$$
\exp (-3 t)+\exp (-t)
$$

3.5. Raskite 1.13 pav. (1.3 uždavinys) pavaizduotos $R C$ grandinès sistemos funkciją $H(s)$ ir impulsinę charakteristiką $h(t)$.

\section{Sprendimas}

(a) Tarkime, kad

$$
x(t)=v_{S}(t), \quad y(t)=v_{c}(t) .
$$

Šiuo atveju $R C$ grandinè aprašoma (1.46) lygtimi:

$$
\frac{d y(t)}{d t}+\frac{1}{R C} y(t)=\frac{1}{R C} x(t) .
$$

Šiai lygčiai pritaikius Laplaso transformaciją,

$$
\left(s+\frac{1}{R C}\right) Y(s)=\frac{1}{R C} X(s) .
$$

Remiantis (3.25) lygtimi, sistemos funkcija $H(s)$ yra:

$$
H(s)=\frac{Y(s)}{X(s)}=\frac{1 / R C}{s+1 / R C}=\frac{1}{R C} \frac{1}{s+1 / R C} .
$$


Kadangi sistema yra priežastinè, $H(s)$ pritaikius atvirkštinę Laplaso transformaciją, gaunama tokia impulsinė charakteristika:

$$
h(t)=\frac{1}{R C} e^{-t / R C} u(t) .
$$

(b) Tarkime, kad

$$
x(t)=v_{S}(t), \quad y(t)=i(t) .
$$

Šiuo atveju $R C$ grandinè aprašoma (1.48) lygtimi:

$$
\frac{d y(t)}{d t}+\frac{1}{R C} y(t)=\frac{1}{R} \frac{d x(t)}{d t} .
$$

Šiai lygčiai pritaikius Laplaso transformaciją,

$$
\left(s+\frac{1}{R C}\right) Y(s)=\frac{1}{R} s X(s) .
$$

Taigi sistemos funkcija $H(s)$ yra:

$$
H(s)=\frac{Y(s)}{X(s)}=\frac{s / R}{s+1 / R C}=\frac{1}{R} \frac{s}{s+1 / R C} .
$$

Šiuo atveju sistemos funkcija yra netaisyklingoji trupmena. Todèl ją galima perrašyti taip:

$$
H(s)=\frac{1}{R} \frac{s+1 / R C-1 / R C}{s+1 / R C}=\frac{1}{R}-\frac{1}{R^{2} C} \frac{1}{s+1 / R C} .
$$

Kadangi sistema yra priežastinè, $H(s)$ pritaikius atvirkštinę Laplaso transformaciją, gaunama tokia impulsine charakteristika:

$$
h(t)=\frac{1}{R} \delta(t)-\frac{1}{R^{2} C} e^{-t / R C} u(t) .
$$

Kaip matome, skirtingos iejjimo ir išèjimo signalu poros lemia kitokią sistemos funkcijos išraišką. 
3.6. Duota $R C$ grandine, pavaizduota 3.6 pav. Jungiklis ijungiamas momentu $t=0$. Jei pradinè kondensatoriaus itampa $v_{c}\left(0^{-}\right)=v_{0}$, raskite srovę $i(t)$.

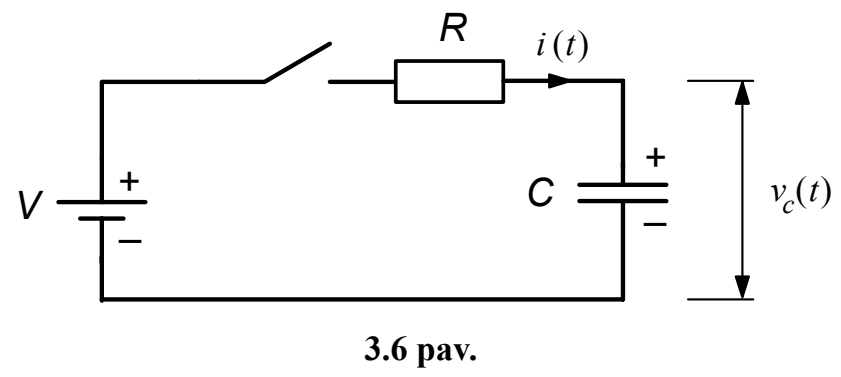

\section{Sprendimas}

Ijungus jungikli, 3.6 pav. pavaizduotą grandinę galima pakeisti

3.7 pav. pavaizduota grandine, kurioje $v_{S}(t)=V u(t)$.

Kai išèjimo signalas yra $i(t)$, o ièjimo $-v_{S}(t)$, grandinę aprašo ši diferencialinè lygtis:

$$
R i(t)+\frac{1}{C} \int_{-\infty}^{t} i(\tau) d \tau=v_{S}(t) .
$$

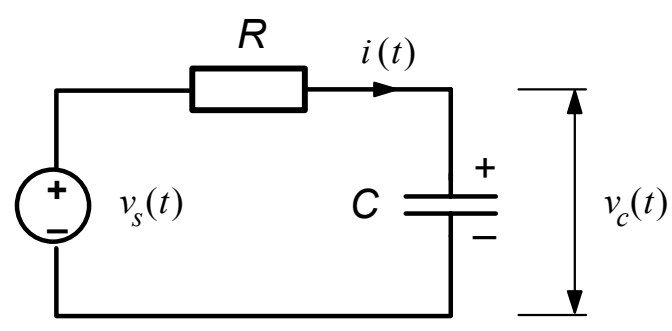

3.7 pav. 
(3.45) lygčiai pritaikius vienpusę Laplaso transformaciją ir pasinaudojus (3.36) lygtimi, gaunama:

$$
R I(s)+\frac{1}{C}\left[\frac{1}{s} I(s)+\frac{1}{S} \int_{-\infty}^{0^{-}} i(\tau) d \tau\right]=\frac{V}{s} .
$$

Kadangi

$$
v_{c}(t)=\frac{1}{C} \int_{-\infty}^{t} i(\tau) d \tau,
$$

tai

$$
v_{c}\left(0^{-}\right)=\frac{1}{C} \int_{-\infty}^{0^{-}} i(\tau) d \tau=v_{0} .
$$

Tuo būdu (3.46) lygtis pavirsta tokia:

$$
\left(R+\frac{1}{C s}\right) I(s)+\frac{v_{0}}{S}=\frac{V}{S} .
$$

Išsprendus šią lygti $I(s)$ atžvilgiu, gaunama:

$$
I(s)=\frac{V-v_{0}}{s} \frac{1}{R+1 / C s}=\frac{V-v_{0}}{R} \frac{1}{s+1 / R C} .
$$

$I(s)$ pritaikius atvirkštinę Laplaso transformaciją,

$$
i(t)=\frac{V-v_{0}}{R} e^{-t / R C} u(t) .
$$

3.7. Apskaičiuokite 3.8 a pav. pavaizduotos grandinès kompleksinę iejjimo varžą $Z(s)$. Visų grandinès elementų vertès nurodytos omais. Atsakymą patikrinkite MATLAB paketu.

\section{Sprendimas}

Norėdami palengvinti analizės uždavini pradinę grandinę pakeičiame ekvivalentine grandine, pavaizduota $3.8 \mathrm{~b}$ pav. 


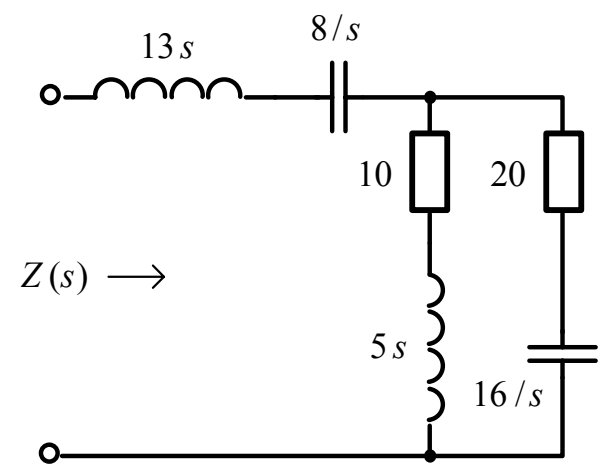

a)

Ekvivalentinę grandinę sudaro tokios varžos:

$$
\begin{gathered}
Z_{1}=13 s+\frac{8}{s}=\frac{13 s^{2}+8}{s}, \quad Z_{2}=10+5 s, \\
Z_{3}=20+\frac{16}{s}=\frac{4(5 s+4)}{s} .
\end{gathered}
$$

Tuomet

$$
\begin{aligned}
Z(s)= & Z_{1}+\frac{Z_{2} Z_{3}}{Z_{2}+Z_{3}}=\frac{13 s^{2}+8}{s}+\frac{20\left(5 s^{2}+14 s+8\right)}{5 s^{2}+30 s+16} \\
= & \frac{65 s^{4}+490 s^{3}+528 s^{2}+400 s+128}{s\left(5 s^{2}+30 s+16\right)} .
\end{aligned}
$$

Tikriname atsakymą MATLAB paketu:

syms s; \% Apibrèžiame simbolini kintamajji s

$z 1=13 * s+8 / s ; z 2=5^{*} s+10 ; z 3=20+16 / s ;$

$\mathrm{z}=\mathrm{z} 1+\mathrm{z2} * \mathrm{z3} /(\mathrm{z} 2+\mathrm{z} 3)$

$\mathrm{z}=$ 
$13 * s+8 / s+(5 * s+10) *(20+16 / s) /(5 * s+30+16 / s)$

$\mathrm{z} 10=\operatorname{simplify}(\mathrm{z})$

$\mathrm{z} 10=$

$\left(65{ }^{\star} S^{\wedge} 4+490 * S^{\wedge} 3+528 * S^{\wedge} 2+400 * S+128\right) / s /\left(5 * S^{\wedge} 2+30 * S+16\right)$

Taigi skaičiavimai atlikti teisingai.

\subsection{Uždaviniai}

3.8. Duotas baigtinès trukmès signalas $x(t)$, kuris apibrèžiamas taip:

$$
x(t) \begin{cases}\neq 0 & t_{1} \leq t \leq t_{2} \\ =0 & t<t_{1}, \quad t>t_{2},\end{cases}
$$

čia $t_{1}$ ir $t_{2}$ - baigtinès vertès. Jei esant bent vienai $s$ vertei $X(s)$ konverguoja, tai $X(s)$ konvergavimo sritis - visa $s$ plokštuma. Irodykite ši teiginị.

3.9. Tarkime, $\mathrm{kad}$

$$
x(t)=\left\{\begin{array}{lc}
e^{-a t} & 0 \leq t \leq T \\
0 & t<0, \quad t>T
\end{array} .\right.
$$

Raskite $x(t)$ Laplaso transformaciją.

Ats. $\frac{1}{s+a}\left[1-e^{-(s+a) T}\right] \quad$ visoms $s$.

3.10. Raskite tokių signalų Laplaso transformacijas $X(s)$ ir nubraižykite polių bei nulių diagramas kartu su konvergavimo sritimis: 
(a) $x(t)=e^{-2 t} u(t)+e^{-3 t} u(t)$;

(b) $x(t)=e^{-3 t} u(t)+e^{2 t} u(-t)$;

(c) $x(t)=e^{2 t} u(t)+e^{-3 t} u(-t)$.

Ats. (a) $\frac{2\left(s+\frac{5}{2}\right)}{(s+2)(s+3)} \quad \operatorname{Re}(s)>-2$;

(b) $\frac{-5}{(s-2)(s+3)} \quad-3<\operatorname{Re}(\mathrm{s})<2$;

(c) $X(s)$ neegzistuoja.

3.11. Tarkime, kad

$$
x(t)=e^{-a|t|} .
$$

Raskite $X(s)$ ir nubraižykite polių bei nulių diagramą kartu su konvergavimo sritimi, kai $a>0$ ir $a<0$.

$$
\begin{aligned}
\text { Ats. } & \frac{-2 a}{s^{2}-a^{2}} \quad a>0,-a<\operatorname{Re}(s)<a ; \\
& X(s) \text { neegzistuoja, kai } a<0 .
\end{aligned}
$$

3.12. Raskite tokių signalų Laplaso transformacijas ir konvergavimo sritis:

(a) $x(t)=\delta\left(t-t_{0}\right)$

(b) $x(t)=u\left(t-t_{0}\right)$;

(c) $x(t)=e^{-2 t}[(u(t)-u(t-5)]$; 
(d) $x(t)=\sum_{k=0}^{\infty} \delta(t-k T)$;

(e) $x(t)=\delta(a t+b), \quad a, b-$ realiosios konstantos.

Ats. (a) $e^{-s t_{0}}$ visoms $s$; (b) $\frac{e^{-s t_{0}}}{s} \quad \operatorname{Re}(s)>0$;

(c) $\frac{1}{s+2}\left[1-e^{-5(s+2)}\right] \quad \operatorname{Re}(s)>-2$;

(d) $\frac{1}{1-e^{-s T}} \operatorname{Re}(s)>0$; (e) $\frac{1}{|a|} e^{s b / a}$ visoms $s$.

3.13. Pasinaudodami Laplaso transformacijos savybèmis, iš $u(t)$ Laplaso transformacijos išveskite šių signalų Laplaso transformacijas:

(a) $t u(t)$;

(b) $e^{-a t} u(t)$;

(c) $t e^{-a t} u(t)$;

(d) $e^{-a t} \cos \omega_{0} t u(t)$.

Ats. (a) $\frac{1}{s^{2}} \operatorname{Re}(s)>0$; (b) $\frac{1}{s+a} \quad \operatorname{Re}(s)>-a$;
(c) $\frac{1}{(s+a)^{2}} \operatorname{Re}(s)>-a$;
(d) $\frac{s+a}{(s+a)^{2}+\omega_{0}^{2}} \operatorname{Re}(s)>-a$.

3.14. Raskite šių $X(s)$ atvirkštines Laplaso transformacijas:

(a) $X(s)=\frac{1}{s+1}, \quad \operatorname{Re}(s)<-1$;

(b) $X(s)=\frac{s}{s^{2}+4}, \quad \operatorname{Re}(s)>0$;

(c) $X(s)=\frac{s+1}{(s+1)^{2}+4}, \quad \operatorname{Re}(s)>-1$. 
Ats. (a) $-e^{-t} u(-t)$; (b) $\cos 2 t u(t)$; (c) $e^{-t} \cos 2 t u(t)$.

3.15. Raskite šiu $X(s)$ atvirkštines Laplaso transformacijas:

(a) $X(s)=\frac{2 s+4}{s^{2}+4 s+3}, \operatorname{Re}(s)<-3$;

(b) $X(s)=\frac{2 s+4}{s^{2}+4 s+3}, \quad-3<\operatorname{Re}(s)<-1$;

Ats. (a) $-\left(e^{-t}+e^{-3 t}\right) u(-t)$; (b) $-e^{-t} u(-t)+e^{-3 t} u(t)$.

3.16. Raskite $X(s)$ atvirkštinę Laplaso transformaciją:

$$
\begin{aligned}
& X(s)=\frac{5 s+13}{s\left(s^{2}+4 s+13\right)}, \quad \operatorname{Re}(s)>0 . \\
& \text { Ats. }\left[1-e^{-2 t}(\cos 3 t-\sin 3 t)\right] u(t) .
\end{aligned}
$$

3.17. Raskite $X(s)$ atvirkštinę Laplaso transformaciją:

$$
\begin{aligned}
& X(s)=\frac{s^{2}+2 s+5}{(s+3)(s+5)^{2}}, \quad \operatorname{Re}(s)>-3 . \\
& \text { Ats. }\left[2 e^{-3 t}-e^{-5 t}-10 t e^{-5 t}\right] u(t) .
\end{aligned}
$$

3.18. Raskite šiu $X(s)$ atvirkštines Laplaso transformacijas:

(a) $X(s)=\frac{2 s+1}{s+2}, \quad \operatorname{Re}(s)>-2$;

(b) $X(s)=\frac{s^{2}+6 s+7}{s^{2}+3 s+2}, \quad \operatorname{Re}(s)>-1$;

(c) $X(s)=\frac{s^{2}+6 s+7}{s^{2}+3 s+2}, \quad \operatorname{Re}(s)>-1$. 

Ats. (a) $2 \delta(t)-3 e^{-2 t} u(t)$;
(b) $\delta(t)+\left(2 e^{-t}+e^{-2 t}\right) u(t)$;
(c) $\delta^{\prime}(t)-\delta(t)+\left(2+e^{-3 t}\right) u(t)$.

3.19. Raskite $X(s)$ atvirkštinę Laplaso transformaciją:

$$
\begin{aligned}
& X(s)=\frac{2+2 s e^{-2 s}+4 e^{-4 s}}{s^{2}+4 s+3}, \quad \operatorname{Re}(s)>-1 . \\
& \text { Ats. } \quad\left(e^{-t}-e^{-3 t}\right) u(t)+\left[-e^{-(t-2)}+3 e^{-3(t-2)}\right] u(t-2) \\
& \quad+2\left[e^{-(t-4)}-e^{-3(t-4)}\right] u(t-4) .
\end{aligned}
$$

3.20. Pakartokite 2.5 uždavinị, pasinaudodami Laplaso transformacija.

3.21. Tolydinès tiesinès stacionariosios sistemos išèjimo signalas $y(t)$ lygus $2 e^{-3 t} u(t)$, esant iejjimo signalui $x(t)=u(t)$.

(a) Raskite sistemos impulsinę charakteristiką $h(t)$.

(b) Raskite išejimo signalą, esant iejjimo signalui $x(t)=e^{-t} u(t)$
Ats.
(a) $2 \delta(t)-6 e^{-3 t} u(t)$;
(b) $\left(-e^{-t}+3 e^{-3 t}\right) u(t)$.

3.22. Pakartokite 2.12 uždavini, pasinaudodami Laplaso transformacija.

3.23. Pakartokite 2.21 uždavini, pasinaudodami Laplaso transformacija.

3.24. Pakartokite 2.23 uždavini, pasinaudodami Laplaso transformacija.

3.25. Duota tolydinè tiesinè stacionarioji sistema, kurios iejimo signalas $x(t)$ ir išèjimo signalas $y(t)$ susiję taip:

$$
y^{\prime \prime}(t)+y^{\prime}(t)-2 y(t)=x(t) .
$$

(a) Raskite sistemos funkciją $H(s)$. 
(b) Raskite impulsinę charakteristiką $h(t)$, kai sistema: (i) yra priežastinè, (ii) yra stabilioji, (iii) nèra nei priežastinè, nei stabilioji.

$$
\begin{aligned}
& \text { Ats. (a) } \frac{1}{(s+2)(s-1)} ; \text { (b) }-\frac{1}{3}\left(e^{-2 t}-e^{t}\right) u(t) \text {; } \\
& -\frac{1}{3} e^{-2 t} u(t)-\frac{1}{3} e^{t} u(-t) ; \quad \frac{1}{3} e^{-2 t} u(-t)-\frac{1}{3} e^{t} u(-t) .
\end{aligned}
$$

3.26. Dvi priežastinès posistemès, kuriu sistemos funkcijos $F(s)$ ir $G(s)$, sujungtos grižtamuoju ryšiu i sistemą, pavaizduotą 3.9 pav. Raskite tokio junginio sistemos funkciją $H(s)$.

$$
\text { Ats. } \frac{F(s)}{1-F(s) G(s)} \text {. }
$$

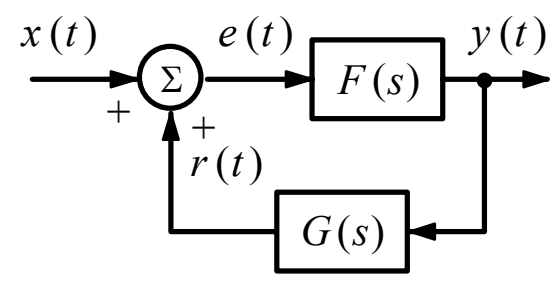

3.9 pav.

3.27. (a) Irodykite, kad abipuse $x(t)$ Laplaso transformaciją galima apskaičiuoti iš dviejų vienpusių Laplaso transformacijų.

(b) Pasinaudodami (a) dalyje gautu rezultatu, raskite $e^{-2|t|}$ Laplaso transformaciją.

$$
\text { Ats. (b) }-\frac{4}{s^{2}-4} \quad-2<\operatorname{Re}(s)<2 \text {. }
$$


3.28. Irodykite, kad:

(a) $x\left(0^{+}\right)=\lim _{s \rightarrow \infty} s X_{I}(s)$;

(b) $\lim _{t \rightarrow \infty} x(t)=\lim _{s \rightarrow 0} s X_{I}(s)$.

3.29. Pakartokite 2.18 uždavini, pasinaudodami vienpuse Laplaso transformacija.

3.30. Išspręskite antrosios eilès tiesinę diferencialinę lygti

$$
y^{\prime \prime}(t)+5 y^{\prime}(t)+6 y(t)=x(t)
$$

esant pradinèms salygoms $y(0)=2, y^{\prime}(0)=1$. Iejjimo signalas $x(t)=e^{-t} u(t)$. Ats. $\frac{1}{2} e^{-t}+6 e^{-2 t}-\frac{9}{2} e^{-3 t} \quad t \geq 0$.

3.31. Pakartokite 3.6 uždavini. vietoi $i(t)$ ieškodami $v_{c}(t)$. Ats. $V\left(1-e^{-t / R C}\right)+v_{0} e^{-t / R C} \quad t \geq 0$.

3.32. Pakartokite 3.6 uždavini, taikydami transformuotujų grandinių metodą.

3.33. Grandineje, pavaizduotoje 3.10 pav., jungiklis ilgą laiką buvo ijungtas, prieš ji išjungiant momentu $t=0$. Raskite rite tekančią srovę $i(t)$, kai $t \geq 0$.

Ats. $e^{-2 t}\left(2 \cos 6 t-\frac{2}{3} \sin 6 t\right)$. 


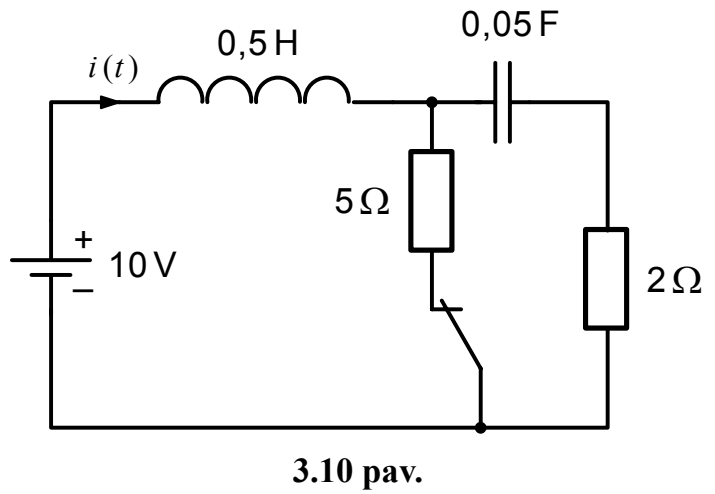

3.34. Grandinëje, pavaizduotoje 3.11 pav., abu jungikliai ijungiami tuo pačiu momentu $t=0$. Kondensatoriu $C_{1}$ ir $C_{2}$ itampos, prieš ijungiant jungiklius, lygios atitinkamai $1 \mathrm{~V}$ ir $2 \mathrm{~V}$.

(a) Raskite sroves $i_{1}(t)$ ir $i_{2}(t)$.

(b) Raskite kondensatorių itampas momentu $t=0^{+}$.

Ats. (a) $i_{1}(t)=\delta(t)+\frac{3}{4} e^{-t / 4} u(t) ; \quad i_{2}(t)=\delta(t)-\frac{3}{4} e^{-t / 4} u(t)$;

(b) $v_{C_{1}}\left(0^{+}\right)=2 \mathrm{~V} ; \quad v_{C_{2}}\left(0^{+}\right)=3 \mathrm{~V}$.

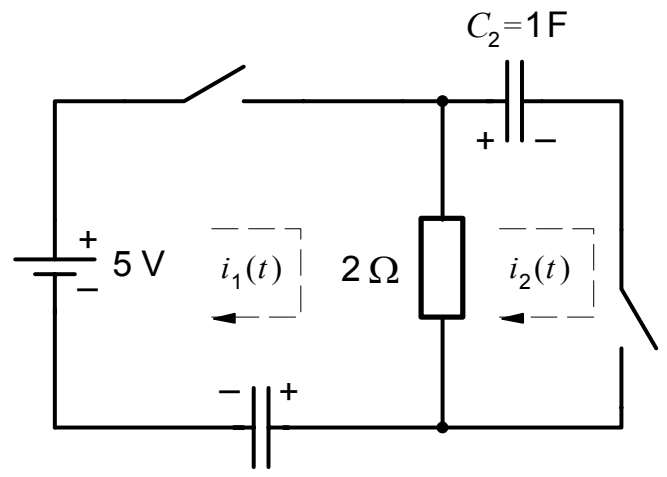

3.11 pav. 


\section{SPEKTRINE் TOLYDINIŲ SIGNALŲ IR SISTEMŲ ANALIZE்}

\subsection{Ivadas}

Trečiajame skyriuje buvo pristatyta Laplaso transformacija, dèl kurios signalai iš laiko srities perkeliami i kompleksinio dažnio sriti. Kaip jau išsiaiškinome, naudojant Laplaso transformacijas daugeliu atvejų ne tik lengviau yra nagrinèti, bet ir atskleidžiama daugiau detalių apie signalų ir sistemų pobūdi bei savybes. Šiame skyriuje susipažinsime su Furjè transformacija, leidžiančia signalus vaizduoti jų spektrais. Be to, spektrinè (arba Furjè) analizė svarbi apibūdinant tam tikrų tipų sistemas ir jų savybes dažnio srityje.

\subsection{Periodinių signalų vaizdavimas Furjẻ eilute}

\section{Kompleksinės eksponentės išraiška}

Periodinio signalo $x(t)$, kurio periodas $-T_{0}$, skleidinys kompleksinès eksponentės Furjè eilute užrašomas taip:

$$
x(t)=\sum_{k=-\infty}^{\infty} c_{k} e^{j k \omega_{0} t}, \quad \omega_{0}=\frac{2 \pi}{T_{0}},
$$

čia $c_{k}$-kompleksiniai Furjë koeficientai, randami pagal:

$$
c_{k}=\frac{1}{T_{0}} \int_{-T_{0} / 2}^{T_{0} / 2} x(t) e^{-j k \omega_{0} t} d t .
$$

(4.2) lygtyje $k$ prilyginus 0 , 


$$
c_{0}=\frac{1}{T_{0}} \int_{-T_{0} / 2}^{T_{0} / 2} x(t) d t .
$$

Taigi $c_{0}$ lygus vidutinei $x(t)$ vertei per periodą.

\section{Trigonometrinė išraiška}

Trigonometrinè Furjè eilutès išraiška yra tokia:

$$
x(t)=\frac{a_{0}}{2}+\sum_{k=1}^{\infty}\left(a_{k} \cos k \omega_{0} t+b_{k} \sin k \omega_{0} t\right),
$$

čia $a_{k}$ ir $b_{k}$ - Furjè koeficientai, randami pagal:

$$
\begin{gathered}
a_{k}=\frac{2}{T_{0}} \int_{-T_{0} / 2}^{T_{0} / 2} x(t) \cos k \omega_{0} t d t, \\
b_{k}=\frac{2}{T_{0}} \int_{-T_{0} / 2}^{T_{0} / 2} x(t) \sin k \omega_{0} t d t .
\end{gathered}
$$

Jei periodinis signalas $x(t)$ yra lyginis, $b_{k}=0$ ir tokio signalo Furjè eilutèje (4.4) yra tik nariai su kosinuso funkcija:

$$
x(t)=\frac{a_{0}}{2}+\sum_{k=1}^{\infty} a_{k} \cos k \omega_{0} t .
$$

Esant nelyginiam signalui $x(t), a_{k}=0$, todèl tokio signalo Furjè eiluteje yra tik nariai su sinuso funkcija:

$$
x(t)=\sum_{k=1}^{\infty} b_{k} \sin k \omega_{0} t .
$$




\subsection{Furjè transformacija}

\section{Apibrèžimas}

Signalu ir sistemų teorijos vadovèliuose įrodoma, kad baigtinès trukmès aperiodinio signalo $x(t)$ (t. y. tokio, kurio periodas $T_{0} \rightarrow \infty$ ) skleidinys Furjè eilute virsta integralu, vadinamu Furjè transformacija:

$$
X(\omega)=\int_{-\infty}^{\infty} x(t) e^{-j \omega t} d t .
$$

$\mathrm{O}$ atvirkštinè Furjè transformacija apibrěžiama taip:

$$
x(t)=\frac{1}{2 \pi} \int_{-\infty}^{\infty} X(\omega) e^{j \omega t} d \omega .
$$

Sakoma, kad $x(t)$ ir $X(\omega)$ sudaro Furje transformacijos porą:

$$
x(t) \leftrightarrow X(\omega) .
$$

\section{Furjè spektrai}

Aperiodinio signalo $x(t)$ Furjè transformacija $X(\omega)$ bendruoju atveju yra kompleksinis dydis, kurią galima užrašyti taip:

$$
X(\omega)=|X(\omega)| e^{j \phi(\omega)} .
$$

Dydis $|X(\omega)|$ vadinamas $x(t)$ amplitudžių spektru, o dydis $\phi(\omega)-x(t)$ fazių spektru.

Jei $x(t)$ yra realusis signalas, tai remiantis (4.8) lygtimi, 


$$
X(-\omega)=\int_{-\infty}^{\infty} x(t) e^{j \omega t} d t
$$

Iš to matyti, kad:

$$
\begin{gathered}
X(-\omega)=X^{*}(\omega), \\
|X(-\omega)|=|X(\omega)|, \quad \phi(-\omega)=-\phi(\omega) .
\end{gathered}
$$

Taigi amplitudžių spektras $|X(\omega)|$ yra lyginè $\omega$ funkcija, o fazių spektras $\phi(\omega)$ - nelyginè.

\section{Ryšys tarp Furjè ir Laplaso transformacijų}

Pagal (4.8) lygti $x(t)$ Furjė transformacija apibrèžiama taip:

$$
X(\omega)=\int_{-\infty}^{\infty} x(t) e^{-j \omega t} d t
$$

O pagal (3.3) lygti $x(t)$ dvipusė Laplaso transformacija yra:

$$
X(s)=\int_{-\infty}^{\infty} x(t) e^{-s t} d t
$$

Palyginus (4.14) ir (4.15) lygtis, matyti, kad Furjè transformacija yra atskiras Laplaso transformacijos atvejis, kai $s=j \omega$. Kitaip tariant, Laplaso transformacija gali būti laikoma Furjè transforma-

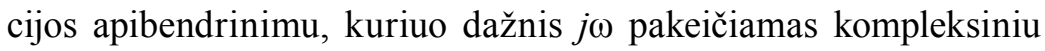
kintamuoju $s=\sigma+j \omega$. Šis kintamasis dažnai vadinamas kompleksiniu dažniu. 


\subsection{Tolydinès Furjè transformacijos savybès}

Furjè transformacijos savybès panašios i Laplaso transformacijos (žr. 3.4 poskyri). Pagrindinès savybès pateiktos 4.1 lentelëje, o kai kurių dažniau sutinkamų signalų Furjẻ transformacijos 4.2 lentelëje.

Beje, daugelio signalu Furjè transformacija galima rasti ir be standartinių transformacijų lentelès - tiesiog naudojant MATLAB paketą. Pavyzdžiui, norint sužinoti šuolinès funkcijos Furjè transformaciją, galima pasinaudoti tokia komanda:

syms $\mathrm{t} v \mathrm{w} \mathrm{x} ; \mathrm{u} 0=\operatorname{sym}\left({ }^{-H e a v i s i d e}(\mathrm{t})^{\prime}\right) ; \mathrm{Fw}=$ fourier($(\mathrm{u} 0)$.

Ivykdžius šią komandą, MATLAB pateikia tokị atsakymą: $\mathrm{FW}=$ $\mathrm{pi} \operatorname{Dirac}_{(\mathrm{w})}-\mathrm{i} / \mathrm{w}$. 
4.1 lentelė. Furjè transformacijos savybès

\begin{tabular}{|c|c|c|}
\hline Savybè & Signalas & Transformacija \\
\hline & $x(t)$ & $X(\omega)$ \\
\hline & $x_{1}(t)$ & $X_{1}(\omega)$ \\
\hline & $x_{2}(t)$ & $X_{2}(\omega)$ \\
\hline Tiesiškumas & $a_{1} x_{1}(t)+a_{2} x_{2}(t)$ & $a_{1} X_{1}(s)+a_{2} X_{2}(s)$ \\
\hline $\begin{array}{l}\text { Postūmis tam tikru } \\
\text { laiku }\end{array}$ & $x\left(t-t_{0}\right)$ & $e^{-j \omega t_{0}} X(\omega)$ \\
\hline Postūmis dažnio ašyje & $e^{j \omega_{0} t} x(t)$ & $X\left(\omega-\omega_{0}\right)$ \\
\hline $\begin{array}{l}\text { Laiko ašies mastelio } \\
\text { keitimas }\end{array}$ & $x(a t)$ & $\frac{1}{|a|} X\left(\frac{\omega}{a}\right)$ \\
\hline Laiko ašies apvertimas & $x(-t)$ & $X(-\omega)$ \\
\hline Dualumas & $X(t)$ & $2 \pi x(-\omega)$ \\
\hline $\begin{array}{l}\text { Diferencijavimas } t \text { at- } \\
\text { žvilgiu }\end{array}$ & $\frac{d x(t)}{d t}$ & $j \omega X(\omega)$ \\
\hline $\begin{array}{l}\text { Diferencijavimas } \omega \\
\text { atžvilgiu }\end{array}$ & $-j t x(t)$ & $\frac{d X(\omega)}{d \omega}$ \\
\hline Integravimas & $\int_{-\infty}^{t} x(\tau) d \tau$ & $\pi X(0) \delta(\omega)+\frac{1}{j \omega} X(\omega)$ \\
\hline Sąsūka & $x_{1}(t) * x_{2}(t)$ & $X_{1}(\omega) X_{2}(\omega)$ \\
\hline Sandauga & $x_{1}(t) x_{2}(t)$ & $\frac{1}{2 \pi} X_{1}(\omega) * X_{2}(\omega)$ \\
\hline
\end{tabular}


Šis MATLAB užrašas identiškas 4.2 lentelëje pateiktam reiškiniui:

$$
u(t) \leftrightarrow \pi \delta(\omega)+\frac{1}{j \omega} .
$$

4.2 lentelè. Furjè transformacijos poros

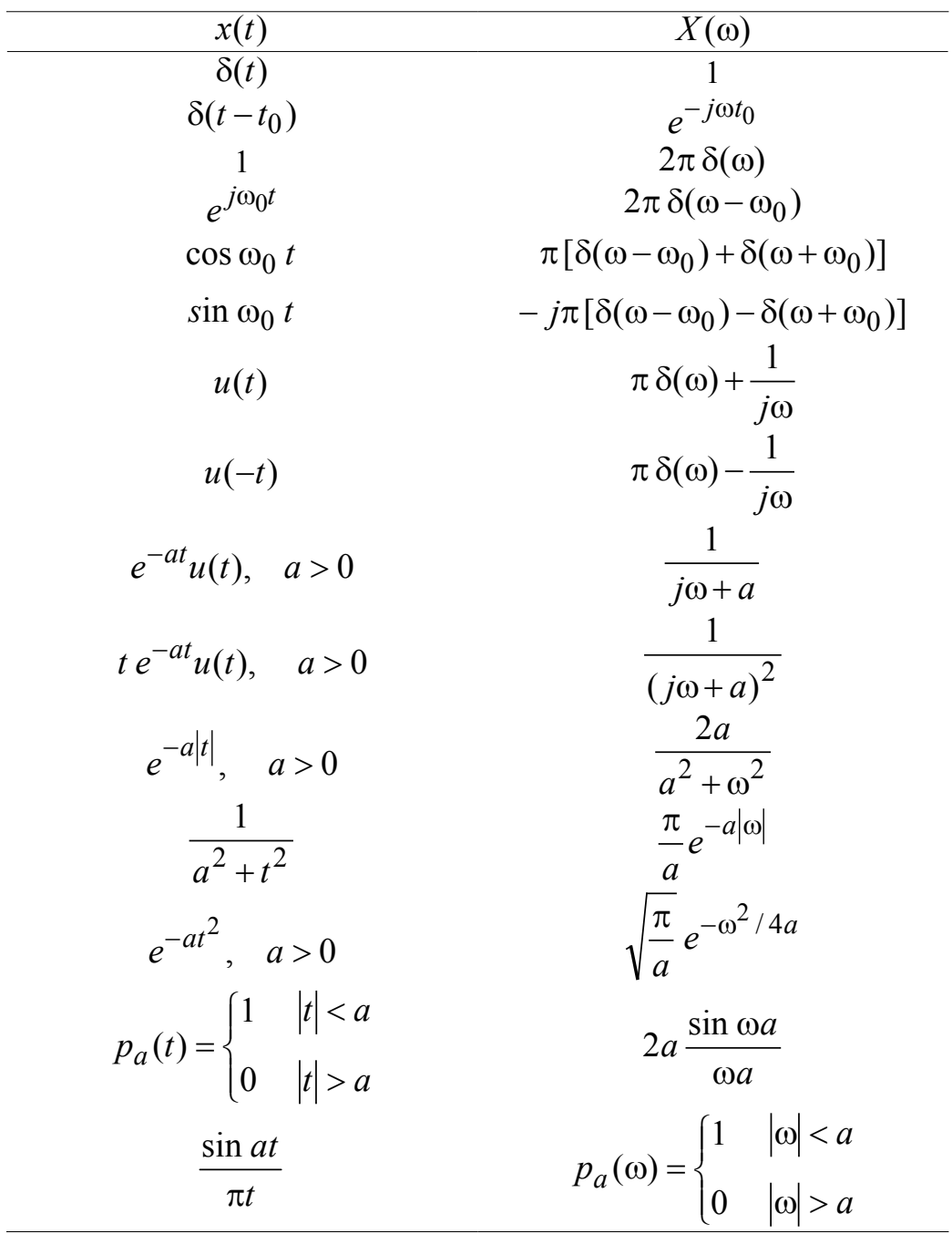




\subsection{Dažninès TSS charakteristikos}

\section{Apibrèžimas}

Kaip aptarta 2.2 poskyryje, tolydinès TSS išejimo signalas $y(t)$ lygus iẹjimo signalo $x(t)$ ir impulsinès charakteristikos $h(t)$ sąsūkai:

$$
y(t)=x(t) * h(t) .
$$

Pritaikius sąsūkos savybę (žr. 4.1 lentelę), gaunama:

$$
Y(\omega)=X(\omega) H(\omega),
$$

čia $Y(\omega), X(\omega)$ ir $H(\omega)$ yra atitinkamai $y(t), x(t)$ ir $h(t)$ Furjè transformacijos. Iš (4.17) lygties matyti, kad

$$
H(\omega)=\frac{Y(\omega)}{X(\omega)} .
$$

Funkcija $H(\omega)$ vadinama sistemos (kompleksine) dažnine charakteristika. Tarkime, kad

$$
H(\omega)=|H(\omega)| e^{j \theta_{H}(\omega)} .
$$

$H(\omega) \mid$ vadinama sistemos dažnine amplitudès charakteristika $(\mathrm{DACh})$, o $\theta_{H}(\omega)$ - dažnine fazès charakteristika (DFCh).

\section{Signalo perdavimas be iškraipymo}

Tam, kad TSS perduotų signalą jo neiškraipydama, reikalaujama, kad sistemos išèjime būtų tiksliai atkurta iẻjimo signalo forma. O signalo amplitudè gali skirtis ir jam leidžiama véluoti. Taigi, jei $x(t)$ yra ièjimo signalas, reikalingas toks išèjimo signalas: 


$$
y(t)=K x\left(t-t_{d}\right)
$$

čia $t_{d}$ - vèlinimas, o $K(>0)$ - stiprinimo koeficientas (konstanta).

Abiem (4.20) lygties pusėms pritaikius Furjè transformacija, gaunama:

$$
Y(\omega)=K e^{-j \omega t} d X(\omega)
$$

Kaip matyti iš (4.17) lygties, norint perduoti signalą be iškraipymo, sistema turi tenkinti tokią sąlygą:

$$
H(\omega)=|H(\omega)| e^{j \theta_{H}(\omega)}=K e^{-j \omega t_{d}} .
$$

Taigi

$$
|H(\omega)|=K, \quad \theta_{H}(\omega)=-j \omega t_{d}
$$

Kitaip tariant, $H(\omega)$ amplitudè turi būti pastovi visame dažnių diapazone, o $H(\omega)$ fazè turi tiesiškai priklausyti nuo dažnio.

\subsection{Uždavinių sprendimo pavyzdžiai}

4.1. Raskite signalo $x(t)=\cos \omega_{0} t$ skleidini kompleksinès eksponentès Furjè eilute.

\section{Sprendimas}

Pritaikius Eulerio formulę, galima užrašyti:

$$
\cos \omega_{0} t=\frac{1}{2}\left(e^{j \omega_{0} t}+e^{-j \omega_{0} t}\right)=\frac{1}{2} e^{-j \omega_{0} t}+\frac{1}{2} e^{j \omega_{0} t}=\sum_{k=-\infty}^{\infty} c_{k} e^{j k \omega_{0} t} .
$$

Taigi signalo $\cos \omega_{0} t$ kompleksiniai Furjè koeficientai yra: 


$$
c_{1}=\frac{1}{2}, \quad c_{-1}=\frac{1}{2}, \quad c_{k}=0, \quad|k| \neq 1 .
$$

Atsakymą galima patikrinti MATLAB paketu, skaičiuojant vidutinę signalo vertę $c_{0}$ ir pirmujų trijų harmonikų koeficientus $c_{1}, c_{2}, c_{3}$. Eksponentinès Furjè eilutès koeficientams rasti galima pasinaudoti MATLAB komanda int( $\mathbf{x}, \mathbf{t}, \mathbf{a}, \mathbf{b})$, kurioje $\mathbf{x}$ žymi integruojamą funkciją, $\mathbf{t}$ yra simbolinio reiškinio kintamasis, a ir b - skaitinès vertès apibrèžtinio integralo rèžiams. Visa MATLAB komanda atrodo taip:

syms t $\quad \%$ Apibréžiame simbolini kintamaji t

$\mathrm{T}=1 ; \quad \%$ Signalo periodas

w0 $=2 * \mathrm{pi} / \mathrm{T} ; \quad \%$ Kampinis dažnis

for $\mathrm{k}=0: 3 \quad \%$ Skaičiuojame nuolatinę dedamają ir tris pirmasias harmonikas

$\mathrm{Ck}=(1 / \mathrm{T}) * \operatorname{int}\left(\cos (\mathrm{w} 0 * \mathrm{t}) * \exp \left(-\mathrm{i}^{*} \mathrm{w}^{*} \mathrm{k} * \mathrm{t}\right), \mathrm{t}, 0,1\right) \%$ Eksponentinè Furjè eilutè, (4.2) sąryšis

end

MATLAB komandiniame lange atsiranda užrašas:

$$
\mathrm{Ck}=0 \quad \mathrm{Ck}=1 / 2 \quad \mathrm{Ck}=0 \quad \mathrm{Ck}=0 .
$$

Šios MATLAB paketo parodytos vertès reiškia, $\operatorname{kad} c_{k}=1 / 2$ yra vienintelè nenuliné spektro dedamoji. Be to, kadangi $\cos \omega_{0} t$ yra lyginè funkcija, visi koeficientai $c_{k}$ yra realieji ir $c_{-k}=c_{k}=1 / 2$. Todèl galima užrašyti:

$$
\begin{gathered}
x(t)=\ldots+0+\frac{1}{2} e^{-j \omega_{0} t}+0+\frac{1}{2} e^{j \omega_{0} t}+0+\ldots \\
=\frac{e^{j \omega_{0} t}+e^{-j \omega_{0} t}}{2}=\cos \omega_{0} t .
\end{gathered}
$$


4.2. Raskite signalo $x(t)=e^{j \omega_{0} t}$ Furjè transformaciją.

\section{Sprendimas}

4.2 lentelejje randame formulę: $\delta(t) \leftrightarrow 1$. Ten pat pateikta formulè ir Furjè transformacijos dualumo savybei apibūdinti:

$$
1 \leftrightarrow 2 \pi \delta(\omega)
$$

Šiai lygčiai pritaikius formulę, nusakančią postūmio dažnio ašyje savybe, gaunama:

$$
e^{j \omega_{0} t} \leftrightarrow 2 \pi \delta\left(\omega-\omega_{0}\right) .
$$

Gautas atsakymas sutampa su atitinkamu įrašu 4.2 lentelèje.

4.3. Duota grandinè, kurios ièjimo ir išèjimo signalai susiję taip:

$$
\frac{d^{2}}{d t^{2}} v_{o}(t)+5 \frac{d}{d t} v_{o}(t)+6 v_{o}(t)=10 v_{i}(t) .
$$

Taikydami Furjè transformacijos metodą, raskite išèjimo signalą $v_{o}(t)$, grandinès ièjime veikiant $v_{i}(t)=2 e^{-t} u(t)$.

\section{Sprendimas}

Abiem (4.24) lygties pusèms pritaikome Furjè transformaciją:

$$
\begin{gathered}
{\left[\left(j \omega^{2}\right)+5 j \omega+6\right] V_{o}(\omega)=10 V_{i}(\omega)=10 \frac{2}{j \omega+1},} \\
V_{o}(\omega)=\frac{20}{(j \omega+1)(j \omega+2)(j \omega+3)} .
\end{gathered}
$$

Skaidos operacijai atlikti, ivedę pakeitimą $j \omega=s$, vykdome tokią MATLAB komandą: 
syms s; $\operatorname{collect}((\mathrm{s}+1) *(\mathrm{~s}+2) *(\mathrm{~s}+3))$

ans $=$

$s^{\wedge} 3+6 * s^{\wedge} 2+11^{\star} s+6$

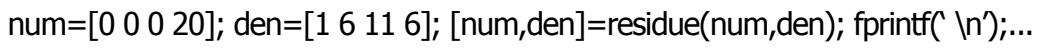
fprintf('r1 = \%4.2f $\left\langle t^{\prime}, \operatorname{num}(1)\right) ;$ fprintf('p1 = \%4.2f', den(1)); fprintf(' $\left.\mid \mathrm{n}^{\prime}\right) ; \ldots$ fprintf(' $\left.r 2=\% 4.2 f \backslash t^{\prime}, \operatorname{num}(2)\right) ;$ fprintf('p2 = \%4.2f', den(2)); fprintf( $\left\langle\mathrm{n}^{\prime}\right) ; \ldots$

fprintf('r3 = \%4.2f $\backslash t^{\prime}$, num(3)); fprintf('p3 = \%4.2f', den(3))

$r 1=10.00 \mathrm{p} 1=-3.00$

$r 2=-20.00 \mathrm{p} 2=-2.00$

$r 3=10.00 \mathrm{p} 3=-1.00$

Taigi (4.25) trupmeną galima išskaidyti taip:

$$
V_{o}(\omega)=\frac{10}{j \omega+1}-\frac{20}{j \omega+2}+\frac{10}{j \omega+3} .
$$

(4.26) lygčiai belieka pritaikyti atvirkštinę Furjè transformaciją:

$$
v_{o}(t)=10 e^{-t}-20 e^{-2 t}+10 e^{-3 t}=10\left(e^{-t}-2 e^{-2 t}+e^{-3 t}\right) u(t) .
$$

4.4. Pasinaudodami Furjè transformacija, išspręskite 2.23 uždavini.

\section{Sprendimas}

Sistema aprašoma tokia diferencialine lygtimi:

$$
y^{\prime}(t)+2 y(t)=x(t)+x^{\prime}(t)
$$

Šiai lygčiai pritaikius Furjè transformacijos formules, gaunama:

$$
j \omega Y(\omega)+2 Y(\omega)=X(\omega)+j \omega X(\omega) .
$$


Remiantis (4.18) formule, kompleksinė dažninė charakteristika $H(\omega)$ yra:

$$
H(\omega)=\frac{Y(\omega)}{X(\omega)}=\frac{1+j \omega}{2+j \omega}=\frac{2+j \omega-1}{2+j \omega}=1-\frac{1}{2+j \omega} .
$$

$H(\omega)$ pritaikius atvirkštinę Furjè transformaciją, gaunama tokia impulsinè charakteristika:

$$
h(t)=\delta(t)-e^{-2 t} u(t) .
$$

4.5. Apskaičiuokite 4.1 pav. pavaizduotos grandinès perdavimo funkciją $G(s)$, jei $R_{1}=200 \mathrm{k} \Omega, R_{2}=40 \mathrm{k} \Omega, R_{3}=50 \mathrm{k} \Omega, C_{1}=25 \mathrm{nF}$, $C_{2}=10 \mathrm{nF}$. Kompleksini kintamajji s pakeitę $j \omega$, nubraižykite grandinès DACh.

\section{Sprendimas}

Pradinę grandinę pakeitę ekvivalentine grandine kompleksinio dažnio $s$ srityje (4.2 pav.), sudarome mazginiu itampu lygtis mazgams 1 ir 2:

$$
\begin{gathered}
\frac{V_{1}(s)-V_{i}(s)}{R_{1}}+\frac{V_{1}}{1 / s C_{1}}+\frac{V_{1}(s)-V_{o}(s)}{R_{2}}+\frac{V_{1}(s)-V_{2}(s)}{R_{3}}=0, \\
\frac{V_{2}(s)-V_{1}(s)}{R_{3}}=\frac{V_{o}(s)}{1 / s C_{2}} .
\end{gathered}
$$




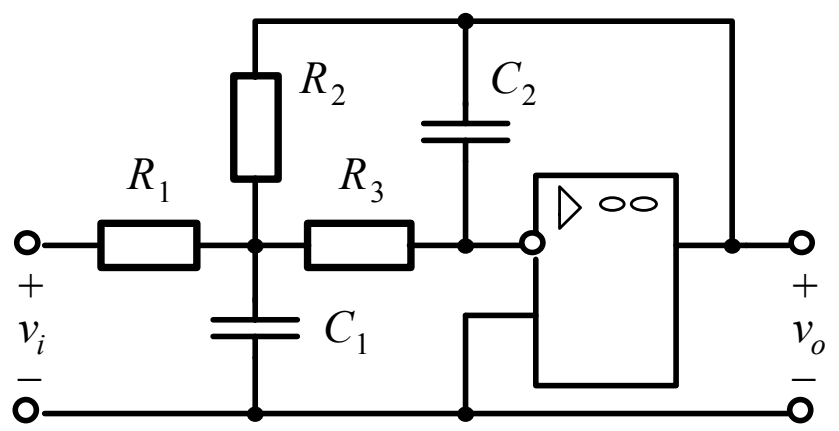

4.1 pav. Pradinė grandinè

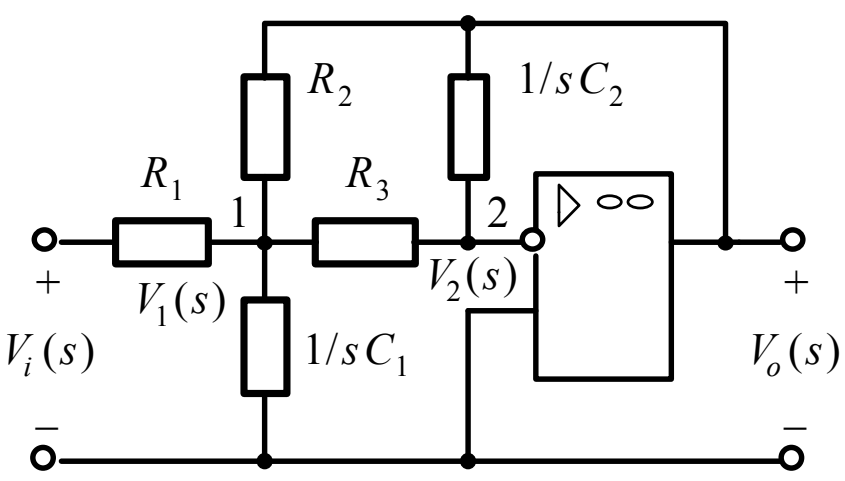

4.2 pav. Transformuotoji grandinè

Kadangi $V_{2}(s)=0$, (4.28) lygti galima perrašyti taip:

$$
V_{1}(s)=\left(-s R_{3} C_{2}\right) V_{o}(s) .
$$

(4.29) lygti istatę i (4.27), pertvarkę ir sutraukę panašius narius, gauname:

$$
\left[\left(\frac{1}{R_{1}}+\frac{1}{R_{2}}+\frac{1}{R_{3}}+s C_{1}\right)\left(-s R_{3} C_{2}\right)-\frac{1}{R_{2}}\right] V_{o}(s)=\frac{1}{R_{1}} V_{i}(s) .
$$


Taigi

$$
\frac{V_{o}(s)}{V_{i}(s)}=\frac{-1}{R_{1}\left[\left(1 / R_{1}+1 / R_{2}+1 / R_{3}+s C_{1}\right)\left(s R_{3} C_{2}\right)+1 / R_{2}\right]} .
$$

Trupmenos (4.30) lygtyje vardikliui supaprastinti galima ivvykdyti tokią MATLAB komandą:

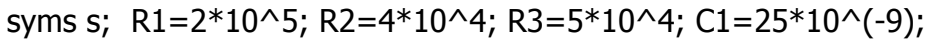

$C 2=10^{*} 10^{\wedge}(-9)$;

$\mathrm{Ds}=\mathrm{R} 1 *\left(\left(1 / \mathrm{R} 1+1 / \mathrm{R} 2+1 / \mathrm{R} 3+\mathrm{s}^{*} \mathrm{C} 1\right) *(\mathrm{~s} * \mathrm{R} 3 * \mathrm{C} 2)+1 / \mathrm{R} 2\right) ; \operatorname{simplify}(\mathrm{Ds})$

ans $=$

$1 / 200 * s+188894659314785825 /$

$75557863725914323419136{ }^{*} s^{\wedge} 2+5$

Supaprastiname koeficientą prie $s^{2}$ :

$188894659314785825 / 75557863725914323419136$

ans $=$

$2.5000 e-006$

$1 / 200 \%$ Supaprastiname koeficientą prie $\mathrm{s}^{\wedge} 2$

ans $=$

0.0050

Dabar perdavimo funkciją galima užrašyti taip:

$$
G(s)=\frac{V_{o}(s)}{V_{i}(s)}=\frac{-1}{2,5 \times 10^{-6} s^{2}+5 \times 10^{-3} s+5} .
$$

Kintamaji $s$ pakeitus $j \omega$, 


$$
G(j \omega)=\frac{V_{o}(j \omega)}{V_{i}(j \omega)}=\frac{-1}{2,5 \times 10^{-6} \omega^{2}-j 5 \times 10^{-3} \omega+5} .
$$

Grandinès DACh (t. y. perdavimo funkcijos $G(j \omega)$ modulio priklausomybės nuo kampinio dažnio $\omega$ ) grafikui nubraižyti vykdome šią MATLAB komandą:

$\mathrm{W}=1: 10: 10000 ; \mathrm{Gs}=-1 . /$

$\left(2.5 \cdot{ }^{*} 10 . \wedge(-6) . *{ }^{*} \cdot{ }^{\wedge} 2-5 \cdot * j . * 10 . \wedge(-3) . * w+5\right) ; \ldots$

semilogx(w,abs(Gs)); xlabel('w'); ylabel('|Vo/Vi|'); grid

DACh grafikas pateiktas 4.3 pav. Iš jo matyti, kad duotoji grandinè su operaciniu stiprintuvu yra antrosios eilès žemutinių dažnių filtras, kurio ribinis kampinis dažnis apytiksliai lygus $700 \mathrm{rad} / \mathrm{s}$.

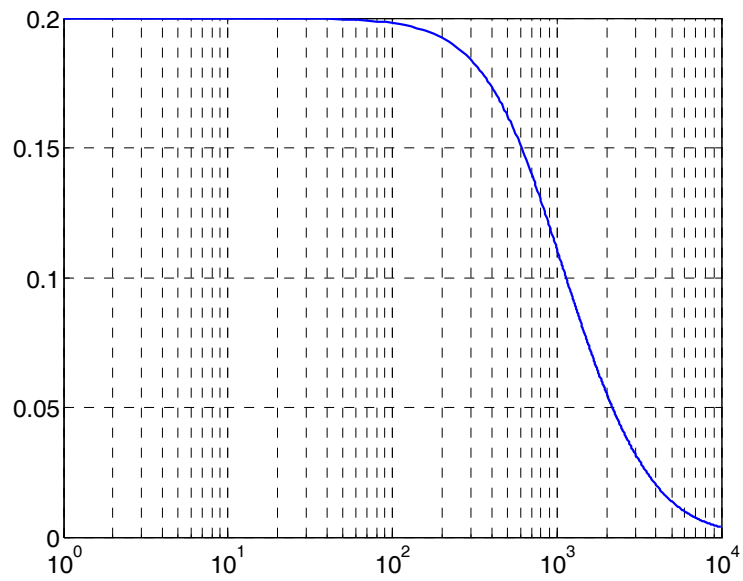

4.3 pav. Grandinès DACh 


\subsection{Uždaviniai}

4.6. Raskite šių signalų skleidinius kompleksinès eksponentès Furjè eilute:

(a) $x(t)=\sin \omega_{0} t$

(b) $x(t)=\cos \left(2 t+\frac{\pi}{4}\right)$;

(c) $x(t)=\cos 4 t+\sin 6 t$;

(d) $x(t)=\sin ^{2} t$.

Ats. (a) $\sum_{k=-\infty}^{\infty} c_{k} e^{j k \omega_{0} t}, \quad c_{1}=\frac{1}{2 j}, \quad c_{-1}=-\frac{1}{2 j}, \quad c_{k}=0,|k| \neq 1$;

(b) $\quad \sum_{k=-\infty}^{\infty} c_{k} e^{j 2 k t}, c_{1}=\frac{\sqrt{2}}{4}(1+j), c_{-1}=\frac{\sqrt{2}}{4}(1-j), c_{k}=0,|k| \neq 1$;

(c)

$$
\sum_{k=-\infty}^{\infty} c_{k} e^{j 2 k t}, c_{-3}=-\frac{1}{2 j}, c_{-2}=c_{2}=\frac{1}{2}, c_{3}=\frac{1}{2 j}, \text { kiti } c_{k}=0
$$

(d) $\quad \sum_{k=-\infty}^{\infty} c_{k} e^{j 2 k t}, c_{-1}=c_{1}=-\frac{1}{4}, c_{0}=\frac{1}{2}$, kiti $c_{k}=0$.

4.7. Periodinių stačiakampių impulsų sekai $x(t)$, pavaizduotai 4.4 pav., apskaičiuokite:

(a) $x(t)$ skleidinị kompleksinès eksponentès Furjè eilute;

(b) $x(t)$ skleidini trigonometrine Furjè eilute. 
Ats. (a) $\frac{A}{2}+\frac{A}{j \pi} \sum_{m=-\infty}^{\infty} \frac{1}{2 m+1} e^{j(2 m+1) \omega_{0} t}$;

(b) $\frac{A}{2}+\frac{2 A}{\pi}\left(\sin \omega_{0} t+\frac{1}{3} \sin 3 \omega_{0} t+\frac{1}{5} \sin 5 \omega_{0} t+\cdots\right)$.

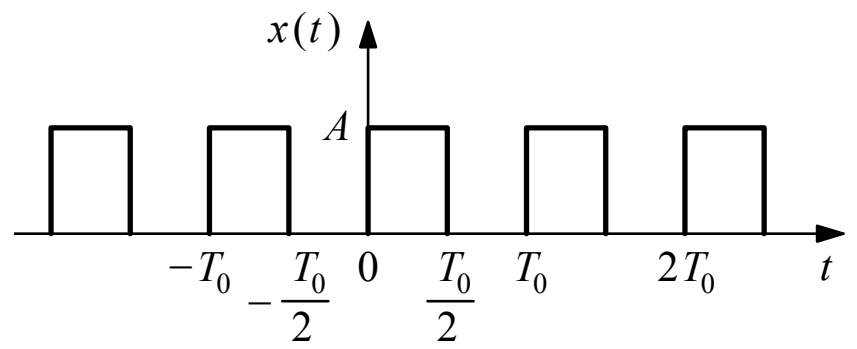

4.4 pav.

4.8. Periodinių stačiakampių impulsų sekai $x(t)$, pavaizduotai 4.5 pav., apskaičiuokite:

(a) $x(t)$ skleidini kompleksinès eksponentès Furjè eilute;

(b) $x(t)$ skleidini trigonometrine Furjè eilute.

Ats. (a) $\frac{A}{2}+\frac{A}{\pi} \sum_{m=-\infty}^{\infty} \frac{(-1)^{m}}{2 m+1} e^{j(2 m+1) \omega_{0} t} ;$
(b) $\frac{A}{2}+\frac{2 A}{\pi}\left(\cos \omega_{0} t-\frac{1}{3} \cos 3 \omega_{0} t+\frac{1}{5} \cos 5 \omega_{0} t-\cdots\right)$. 


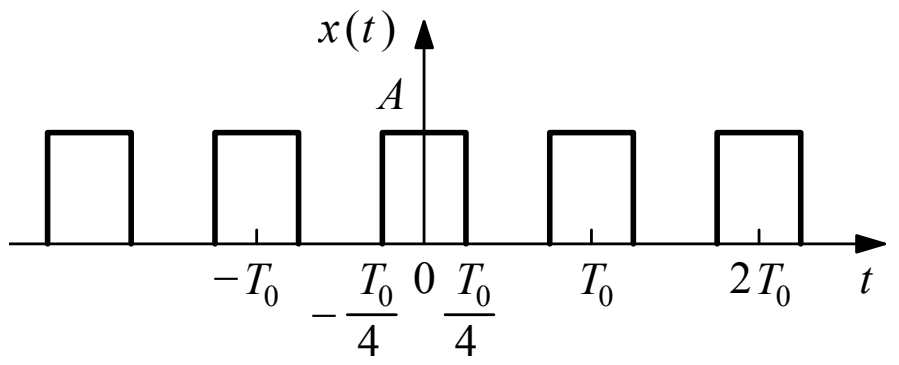

4.5 pav.

4.9. Periodiniu stačiakampių impulsų sekai $x(t)$, pavaizduotai 4.6 pav., apskaičiuokite:

(a) $x(t)$ skleidini kompleksinès eksponentės Furjè eilute.

(b) $x(t)$ skleidini trigonometrine Furjè eilute.

Ats. (a) $\frac{2 A}{j \pi}+\frac{A}{\pi} \sum_{m=-\infty}^{\infty} \frac{1}{2 m+1} e^{j(2 m+1) \omega_{0} t}$;

(b) $\frac{4 A}{\pi}+\frac{2 A}{\pi}\left(\sin \omega_{0} t+\frac{1}{3} \sin 3 \omega_{0} t+\frac{1}{5} \sin 5 \omega_{0} t+\cdots\right)$.

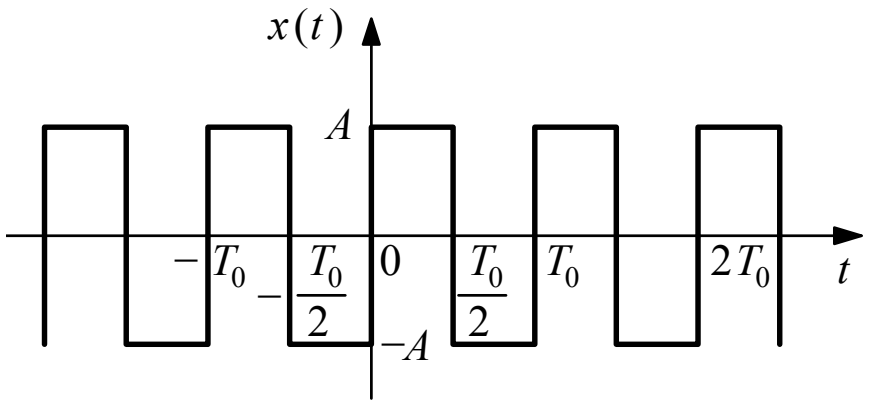

4.6 pav. 
4.10. Periodinè delta impulsų seka $\delta_{T_{0}}(t)$, pavaizduota 4.7 pav., apibrèžiama taip:

$$
\delta_{T_{0}}(t)=\sum_{k=-\infty}^{\infty} \delta\left(t-k T_{0}\right) .
$$

(a) Raskite $\delta_{T_{0}}(t)$ skleidini kompleksinès eksponentès Furjè eilute.

(b) Raskite $\delta_{T_{0}}(t)$ skleidinị trigonometrine Furjè eilute.

$$
\begin{aligned}
& \text { Ats. (a) } \frac{1}{T_{0}} \sum_{k=-\infty}^{\infty} e^{j k \omega_{0} t}, \quad \omega_{0}=\frac{2 \pi}{T_{0}} ; \\
& \text { (b) } \frac{1}{T_{0}}+\frac{2}{T_{0}} \sum_{k=1}^{\infty} \cos k \omega_{0} t, \quad \omega_{0}=\frac{2 \pi}{T_{0}} .
\end{aligned}
$$

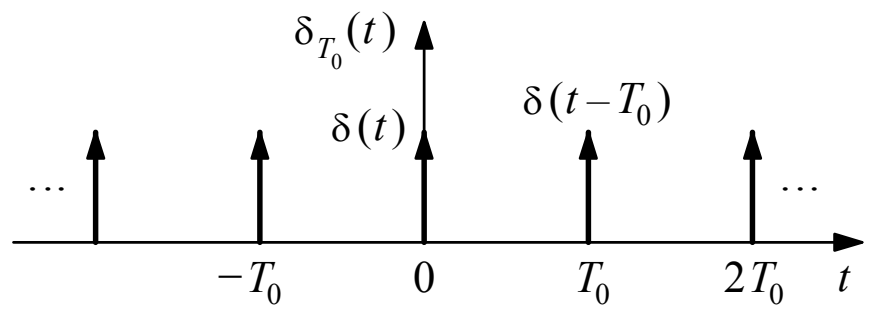

4.7 pav.

4.11. Duota trikampių impulsų seka $x(t)$, pavaizduota 4.8 pav. Taikydami diferencijavimo metodą, raskite:

(a) $x(t)$ skleidini kompleksinès eksponentès Furjè eilute;

(b) $x(t)$ skleidini trigonometrine Furjè eilute.

Ats. (a) $\frac{A}{2}-\frac{2 A}{\pi^{2}} \sum_{m=-\infty}^{\infty} \frac{1}{(2 m+1)^{2}} e^{j(2 m+1) \omega_{0} t}$; 
(b) $\frac{A}{2}-\frac{4 A}{\pi^{2}} \sum_{m=0}^{\infty} \frac{1}{(2 m+1)^{2}} \cos (2 m+1) \omega_{0} t$.

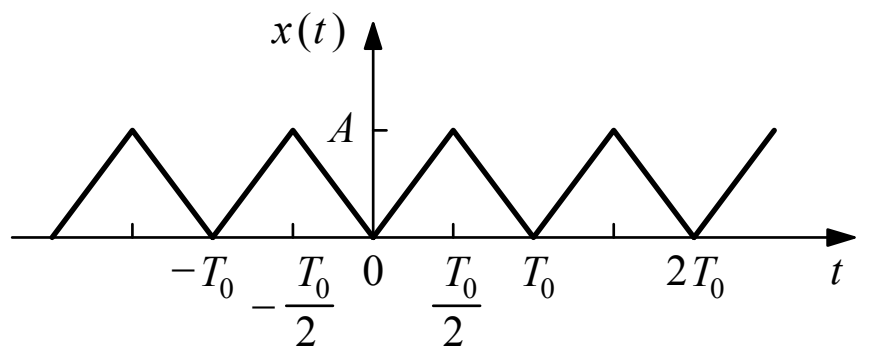

4.8 pav.

4.12. Duota trikampių impulsų seka $x(t)$, pavaizduota 4.9 pav. Taikydami diferencijavimo metodą, raskite $x(t)$ skleidini trigonometrine Furjè eilute.

Ats. $\frac{A}{2}+\frac{A}{\pi} \sum_{k=1}^{\infty} \frac{1}{k} \sin k \omega_{0} t, \quad \omega_{0}=\frac{2 \pi}{T_{0}}$.

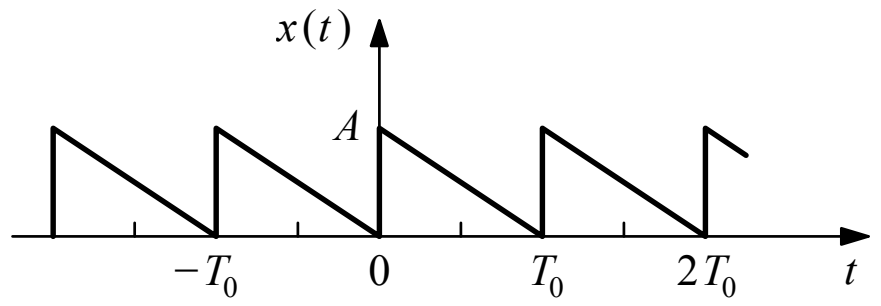

4.9 pav. 
4.13. Raskite ir nubraižykite šios periodinès impulsų sekos $x(t)$, pavaizduotos 4.10 pav., amplitudžiu spektrą, kai (a) $d=T_{0} / 4$ ir (b) $d=T_{0} / 8$.

Ats. (a) $\left|c_{k}\right|=\frac{A}{4}\left|\frac{\sin (k \pi / 4)}{k \pi / 4}\right|$; (b) $\left|c_{k}\right|=\frac{A}{8}\left|\frac{\sin (k \pi / 8)}{k \pi / 8}\right|$.

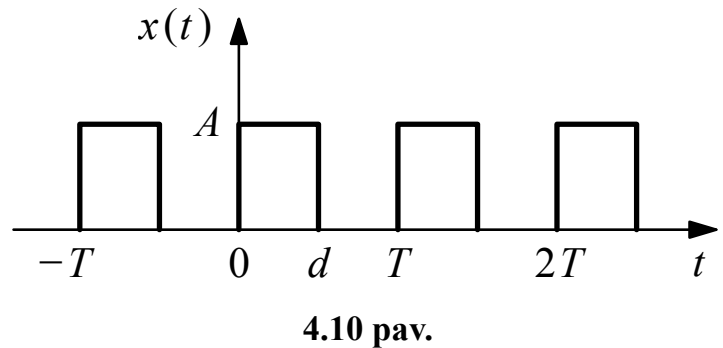

4.14. Tarkime, $\operatorname{kad} x_{1}(t)$ ir $x_{2}(t)$ - periodiniai signalai, kurių periodas $-T_{0}$, o jų skleidiniai kompleksinès eksponentės Furjè eilute yra tokie:

$$
x_{1}(t)=\sum_{k=-\infty}^{\infty} d_{k} e^{j k \omega_{0} t} \quad x_{2}(t)=\sum_{k=-\infty}^{\infty} e_{k} e^{j k \omega_{0} t} \quad \omega_{0}=\frac{2 \pi}{T_{0}} .
$$

Irodykite, kad signalas $x(t)=x_{1}(t) x_{2}(t)$ irgi yra periodinis su tuo pačiu periodu $T_{0}$, todèl ši signalą galima užrašyti taip:

$$
x(t)=\sum_{k=-\infty}^{\infty} c_{k} e^{j k \omega_{0} t} \quad \omega_{0}=\frac{2 \pi}{T_{0}},
$$

čia $c_{k}$ apibrèžiamas taip:

$$
c_{k}=\sum_{m=-\infty}^{\infty} d_{m} e_{k-m} .
$$


4.15. Raskite 4.11 pav. pavaizduoto stačiakampio impulso $x(t)$, apibrèžiamo kaip

$$
x(t)=\left\{\begin{array}{ll}
1 & |t|<a \\
0 & |t|>a
\end{array},\right.
$$

Furjè transformaciją.

$$
\text { Ats. } 2 a \frac{\sin \omega a}{\omega a} .
$$

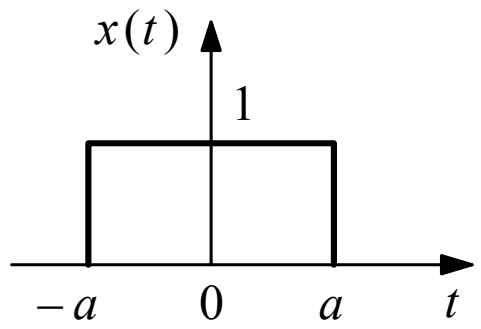

\subsection{1 pav.}

4.16. Raskite 4.12 pav. pavaizduoto signalo $x(t)$, apibrēžiamo kaip

$$
x(t)=\frac{\sin (a t)}{\pi t},
$$

Furjè transformacija.

$$
\text { Ats. } \begin{cases}1 & |\omega|<a, \\ 0 & |\omega|>a .\end{cases}
$$




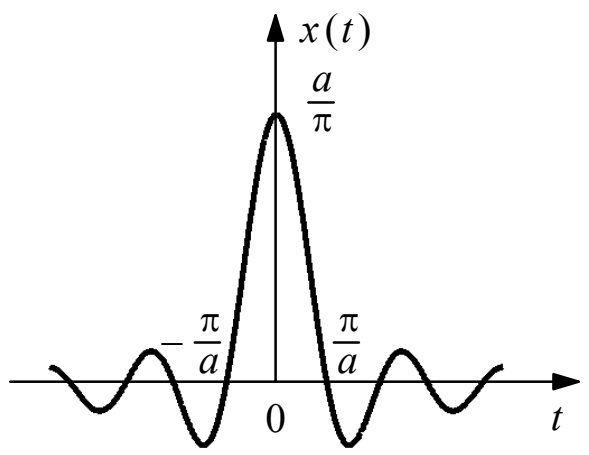

4.12 pav.

4.17. Raskite 4.13 pav. pavaizduoto signalo $x(t)$, apibrěžiamo kaip

$$
x(t)=e^{-a|t|} \quad a>0,
$$

Furjè transformaciją.

Ats. $\frac{2 a}{a^{2}+\omega^{2}}$.

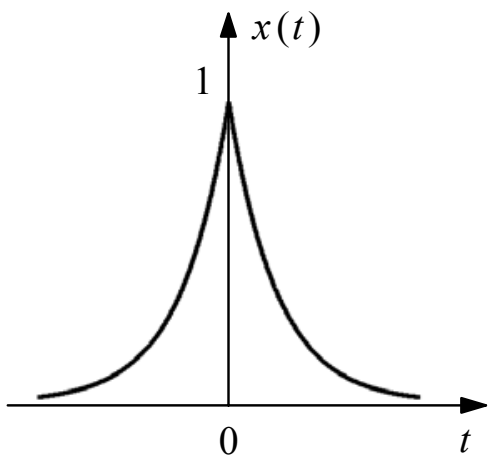

4.13 pav. 
4.18. Raskite 4.14 pav. pavaizduoto signalo $x(t)$, apibrěžiamo kaip

$$
x(t)=\frac{1}{a^{2}+t^{2}},
$$

Furjè transformacija.

$$
\text { Ats. } \frac{\pi}{a} e^{-a|\omega|} .
$$

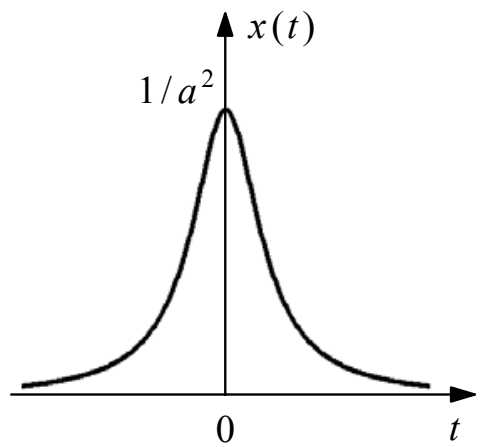

4.14 pav.

4.19. Raskite šių signalų Furjè transformacijas:
(a) $x(t)=e^{-j \omega_{0} t}$;
(b) $x(t)=\cos \omega_{0} t$;
(c) $x(t)=\sin \omega_{0} t$.

Ats.

$$
\begin{aligned}
& \text { (a) } 2 \pi \delta\left(\omega+\omega_{0}\right) \text {; (b) } \pi\left[\delta\left(\omega-\omega_{0}\right)+\delta\left(\omega+\omega_{0}\right)\right] \text {; } \\
& \text { (c) }-j \pi\left[\delta\left(\omega-\omega_{0}\right)-\delta\left(\omega+\omega_{0}\right)\right] .
\end{aligned}
$$

4.20. Raskite periodinio signalo $x(t)$, kurio periodas $-T_{0}$, Furjè transformaciją. 
Ats. $2 \pi \sum_{k=-\infty}^{\infty} c_{k} \delta\left(\omega-k \omega_{0}\right)$.

4.21. Raskite 4.7 pav. pavaizduotos periodinès delta impulsų sekos, apibrèžiamos kaip

$$
\delta_{T_{0}}(t)=\sum_{k=-\infty}^{\infty} \delta\left(t-k T_{0}\right)
$$

Furjè transformaciją.

$$
\text { Ats. } \omega_{0} \sum_{k=-\infty}^{\infty} \delta\left(\omega-k \omega_{0}\right) .
$$

4.22. Raskite šių signalų Furjè transformacijas:

(a) $x(t)=u(-t)$;

(b) $x(t)=e^{a t} u(-t), \quad a>0$.

Ats. (a) $\pi \delta(\omega)-\frac{1}{j \omega} ; \quad$ (b) $\frac{1}{a-j \omega}$.

4.23. Duotas realusis signalas $x(t)$, kuriam galima užrašyti:

$$
\begin{aligned}
& X(\omega)=\mathfrak{J}[x(t)]=A(\omega)+j B(\omega), \\
& x(t)=x_{l}(t)+x_{n}(t),
\end{aligned}
$$

čia $x_{l}(t)$ ir $x_{n}(t)$ - lyginè ir nelyginè $x(t)$ dedamosios. Irodykite, $\mathrm{kad}$

$$
x_{l}(t) \leftrightarrow A(\omega),
$$




$$
x_{n}(t) \leftrightarrow j B(\omega)
$$

4.24. Raskite signalo, aprašomo Gauso funkcija

$$
x(t)=e^{-a t^{2}}, \quad a>0,
$$

Furjè transformaciją.

Ats. $\sqrt{\frac{\pi}{a}} e^{-\omega^{2} / 4 a}$.

4.25. Duota tolydinè tiesinè stacionarioji sistema, aprašoma taip:

$$
\frac{d y(t)}{d t}+2 y(t)=x(t)
$$

Pasinaudodami Furjè transformacija, raskite sistemos atsaką $y(t)$ ¡ Ł šiuos signalus:

(a) $x(t)=e^{-t} u(t)$

(b) $x(t)=u(t)$.

Ats. (a) $\left(e^{-t}-e^{-2 t}\right) u(t)$; (b) $\frac{1}{2}\left(1-e^{-2 t}\right) u(t)$.

4.26. Duota sistema, aprašyta 4.25 uždavinyje. Sistemos iejjime veikia periodinè stačiakampių impulsų seka, pavaizduota 4.15 pav. Raskite sistemos atsako į ši signalą pirmosios ir trečiosios harmonikų amplitudes.

Ats. $\quad D_{1}=1,71 ; \quad D_{3}=0,22$. 


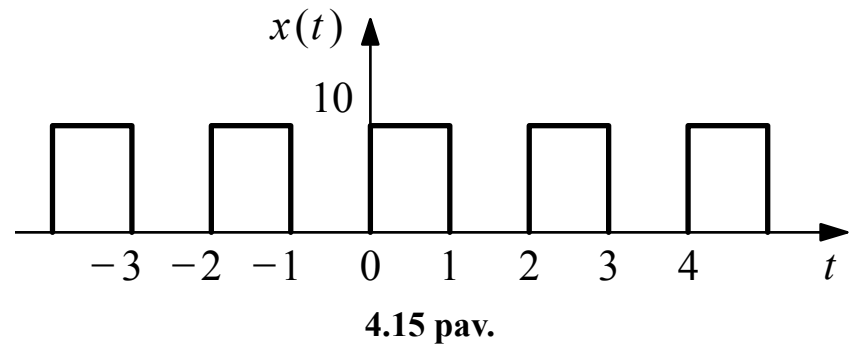

4.27. Idealioji fazès postūmio $-90^{\circ}$ kampu grandinè (žr. 4.16 pav.) pasižymi tokia dažnine charakteristika:

$$
H(\omega)= \begin{cases}e^{-j(\pi / 2)} & \omega>0 \\ e^{j(\pi / 2)} & \omega<0\end{cases}
$$

(a) Raskite grandinès impulsinę charakteristiką $h(t)$.

(b) Raskite grandinès atsaką $y(t)$ i bet kokị signalą $x(t)$.

(c) Raskite grandinès atsaką $y(t)$ i signalą $x(t)=\cos \omega_{0} t$.

Ats. (a) $\frac{1}{\pi t}$; (b) $\frac{1}{\pi} \int_{-\infty}^{\infty} \frac{x(\tau)}{t-\tau} d \tau$; (c) $\sin \omega_{0} t$.

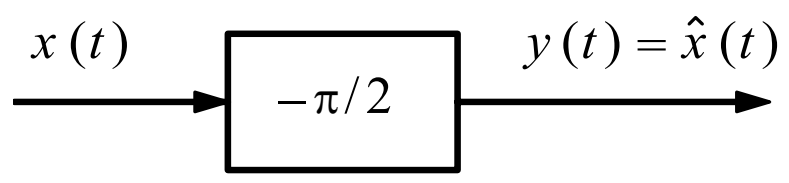

4.16 pav. 


\section{LITERATŪRA}

1. DUMBRAVA, V. Signalai ir sistemos. I dalis. Kaunas: Technologija, 2003. 285 p.

2. JACOB, J. M. Advanced AC Circuits and Electronics: Principles and Applications. New York: Thomson Delmar Learning, 2004. 455 p.

3. KARRIS, S. T. Signals and Systems with MATLAB ${ }^{\circledR}$ Computing and Simulink $^{\circledR}$ Modeling, $4^{\text {th }}$ ed. Fremont: Orchard Publications, 2008. $686 \mathrm{p}$.

4. LATHI, B. P. Signal Processing and Linear Systems. New York: Oxford University Press, $1998.850 \mathrm{p}$.

5. LIPEIKA, A. Signalu ir sistemu dažnine analizè. Vilnius: Technika, 2003. $157 \mathrm{p}$.

6. MINIOTAS, D. Elektros grandiniu analize. Vilnius: Technika, 2009. $260 \mathrm{p}$.

7. RAIŠUTIS, R.; TUMŠYS, O.; SVEIKATA, J. MATLAB grandiniu teorijoje. Kaunas: Technologija, 2007. 67 p.

8. SVEIKATA, J. Tiesiniu grandiniu teorija, 2-asis leidimas. Kaunas: Technologija, 2006. 272 p.

9. БАСКЕЙ,В.Я.;ВАСЮКОВ,В.Н.;ЗОТОВ,Л.Г.;МЕРЕНКОВ, В. М.; РАЗИНКИН, В. П.; ЯКОВЛЕВ, А. Н. Радиотехнические иепи и сигналы: задачи и задания. Москва: ИНФРА-М; Новосибирск: Изд-во НГТУ, 2003. 348 с.

10. РУМЯНЦЕВ, К. Е. Прием и обработка сигналов: сборник задач и упражнений. Москва: Издательский центр «Академия», 2006. 368 с. 